\title{
APLICAÇÃO DE NITROGÊNIO, FÓSFORO, POTÁSSIO, ADUBO ORGÂNICO E CALCÁRIO DOLOMÍTICO NA PRODUÇÃO DE SEMENTES DE GRAMA-BATATAIS (Daspalum notatum Flügge) EM LATOSSOL VERMELHO ESCURO
}

\author{
MARIA ESMERALDA SOARES PAYĀO DEMATTÊ
}

Orientador: Prof. Dr. HENRIQUE PAULO HAAG

\begin{abstract}
Tese apresentada à Escola Superior de Agricultura "Luiz de Queiroz", da Universidade de São Paulo, para obtenção do Título de Doutor em Agronomia. Área de Concentração: Solos e Nutrição de Plantas.
\end{abstract}

P I R A C I C A B A

Estado de São Paulo - Brasil

Agosto, 1983 
Meu pai me ensiniou que as sementes são tão fascinantes quanto as flores.

Dedico es te trabalho à sua memōria. 


\section{AGRADECIMENTOS}

Muitos deram sua contribuição a este trabalho. Expresso minha gratidão a todos, especialmente

ao Prof. Dr. Henrique Paulo Haag, meu orientador;

aos Professores Doutores Salim Simão, Godofredo César Vitti, Domingos Fornasieri Filho, Rubens Sader, Nelson Moreira de Carvalho, Manoel Evaristo Ferreira, Dilermando Perecin e Euclides Braga Malhe iros;

aos Senhores Josē Carregari e Gilberto Martins Silva;

ao Engenheiro Agrōnomo Jeremias Rodrigues de Mendonça e à Dra. Sidneide Manfredini;

a Lücia Helena Vasques, Carmem Maria Vilela, Valdir Apareci do Munhoz, Silvia Maria Lavecchia, Maria da Graça Silva Pereira, Maria Iolanda Claudino, Lázaro Abîlio Vantini, Nilton Loureiro e Araci Molnar Alon so;

a minha mãe e a meu marido. 


\section{INDICE}

\section{Pāgina}

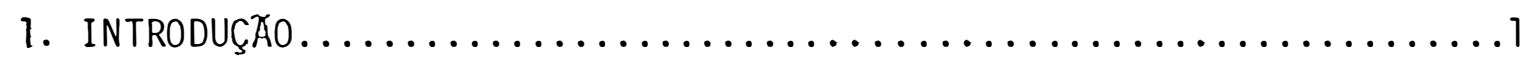

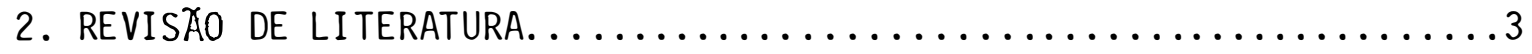

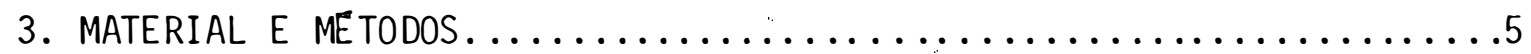

3.1. Localização, clima e solo..........................

3.2. Delineamento experimental e tratamentos................6

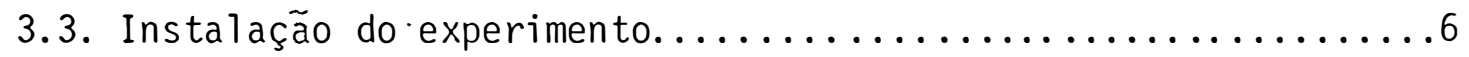

3.4. Análise quĩmica do solo na época do plantio..............6

3.5. Coletas de folhas e de sementes......................

3.6. Beneficiamento das sementes..................... 8

3.7. Testes de germinação......................... 8

3.8. Determinação de teores de nutrientes em folhas e sementes....9

3.9. Anālise estatística e avaliação dos resultados........... 9

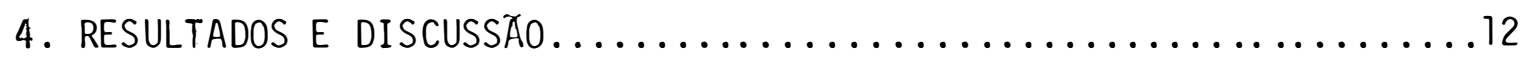

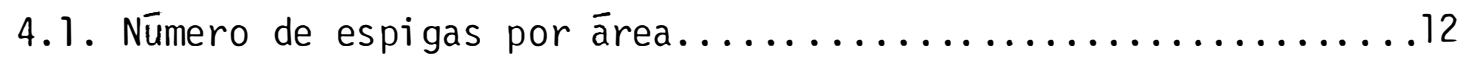

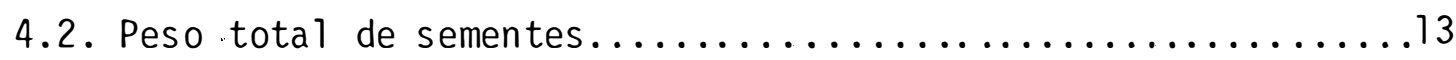

4.3. Peso de sementes puras.............................15

4.4. Relação entre peso de sementes puras e peso total de

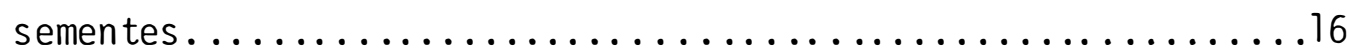

4.5. Peso de 1000 sementes puras.........................16

4.6. Peso total de sementes por espiga....................17

4.7. Peso de sementes puras por espiga.................... 18

4.8. Porcentagem de germinação das sementes.................18

4.9. Velocidade de emergēncia das pläntulas.................20

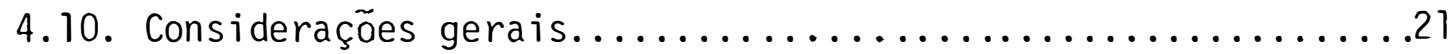

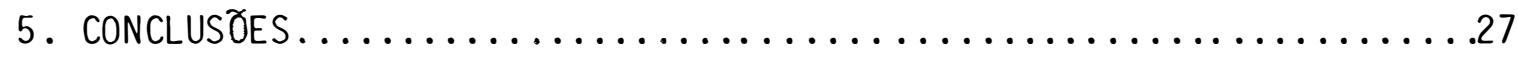

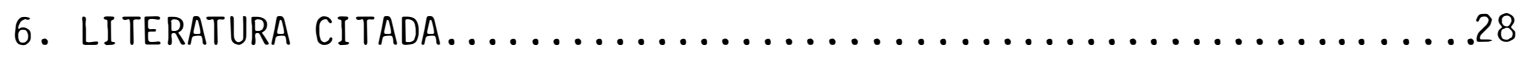
APENDICE 


\section{RESUMO}

Comparou-se a produção de sementes de grama-batatais em" Latossol Vermelho Escuro com ou sem adição de sulfato de amônio (4 g de $\mathrm{N} / \mathrm{m}^{2}$ ), superfosfato simples $\left(50 \mathrm{~g}\right.$ de $\left.\mathrm{P}_{2} \mathrm{O}_{5} / \mathrm{m}^{2}\right)$, cloreto de potássio (15 $\mathrm{g}$ de $\left.\mathrm{K}_{2} \mathrm{O} / \mathrm{m}^{2}\right)$, esterco curtido de equino (10 1itros $/ \mathrm{m}^{2}$ ) e calcārio dolomíti$\operatorname{co}\left(200 \mathrm{~g} / \mathrm{m}^{2}\right)$.

As produções foram avaliadas atravēs de nümero de espi gas por ārea, peso total de sementes, peso de sementes puras, relação entre peso de sementes puras e peso total de sementes, peso de 1000 semen tes puras, peso total de sementes por espiga, peso de sementes puras por espiga, porcentagem de germinação das sementes e velocidade de emergência das plāntulas. Foram determinados os teores de nitrogēnio, fósforo, potās sio, cālcio, magnésio, enxofre, boro, cobre, ferro, manganés e zinco na matéria seca de folhas e sementes.

Verificou-se que a produção de sementes, tanto em quantida de como em qualidade, foi influenciada pela nutrição mineral.

As porcentagens mais elevadas de carbono no solo estiveram associadas a maior quantidade e melhor qualidade das sementes produzidas.

As melhores produções de sementes corresponderam aos níveis mais baixos de fósforo, potássio, cālcio, magnésio, ferro e zinco nas folhas. Verificou-se serem importantes nas características avaliadas as seguintes relações entre teores de nutrientes nas folhas ou nas sementes: N/P, N/K, N/S, P/Ca, P/Mg, P/S, P/Fe, P/Zn, K/Ca, K/Mg, K/Ca+Mg , $\mathrm{K} / \mathrm{B}, \mathrm{Ca} / \mathrm{Mg}, \mathrm{Ca} / \mathrm{B}, \mathrm{Fe} / \mathrm{Mn}, \mathrm{Zn} / \mathrm{Cu}, \mathrm{Zn} / \mathrm{Fe}$ e $\mathrm{Zn} / \mathrm{Mn}$.

Nas maiores produções, as sementes apresentaram concentrações menores de nitrogênio, fósforo, boro e cobre, e mais elevadas de cāl cio. As sementes de melhor qualidade apresentaram maiores concentrações de cobre e zinco, e menores de potāssio è boro.

A aplicação de adubos ou calcārio dolomítico não melhorou significativamente a produção de sementes. 
SUMMARY

Application of nitrogen, phosphorus, potassium, manure and dolomitic lime as related to seed production of Paspalum notatum Flügge in a Dark Red La tosol.

Candidate: Maria Esmeralda Soares Payão Demattē

Adviser: Prof. Dr. Henrique Paulo Haag

Seed production of Paspalum notatum was compared with or without addition of $4 \mathrm{~g} / \mathrm{m}^{2}$ of $\mathrm{N}$ (as ammonium sulphate), $50 \mathrm{~g} / \mathrm{m}^{2}$ of $\mathrm{P}_{2} \mathrm{O}_{5}$, $15 \mathrm{~g} / \mathrm{m}^{2}$ of $\mathrm{K}_{2} \mathrm{O}$ (as potassium chloride), $10 \mathrm{l} / \mathrm{m}^{2}$ of horse manure and $200 \mathrm{~g} / \mathrm{m}^{2}$ of dolomitic lime in a Dark Red Latosol.

Seed production was evaluated through number of spikes, total weight, weight of pure seeds, relation between weight of pure seeds and total weight, weight of 1000 pure seeds, total weight per spike, weight of pure seeds per spike, seed germination percentage and seedlings emergence speed. Levels of $\mathrm{N}, \mathrm{P}, \mathrm{K}, \mathrm{Ca}, \mathrm{Mg}, \mathrm{S}, \mathrm{B}, \mathrm{Cu}, \mathrm{Fe}, \mathrm{Mn}$ and $\mathrm{Zn}$ in leaves and seeds dry matter were determined.

Quality and quantity of seeds were affected by mineral nutrition.

The highest values of $\mathrm{C} \%$ in soil were the best for seed yield and quality. The best seed production corresponded to the lowest levels of $\mathrm{P}, \mathrm{K}, \mathrm{Ca}, \mathrm{Mg}, \mathrm{Fe}$ and $\mathrm{Zn}$ in leaves. The relations $N / P, N / K, N / S$, $\mathrm{P} / \mathrm{Ca}, \mathrm{P} / \mathrm{Mg}, \mathrm{P} / \mathrm{S}, \mathrm{P} / \mathrm{Fe}, \mathrm{P} / \mathrm{Zn}, \mathrm{K} / \mathrm{Ca}, \mathrm{K} / \mathrm{Mg}, \mathrm{K} / \mathrm{Ca}+\mathrm{Mg}, \mathrm{K} / \mathrm{B}, \mathrm{Ca} / \mathrm{Mg}, \mathrm{Ca} / \mathrm{B}, \mathrm{Fe} / \mathrm{Mn}$, $\mathrm{Zn} / \mathrm{Cu}, \mathrm{Zn} / \mathrm{Fe}$ and $\mathrm{Zn} / \mathrm{Mn}$ in plants dry matter were important.

The highest seed yields corresponded to the lowest seed levels of $\mathrm{N}, \mathrm{P}, \mathrm{B}$ and $\mathrm{Cu}$, and to the highest seed levels of $\mathrm{Ca}$. The best seeds presented the highest levels of $\mathrm{Cu}$ and $\mathrm{Zn}$, and the lowest levels of $\mathrm{K}$ and $B$.

Seed production was not significantly improved by fertili zers or dolomitic lime application. 
1. INTRODUÇÃO

No planejamento paisagístico, um dos trabalhos mais importantes é o revestimento vegetal do solo, seja em pequenas āreas, onde obe dece, principalmente, a critérios estéticos, seja em grandes extensões, quando adquire significado de proteger o solo contra erosão e conservar seu potencial produtivo.

Para essa finalidade, a espécie mais utilizada na região centro-sul do Brasil tem sido Paspazum notatum Flügge (grama-batatais, grama-forquilha), pelas vantagens que esta gramínea perene apresenta: bela aparéncia; agressividade (TORRES, 1954), propiciando excelente cobertu ra do solo; grande capacidade de adaptação e resistēncia a condições ad versas, como fogo, seca, pisoteio, corte, baixas temperaturas, solos pobres (CORREA, 1926; OTERO, 1961 ; ARONOVICH et alii, 1973; HODGES e MARTIN, 1975; ALCÂNTARA e BUFARAH, 1979); melhoria das qualida des físicas do solo e de sua fertilidade (POLLOCK, 1956; NEYRA e DÖBEREINER, 1977); WEIER, 1980; DÖBEREINER e BODDEY, 1981); eficiēncia no contro 1e da erosão (ALENCAR, 1949; ROCHA, 1958; RICHARDSON e DISEKER, 1965) e na recuperação de solos degradados (LAL et alii, 1979). Sua excepcional rusticidade torna-a indicada para revestir campos de futebol (SOUZA, 1968).

A grama-batatais é tambēm planta forrageira, apresentando valor nutritivo médio e elevado teor de proteina. Estabelece-se em muitas situações desfavorāveis a outras forrageiras e, associada a leguminosas, proporciona boas pastagens. (OTERO, 1961). 
As sementes de grama-batatais nao germinam bem, constatando-se esse fato em todos os locais onde é cultivada.

Isso tem sido problema, principalmente, para a formação de pastagens, que abrangem āreas extensas. Para a formação de gramados, o plantio é feito por placas ou, em espaços muito pequenos, por mudas, prāticas essas que, além de serem mais caras, são, em certos casos, como em taludes ou terrenos acidentados, bastante difíceis. Para taludes, foi desenvolvida a técnica de hidrossemeadura, cuja dificuldade, para instalação de grama-batatais, estā justamente na baixa porcentagem de germinação de suas sementes.

Segundo TOLEDO et alii (1981), vārias causas podem contribuir para o baixo valor cultural das sementes de grama-batatais, destacan do-se, entre elas, a época inadequada de colheita e o fenōmeno de dorméncia.

A literatura mostra que problemas nutricionais podem influ enciar a qualidade das sementes produzidas por muitas espécies vegetais, incluindo as gramineas (CARVALHO e NAKAGAWA, 1980). Embora esse assunto não tenha sido suficientemente estudado em Paspalum spp., as informações disponīveis indicam que a má qualidade das sementes produzidas pela grama -batatais pode estar também associada à nutrição mineral.

Os objetivos deste trabalho foram:

a) comparar características de produção de sementes de grạ ma-batatais sem e com aplicação de nitrogênio, fósforo, potāssio, calcā rio dolomítico e matéria orgânica em Latossol Vermelho Escuro;

b) correlacionar as características de produção de semen tes com os teores de nitrogênio, fósforo, potāssio, cālcio, magnésio, enxofre, boro, cobre, ferro, manganês e zinco das folhas e das sementes das plantas estudadas, e com relações entre esses teores. 


\section{REVISÃO DE LITERATURA}

0 efeito de fertilizantes no desenvolvimento de Paspalum notatuon tem sido estudado em relação à produção de folhas, por causa de sua utilidade como planta forrageira. Foram conduzidos alguns trabalhos para observar a influência de nutrientes no enraizamento, mas a adubação de grama-batatais visando a produção de sementes tem sido muito pouco estudada, encontrando-se na literatura apenas a pesquisa de BURTON (1943 e 1944).

Trabalhando com dez gramineas forrageiras, BURTON (1943) verificou que grandes variações na quantidade e no balanço de fertilizan tes aplicados sobre solo pobre não influenciaram significativamente a porcentagem de flores de $P$. notatum que produziram sementes. Ele observou, entretanto, que a produção de sementes de todas as espécies, quando medida pelo número de inflorescéncias por unidade de área, foi, de modo geral, pou co influenciada por aplicações de fósforo e potássio, mas aumentou conside ravelmente quando se adicionou nitrogēnio à adubação fundamental de fósforo e potássio.

Em outro experimento, quando a produção de sementes de $P$. notatum cv. Paraguay foi comparada em parcelas não adubadas, adubadas com $560 \mathrm{~kg} / \mathrm{ha}$ de nitrato de sōdio $(16 \%$ de $\mathrm{N}$ ) e adubadas com $2471 \mathrm{~kg} / \mathrm{ha}$ de fertilizante NPK de fórmula 4-8-4, BURTON (1944) registrou os valores médios respectivos de 90,476 e $372 \mathrm{~kg} / \mathrm{ha}$ de sementes. Os tratamentos não tiveram efeito sobre a porcentagem de flores que produziram sementes, do mesmo mo- 
do que no trabalho anterior. A média do peso de 100 sementes variou de $0,260 \mathrm{~g}$ nas parcelas não adubadas para $0,263 \mathrm{~g}$ nas parcelas que receberam $\mathrm{N}$ e $0,249 \mathrm{~g}$ nas que receberam NPK.

De acordo com WHEELER e HILL (1957), as práticas estabeleci das para produção de plantas forrageiras para outras finalidades são, geralmente, satisfatōrias para produção de sementes. Entretanto, uma proporção maior de nitrogênio em relação às quantidades de fósforo e potássio normalmente aplicadas estimulam a produção de inflorescências. Esses autores informam que $P$. notatum produz bem sementes mesmo em solos relativamen te pobres, quando bem supridos de nitrogênio. Em condições ideais, pode-se esperar um aumento de $9 \mathrm{~kg}$ de sementes para cada $\mathrm{kg}$ de nitrogênio aplica do.

0 efeito do nitrogēnio na emissão de inflorescências de $P$. notatum, cujo número está diretamente correlacionado com sua produção de sementes (DEMATTE et alii, 1983 a), foi novamente observado em trabalhos recentes.

LAWRENCE (1975) relatou, em experimento de campo, que aplicações de nitrogēnio nas doses de 112 e $224 \mathrm{~kg} / \mathrm{ha}$ estimularam a produção de inflorescências do cultivar Wilmington Bahia.

PRATES (1977), comparando dois ecotipos nativos e o cultivar Pensacola de P. notatum, no Rio Grande do Sul, observou que somente as plantas que receberam adubação nitrogenada (150 e $300 \mathrm{~kg} / \mathrm{ha})$ floresceram, apresentando elevada porcentagem de colmos floriferos, nos intervalos de corte estudados ( 4,6 e 8 semanas, de novembro a março). Todas as plantas haviam recebido $200 \mathrm{~kg} / \mathrm{ha}$ de $\mathrm{P}_{2} \mathrm{O}_{5}$ e $200 \mathrm{~kg} / \mathrm{ha}$ de $\mathrm{K}_{2} \mathrm{O}$. Tanto as doses de $\mathrm{ni}$ trogênio como as de $\mathrm{P}_{2} \mathrm{O}_{5}$ e $\mathrm{K}_{2} \mathrm{O}$ aplicadas foram as que o autor considerou adequadas para a cultura da espécie quando se visa a produção de forragem, com base nas pesquisas feitas anteriormente.

Portanto, como tem sido observado na produção de sementes de outras gramineas forrageiras (JONES e. ROE, 1976; FAVORETTO, 1982), as maiores respostas de $P$. notatum resultaram da aplicação de nitrogênio, quan do as plantas estavam suficientemente nutridas de fósforo e potássio. 


\section{MATERIAL E METODOS}

\subsection{Localização, clima e solo}

0 experimento, conduzido com a espécie Paspaluon notatum Flügge (grama-batatais ou grama-forquilha), localizou-se na Faculdade de Ciēncias Agrārias e Veterinārias do Campus de Jaboticabal da Universidade Estadual Paulista (FCAVJ-UNESP), no município de Jaboticabal, SP.

As condições climáticas da região caracterizam o tipo Cwa de Köppen, isto é, clima subtropical úmido com estiagem de inverno. Na Ta bela $1\left(^{*}\right)$, são apresentados dados climáticos referentes ao local e ao periodo em que se cultivaram as plantas.

0 terreno que constituiu a ārea experimental tem dimensões de $14,40 \times 14,40 \mathrm{~m}^{2}$. Sua declividade aproximada é de $9 \%$, com exposição pa ra o norte, sendo bastante ensolarado. Foi utilizado anteriormente para experimentos com hortaliças, sempre recebendo adubação uniforme em toda a ārea; nos dóis anos anteriores a este estudo, esteve em repouso.

0 solo é classificado pela COMISSÃO DE SOLOS (1960) como Latossol Vermelho Escuro - fase arenosa e pertence, segundo levantamento detalhado feito por ALOISI e DEMATTE (1974), à Série Santa Tereza. Sua anālise granulométrica revelou, a $0-20 \mathrm{~cm}$ de profundidade, $31,3 \%$ de areia, $11,2 \%$ de 1 imo e $57,2 \%$ de argila, sendo classificado como solo argiloso, com densidade global de $1,48 \mathrm{~g} / \mathrm{cm}^{3}$.

${ }^{*}$ ) As Tabelas estão reunidas no Apéndice. 


\subsection{Delineamento experimental e tratamentos}

0 experimento foi delineado em fatorial $2^{5}$, com 32 tratamentos repetidos duas vezes, totalizando 64 parcelas. 0s tratamentos cons taram de aplicações de sulfato de amônio (aproximadamente $20 \%$ de $\mathrm{N}$ e $24 \%$ de $\mathrm{S}$ ), superfosfato simples (aproximadamente $16 \%$ a $18 \%$ de $\mathrm{P}_{2} \mathrm{O}_{5}$ ), cloreto de potássio (aproximadamente $60 \%$ de $\mathrm{K}_{2} \mathrm{O}$ ), adubo orgänico (esterco curtido de equino) e calcário dolomítico $(24,6 \%$ de $\mathrm{CaO}$ e $17,9 \%$ de Mg0, com poder relativo de neutralização total ou PRNT de 58,71), combinadas com ausēn cia dessas aplicações. Na Tabela 2, estão especificadas as quantidades de adubos e de calcário dolomítico aplicadas em cada tratamento.

Cada parcela teve dimensões totais de $1 \mathrm{~m} \times 1 \mathrm{~m}$, medindo, em sua parte ütil, $0,50 \mathrm{~m} \times 0,50 \mathrm{~m}$. As parcelas foram separadas por caminhos com $0,80 \mathrm{~m}$ de largura, providos de pequenos canais de drenagem.

\subsection{Instalação do experimento}

Em fevereiro de 1981, apōs aração, gradeação e destorroamento do solo, foi feita aplicação de calcārio dolomítico nas parcelas sorteadas. A aplicação de fertilizantes quīmicos e de adubo orgānico foi feita 60 dias mais tarde.

0 plantio de grama foi feito em agosto de 1981 , por mudas, medindo 4 a $6 \mathrm{~cm}$ de comprimento, em espaçamento de $10 \mathrm{~cm} \times 10 \mathrm{~cm}$, colocan do-se 25 mudas por parcela, na sua parte central, correspondente à ārea ütil.

As plantas foram inicialmente irrigadas, até o pegamento.

3.4. Anālise quīmica do solo na época do plantio.

Em agosto de 1981, imediatamente antes do plantio das mu 
das de grama, foram coletadas amostras de solo à profundidade de $0-20 \mathrm{~cm}$ em todas as parcelas. As amostras referentes às duas repetições do mesmo tratamento foram misturadas. Os dados obtidos na análise quîmica das 32 amostras resultantes, realizada pelo método descrito por. RAIJ e ZULLO (1977), encontram-se na Tabela 3.

\subsection{Coletas de folhas e de sementes}

Fizeram-se duas coletas de sementes, uma em dezembro de 1981 e outra em abril de 1982. O critério para estabelecer a época da pri meira coleta foi o recomendado por TOLEDO et alii (1981), is to é, quando havia mais de 5 espigas (inflorescéncias) por metro quadrado. A segunda coleta foi feita em estádio um pouco mais avançado, quando a maioria das sementes se apresentava com cor de palha, critério este utilizado por agricultores da região de Jaboticabal e recomendado por WHEELER e HILL (1957).

Nas duas épocas, coletaram-se todas as espigas na ārea útil da parcela, delimitada com o auxîlio de um quadrado de madeira medin do $0,50 \mathrm{~m} \times 0,50 \mathrm{~m}$.

Logo apōs a coleta de espigas, cortaram-se as folhas junto à sua inserção em todas as parcelas. As folhas cortadas na parte útil das parcelas foram lavadas em à gua corrente e secas em estufa a $70^{\circ} \mathrm{C}$ até peso constante, para posterior anālise de teores de nutrientes na matéria seca.

As espigas coletadas foram postas para secar sobre papel de jornal em galpão seco e ventilado, sendo as sementes, apōs o secamen to, separadas manualmente, ensacadas e armazenadas em cāmara seca com umi dade ralativa do ar de, aproximadamente, $35 \%$ a $45 \%$. 


\subsection{Beneficiamento das sementes}

Em dezembro de 1982, os diversos lotes de sementes foram limpos em assoprador ("seed blower" marca "General", fabricado em New Brunswick, New Jersey, U.S.A., utilizando-se a abertura 20 do aparelho durante 5 minutos para cada lote) para eliminação das sementes chochas e outras impurezas.

\subsection{Testes de germinação}

Foram feitos testes de germinação logo apōs a coleta, quando as sementes ainda não haviam sido beneficiadas, e apōs 14 meses de armazenamento em câmara seca, com as sementes limpas em assoprador (sementes puras). Portanto, os testes foram feitos em épocas diferentes para as sementes de cada coleta.

Realizaram-se os testes em períodos de 21 dias, em germinador a temperatura fixa de $30^{\circ} \mathrm{C}$ e com iluminação, colocando-se 100 semen tes de cada parcela em caixas plásticas transparentes e fechadas, com sub trato de papel de filtro umedecido. Foram feitos dois tipos de teste para cada parcela: germinação de sementes sem tratamento prévio em substrato umedecido com āgua e germinação de sementes tratadas com ācido: sulfürico concentrado durante 15 minutos, lavadas em àgua corrente e colocadas em substrato umedecido inicialmente com $\mathrm{KNO}_{3}(0,2 \%)$. Essas condições foram consideradas as melhores para realização dos testes em observações feitas previamente (DEMATTE et alii, 1983 b).

Após o término dos testes, as sementes que não germinaram foram submetidas a pressão com uma pinça. Para as que permaneceram inteiras, realizou-se o teste de tetrazōilo em solução a 0,1\% e 1\%, deixando as sementes seccionadas atravēs do embrião em imersão durante 4 horas em estufa a $35^{\circ} \mathrm{C}$. 
3.8. Determinação de teores de nutrientes em folhas e sementes

As folhas coletadas na ārea ūtil da parcela foram analisa das para determinação de teores de nutrientes na matéria seca, bem como se mentes de parcelas em que a quantidade colhida possibilitou a obtenção de amostras.

0 nitrogēnio, o fósforo e o boro foram determinados, respec tivamente, pelos métodos de semi-micro Kjeldahl, do àcido fosfovanadomolî́b dico e da curcumina (SARRUGE e HAAG, 1974). Para determinação de potāssio, cálcio, magnésio, cobre, ferro, manganês e zinco, utilizou-se a espectrofo tometria de absorção atômica (JORGENSEN, 1977). 0 enxofre foi determinado pelo método turbidimétrico (VITTI e RODELLA, 1982).

\subsection{Anālise estatística e avaliação dos resultados}

Os tratamentos foram comparados por anālise estatística para experimento fatorial $2^{5}$, transformando-se os dados referentes a nümero de espigas nas respectivas raĩzes quadradas, e dados de porcentagem em arco seno.

Foram calculados os coeficientes de correlação entre todas as características analisadas, e destas com os dados de análise do solo.

Estabeleceu-se como exigēncia mīnima para avaliação dos resultados a significáncia ao nível de $5 \%$ de probabilidade para os valores de $F$ e $t$ calculados.

Os resultados foram avaliados através da anālise das seguin tes características:
a) nūmero de espigas por ārea;
b) peso total de sementes (peso antes do beneficiamento);
c) peso de sementes puras (peso depois da limpeza em asso-

prador) ; 
d) relação entre peso de sementes puras e peso total de sementes;

e) peso de 1000 sementes puras;

f) peso total de sementes por espiga;

g) peso de sementes puras por espiga;

h) porcentagem de germinação de sementes não tratadas, em substrato umedecido com àgua;

i) porcentagem de germinação de sementes tratadas com ácido sulfürico, em substrato umedecido com $\mathrm{KNO}_{3}$;

j) velocidade de emergência de plāntulas originadas de sementes não tratadas, em substrato umedecido com água;

k) velocidade de emergencia de plāntulas originadas de sementes tratadas com ácido sulfúrico, em substrato umedecido com $\mathrm{KNO}_{3}$;

1) teores de nitrogênio, fósforo, potássio, cálcio, magné sio, enxofre, boro, cobre, ferro, manganès e zinco na matéria seca de fothas e sementes;

m) as seguintes relações entre teores de nutrientes na maté ria seca de folhas e de sementes: N/P, N/K, N/S, P/Ca, P/Mg, P/S, P/Fe, $\mathrm{P} / \mathrm{Zn}, \mathrm{K} / \mathrm{Ca}, \mathrm{K} / \mathrm{Mg}, \mathrm{K} / \mathrm{Ca}+\mathrm{Mg}, \mathrm{K} / \mathrm{B}, \mathrm{Ca} / \mathrm{Mg}, \mathrm{Ca} / \mathrm{B}, \mathrm{Fe} / \mathrm{Mn}, \mathrm{Zn} / \mathrm{Cu}, \mathrm{Zn} / \mathrm{Fe}$ e $\mathrm{Zn} / \mathrm{Mn}$.

A velocidade de emergencia das plāntulas foi calculada pela förmula de MAGUIRE (1962):

contagem;

$$
\begin{aligned}
& V e=N_{1} D_{1}+N_{2} D_{2}+\ldots N_{n} D_{n} \text {, onde } \\
& V e=\text { indice de velocidade de emergência; } \\
& N_{1}=\text { número de plāntulas normais emersas no primeiro dia de }
\end{aligned}
$$

$D_{1}=$ nūmero de dias transcorridos des de a instalação do tes te até o primeiro dia de contagem;

$\mathrm{N}_{2}=$ número de plântulas normais emersas entre o primeiro e o segundo dias de contagem;

$\mathrm{D}_{2}=$ número de dias transcorridos desde a instalação do tes te até o segundo dia de contagem; 
$N_{n}=$ nūmero de plāntulas normais emersas entre 0 penūtimo e o ūltimo dias de contagem;

$D_{n}=$ número de dias transcorridos desde a instalação do tes te até o ūltimo dia de contagem. 
4. RESULTADOS E DISCUSSÃO

Nas Tabelas de 4 a $22\left({ }^{*}\right)$, apresentam-se resultados obti dos na anālise de experimento fatorial. A Tabela 23 reúne as relações entre teores foliares de nutrientes que não se mostraram importantes para a produção de sementes de grama-batatais (N/P, N/K, N/S, P/Ca, P/S, P/Fe, $\mathrm{P} / \mathrm{Zn}, \mathrm{K} / \mathrm{Ca}, \mathrm{K} / \mathrm{B}, \mathrm{Zn} / \mathrm{Cu}$ e $\mathrm{Zn} / \mathrm{Mn}$ ) ou que não variaram significativamente nos diferentes tratamentos (P/Mg, $\mathrm{Ca} / \mathrm{B}, \mathrm{Fe} / \mathrm{Mn}$ e $\mathrm{Zn} / \mathrm{Fe})$, especificando suas médias e intervalos de variação. Na Tabela 24, encontram-se as médias de relações entre teores de nutrientes nas sementes e seus intervalos de variação.

As Tabelas 25 e 26 mostram os coeficientes de correlação entre as características de produção de sementes, que serão analisadas a seguir. Correlações significativas entre características de produção de sementes e composição quîmica do solo e das plantas são apresentadas nas Tabelas de 27 a 36.

\subsection{Nūmero de espigas por ārea}

0 número de espigas por ārea mostrou ser um bom índice da quantidade de sementes produzidas (Tabelas 25 e 26), apoiando o critério utilizado por BURTON (1943) para medir a produção de sementes de Paspalum notatum e concordando com afirmações de WHEELER e HILL (1957) e LAWRENCE (1975).

${ }^{*}$ As Tabelas estão reunidas no Apêndice. 
$\mathrm{Na}$ segunda coleta, o nūmero de espiga foi tambēm indicativo da qualidade de sementes (Tabela 26), observando-se tendēncia de, à me dida que as espigas se tornavam mais numerosas por unidade de ārea, haver prejuízo na qualidade de suas sementes.

Houve interação significativa entre potāssio e adubo orgâ nico na produção de espigas da segunda coleta (Tabela 4): quando não se aplicou adubo orgānico, a média do número de espigas por parcela variou de 2,78 (sem aplicação de potāssio) para 2,92 (com aplicação de potās sio); quando foi aplicado adubo orgānico, a variação ocorreu em sentido contrārio, de 2,89 (sem aplicação de potássio) para 2,79 (com aplicação de potāssio).

A relação Ca/Mg na matéria seca de folhas cortadas na segunda coleta, correlacionada positivamente com o nümero de espigas por ārea (Tabela 27), foi maior sem aplicação de adubo orgānico (média de 1,08 ) do que com aplicação de adubo orgānico (média de 0,98), como mostram os dados da Tabela 22, variando tambēm em função da interação entre nitrogênio e potāssio, com médias, sem aplicação de potāssio, de 0,94 e 1,08 respectivamente sem e com aplicação de sulfato de amōnio, manifestan do-se, neste caso, o efeito benéfico do nitrogēnio na produção de inflo rescências descrito na literatura; com aplicação de potássio, as médias variaram de 1,10 para 0,99 respectivamente sem e com aplicação de sulfato de amōnio. O efeito da adição de esterco no decréscimo da relação $\mathrm{Ca} / \mathrm{Mg}$ deveu-se principalmente ao aumento da concentração foliar de magnésio que a aplicação desse adubo proporcionou (Tabela 15).

\subsection{Peso total de sementes.}

$\mathrm{Na}$ primeira coleta, houve interação significativa entre fósforo e potássio na produção total de sementes por parcela (Tabela 5 ). Quando não se aplicou potássio, a adição de adubo fosfatado provocou de créscimo da média de peso total de sementes por parcela $(2,49 \mathrm{~g})$ em compa ração com a do tratamento que não recebeu fósforo $(3,20 \mathrm{~g})$. Quando foi 
aplicado potāssio, a média das parcelas que não receberam fósforo $(2,57 \mathrm{~g})$ foi menor do que a das que receberam fósforo $(2,90 \mathrm{~g})$.

$\mathrm{Na}$ segunda coleta, houve interação significativa entre aplicação de sulfato de amōnio e calcário dolomítico na produção total de sementes por parcela (Tabela 5). Sem calagem, a média de produção foi $7,33 \mathrm{~g}$ nas parcelas que não receberam sulfato de amōnio e 9,65 g nas que receberam sulfato de amōnio. Quando a calagem foi feita, as médias foram de $7,97 \mathrm{~g}$ e $7,05 \mathrm{~g}$ respectivamente nas parcelas sem e com aplicação de sulfato de amônio.

Nesta caracterîstica, acentuou-se a tendēncia que indica efeito prejudicial da absorção de magnésio nas quantidades mais elevadas sobre a produção de sementes da segunda coleta (Tabela 28). As concentrações de magnésio na matéria seca de folhas (Tabela 15) aumentaram com a plicação de adubo orgânico ou fosfatado.

Tem sido observado efeito sinergistico entre nitrogénio e magnésio quando o nitrogênio é absorvido como ion nitrato (Shear e Barrows, citados por COUTINHO et alii, 1979). Entretanto, a redução na absorção de magnésio em plantas que receberam nitrogênio amoniacal é bastan te conhecida, tanto em solos como em solução nutritiva (VIETS et alii , 1964; WILCOX et alii, 1973), sendo esse efeito também constatado em gramî neas forrageiras (GRUNES et alii, 1970). Isso pode explicar a diminuição das concentrações foliares de magnésio causada pela adição de sulfato de amōnio, contrapondo-se ao aumento dessas concentrações quando se apli cou adubo orgânico (Tabela 15).

$\mathrm{Na}$ primeira coleta, houve efeito da interação entre potāssio e adubo orgânico na concentração foliar de magnésio (Tabela 15): sem aplicação de esterco, a adição de potāssio fez diminuir a concentração fo liar de magnésio, evidenciando-se o conhecido antagonismo entre potássio e magnésio (EPSTEIN, 1975); quando foi aplicado esterco, a concentração foliar de magnésio elevou-se com aplicação de potāssio. Na segunda cole ta, houve interação significativa entre aplicação de sulfato de amónio e 
calagem na concentração foliar de magnésio: sem calagem, a concentração fo liar de magnésio foi menor quando se aplicou sulfato de amónio; com cala gem, a aplicação de sulfato de amónio provocou aumento na concentração foliar de magnésio. A verificação dessa ūltima tendência apōia o comentário sobre a interação entre sulfato de amónio e calcário dolomítico na produ ção total de sementes da segunda coleta (Tabela 5) jā feito neste îtem, in dicando que as maiores concentrações foliares de magnésio estiveram asso ciadas às menores produções de sementes.

\subsection{Peso de sementes puras}

Esta característica foi mais indicativa da quantidade do que da qualidade das semente produzidas (Tabelas 25 e 26).

Na primeira coleta, houve interação significativa entre as aplicações de sulfato de amônio e adubo orgānico na produção de sementes puras (Tabela 5). Sem esterco, a adição de nitrogênio fez diminuir o peso de sementes puras por parcela (médias de $0,40 \mathrm{~g}$ e $0,21 \mathrm{~g}$ sem e com sulfato de amônio respectivamente). Aplicando-se esterco, o peso de sementes puras por parcela cresceu com a adição de sulfato de amōnio (médias de $0,24 \mathrm{~g}$ e $0,34 \mathrm{~g} \mathrm{sem} \mathrm{e} \mathrm{com} \mathrm{sulfato} \mathrm{de} \mathrm{amōnio} \mathrm{respectivamente).} \mathrm{E} \mathrm{possivel} \mathrm{que,quan}$ do não houve os benefícios da adição de esterco em termos de suprimento de diversos nutrientes, a aplicação de nitrogēnio tenha provocado o aumento da proporção de sementes mais leves, eliminadas pelo assoprador, coinci dindo com o fato relatado por LAMBERT (1965) para Phleum pratense.

$\mathrm{Na}$ segunda coleta, houve efeito das interações entre aplica ção de sulfato de amônio e calagem, e de potássio e adubo orgānico (Tabela $5)$. Sem calagem, as médias de peso de sementes puras por parcela variaram de 4,88 g para 6,86 g respectivamente sem e com aplicação de sulfato de amónio; com calagem, decresceram de $5,18 \mathrm{~g}$ para $4,52 \mathrm{~g}$ quando se aplicou 0 sulfato de amônio. Para a segunda interação, quando não de adicionou ester co, as médias foram de 4,89 g sem aplicação de potássio e 5,70 g com adubą 
ção potássica; aplicando-se esterco, as médias decresceram de $6,20 \mathrm{~g}$ para 4,60 g respectivamente sem e com adubação potāssica. Novamente, manifesta-se a interação entre as adubações potássica e nitrogenada verificada para as caracteristicas discutidas nos dois $i$ tens anteriores.

\subsection{Relação entre peso de sementes puras e peso total de sementes}

Também esta característica foi mais indicativa da quantidade do que da qualidade das sementes, principalmente na segunda coleta (Tabelas 25 e 26).

Houve interação significativa entre calagem e aplicação de adubo orgânico nesta relação (Tabela 6). Sem calagem, a relação aumentou (de 0,10 para 0,12) com aplicação de adubo orgānico; com calagem, as mé dias decresceram de 0,15 para 0,09 respectivamente sem e com adubo orgânico.

\subsection{Peso de 1000 sementes puras.}

Esta è uma característica importante para avaliar produção de sementes de grama-batatais, porque foi indicadora da qualidade das sementes, correlacionando-se com seu poder de germinação e seu vigor (Tabela 25). A melhor qualidade demonstrada por sementes maiores ou mais pesadas é fato comum (CARVALHO e NAKAGAWA, 1980).

$\mathrm{Na}$ primeira coleta, houve interação significativa entre aplicações de fósforo e potássio afetando o peso de 1000 sementes (Tabela 6). Sem aplicação de potássio, os pesos médios de 1000 sementes variaram de 2,79 g (sem aplicação de fósforo) para $2,65 \mathrm{~g}$ (com aplicação de fósfo ro); aplicando-se potāssio, as médias cresceram de 2,58 g para 2,84 g respectivamente sem e com aplicação de fósforo.

Também na primeira coleta, o peso de 1000 sementes correlacionou-se negativamente com as concentrações de potássio e cālcio e as re- 
lações $\mathrm{K} / \mathrm{Mg}$ e $\mathrm{Ca} / \mathrm{Mg}$ das folhas (Tabela 31 ).

Para o potássio e a relação $\mathrm{K} / \mathrm{Mg}$ das folhas, as interações entre fósforo e adubo orgânico foram significativas (Tabelas 13 e 22) por que, sem adubo orgānico, os valores aumentaram com aplicação de fós foro e, com adubo orgânico, decresceram com aplicação de fósforo. As concentra ções foliares de potássio variaram ainda em função da interação entre a plicações de potássio e adubo orgânico (Tabela 13): sem adubo orgânico, di minuiram com aplicação de potássio; com adubo orgânico, aumentaram com aplicação de potássio. Este fato é semelhante ao verificado em relação à concentração foliar de magnésio na mesma coleta (Tabela 15).

A concentração foliar de cālcio aumentou com aplicação de esterco (Tabela 14) e, assim como a relação $\mathrm{Ca} / \mathrm{Mg}$ das folhas (Tabela 22), variou em função da interação entre aplicações de sulfato de amōnio e cal cário, aumentando com a adição de sulfato de amōnio em auséncia de cala gem e diminuindo, em presença de calagem, com adição de sulfato de amó nio. A relação $\mathrm{Ca} / \mathrm{Mg}$ foliar também foi influenciada pela interação entre as adubações fosfatada e potássica, aumentando com aplicação de fósforo quando não se adicionou potāssio e, com adição de potássio, diminuindo com a adubação fosfatada.

$\mathrm{Na}$ segunda coleta, houve efeito da interação entre aplicações de fósforo e adubo orgânico no peso de 1000 sementes puras: sem adubo orgânico, as médias desses pesos cresceram de 2,55 g para 2,58 g com adição de fósforo; com adubo orgānico, a adição de fósforo fez diminuir os pesos médios de 2,70 g para 2,49 $\mathrm{g}$.

\subsection{Peso total de sementes por espiga}

Esta característica referiu-se tanto à quantidade como à qualidade das sementes produzidas (Tabelas 25 e 26). As sementes de meThor qualidade foram obtidas nas parcelas que apresentaram os menores pesos totais de sementes por espiga. 
Na primeira coleta, o peso total de sementes por espiga foi influenciado pela interação entre as aplicações de fósforo e potássio (Tabela 7): sem adubação potássica, os valores foram menores com aplicação de fósforo (média de $0,12 \mathrm{~g}$ ) do que sem aplicação de fósforo (média de $0,14 \mathrm{~g})$; com adubação potássica, as médias cresceram de $0,11 \mathrm{~g}$ para $0,14 \mathrm{~g}$ quando se aplicou fósforo.

Na segunda coleta, o peso total de sementes por espiga tendeu a ser maior quando as concentrações foliares de cálcio eram menores (Tabela 32). As concentrações foliares de cálcio, por sua vez, variaram em função da interação entre as adubações com sulfato de amōnio e cloreto de potássio, aumentando, em ausência de adubação potássica, com aplicação de sulfato de amónio e, quando se adicionou potássio, diminuindo com aplicação de sulfato de amónio.

\subsection{Peso de sementes puras por espiga}

A qualidade das sementes melhorou com o aumento do peso de sementes puras por espiga na primeira coleta (Tabela 25), o que não se verificou na segunda coleta (Tabela 26).

0 peso de sementes puras por espiga, na primeira coleta, foi afetado pelas interações entre aplicações de sulfato de amōnio e esterco, e entre calagem e aplicação de esterco (Tabela 7). Sem adubo orgānico,apli cação de sulfato de amōnio diminuiu as médias de peso de sementes puras por espiga de $0,02 \mathrm{~g}$ para $0,01 \mathrm{~g}$ e a calagem aumentou as médias de $0,01 \mathrm{~g}$ para 0,02 g; com adubo orgânico, não houve essa variação (média de 0,01g).

\subsection{Porcentagem de germinação das sementes.}

A porcentagem de germinação das sementes (Tabelas 8 e 9 ) foi, de modo geral, muito baixa, como tem sido relatado (ALCÂNTARA e BU FARAH, 1979). Nos testes feitos logo apōs as coletas, não houve germinação 
para a quase totalidade das sementes, verificando-se alta porcentagem de sementes chochas, pois ainda não havia sido feita a limpeza com assopra dor.

Mesmo apōs terem sido armazenadas durante 14 meses em câmara seca, periodo que TOLEDO et alii (1981) consideram suficiente para perda completa de dormência, as sementes obtidas na primeira coleta germina ram melhor e mais rapidamente com escarificação com ácido sulfúrico e apli cação de $\mathrm{KNO}_{3}$, provavelmente porque foram colhidas cedo demais, quando a maioria ainda não estava madura. Para as sementes da segunda coleta, esse tratamento adicional com ácido sulfúrico fez cair para valores próximos de zero a porcentagem de germinação, exceto para alguns tratamentos onde se aplicou fósforo ou calcário dolomítico (Tabela 9), embora a grande varia ção verificada neste caso não permita considerar esta ocorrência significa tiva.

Ao final de todos os testes de germinação realizados apōs o armazenamento de 14 meses, verificou-se, pelo teste de tetrazōlio, que nenhuma das sementes que haviam permanecido duras teve seu embrião inteira mente colorido, sendo que a maioria delas não exibiu nenhuma coloração ver melha. Isso indica que as sementes que não germinaram estavam, em sua maio ria, mortas.

Na primeira coleta, a porcentagem de germinação das semen tes tratadas com ácido sulfūrico variou em função das interações entre aplicações de fósforo e potássio e entre potássio e calagem (Tabela 9). Sem adubação potássica, aplicação de fósforo provocou diminuição das médias de porcentagem de germinação de 29,5 para 16,8; com aplicação de potássio, as porcentagens cresceram, com aplicação de fósforo, de valores médios de 20,9 para 41,6. Sem calagem, a adubação potássica diminuiu os valores médios de $24,6 \%$ para 18,3\%; com calagem, a adubação potássica elevou os valores médios de $21,7 \%$ para $44,9 \%$.

A porcentagem de germinação, na primeira coleta, correlacio nou-se negativamente com diversos teores foliares (Tabelas 34 e 36), al - 
guns jā comentados; entre eles, os teores foliares de ferro e zinco, que diminuiram com aplicação de fósforo (Tabelas 19 e 21). Portanto, sob es te aspecto, a aplicação de fósforo beneficiou a qualidade das sementes da prí meira coleta.

0 efeito do fósforo na diminuição da absorção de ferro ē bastante conhecido. Ensaios conduzidos em diversas culturas têm apontado o fósforo como um dos principais responsáveis pelo aparecimento de clorose férrica. WATANABE et alii (1965) verificaram o surgimento de sintomas de carência de ferro na cultura de mi tho quando a relação $P / F e$ era maior que 60. MILLER et alii (1959) sugerem que a possĩvel causa dessa deficiéncia ē a redução do ferro disponível e sua posterior precipitação no meio.

0 efeito antagōnico do fósforo na absorção de zinco foi observado em diversas culturas, inclusive gramīneas (CHAUDHRY e SHARIF, 1974). MALAVOLTA e LOPEZ GOROSTIAGA (1974), trabalhando com cevada, verifí caram que a presença de fosfato causa inibição não competitiva na absorção de zinco, precipitação do zinco na superfície das raīzes, dependendo do $\mathrm{pH}$ do meio, diminuição do transporte do zinco para a parte aérea e diluição no teor de zinco, causada pelo desenvolvimento da planta em resposta à adi ção de fósforo.

\subsection{Velocidade de emergência das pläntulas}

Esta característica, considerada boa para avaliação de vigor das sementes (MAGUIRE, 1962), também variou em função da interação entre as aplicações de fósforo e potássio na primeira col̉eta, acompanhando a tendência da porcentagem de germinação. Observou-se efeito adverso da absorção de potássio nas concentrações mais elevadas, possivelmente tendo como conseqüência efeito tóxico do boro (Tabelas 17, 35 e 36).

REEVE e SHIVE (1944) e QUELLETTE (1963) observaram que al tas doses de potássio causaram elevação no teor de boro solūvel na plan ta, o que poderia agravar os efeitos tóxicos do boro. Esse aumento na ab- 
sorção de boro pode ser explicado como uma diminuição na atividade do cálcio como efeito do antagonismo entre potássio e cálcio (SARRUGE, 1968; HADAS e HAGIN, 1972). HADAS e HAGIN (1972) sugeriram que também no solo ocor re essa interação: altas concentrações de potássio trocável podem criar condições mais favoráveis para adsorção de boro.

\subsection{Considerações gerais}

Houve maior produção de sementes na segunda coleta (Tabe las 4 e 5). Pode-se atribuir essa diferença ao fato de que a segunda coleta foi feita em fase mais avançada de formação de sementes do que a primei ra, uma vez que as condições climáticas em que as inflorescências se forma ram variaram pouco (Tabela 1). Verifica-se também melhor desempenho das sementes da segunda coleta (Tabelas 8 e 10), quando não foi feito nenhum tratamento para quebra de dormência.

Pelo exame das Tabelas 27, 28, 29 e 36, verifica-se que a aplicação de calcário dolomítico, com conseqüente aumento nas concentra ções de cálcio e magnésio no solo (Tabela 3), foi prejudicial à quantidade de sementes produzidas, mas apresentou efeito benéfico no desempenho de se mentes tratadas com ácido sulfúrico e $\mathrm{KNO}_{3}$, constatando-se, neste caso, in fluência também do pH do solo (Tabela 36). A influência benéfica de aplica ções de cálcio e magnésio na produção de sementes de diversas plantas, inclusive gramineas, é destacada por TURKIEWICZ (1976).

Observa-se que as maiores produções de sementes e as sementes de melhor qualidade foram obtidas nas parcelas que apresentavam as mai ores porcentagens de carbono no solo e, portanto, provavelmente os maiores teores de matéria orgánica (Tabelas de 27 a 31). Os dados da Tabela 3 mostram que a adição de esterco não provocou aumento nas porcentagens de carbono no solo. Alguns trabalhos têm demonstrado que a porcentagem de carbono no solo não aumenta sensivelmente com aplicação de esterco, embora ocor ra, nessas condições, elevação na soma de bases (GROHMANN et alii, 1966) . 
0 efeito da adição de esterco no aumento da concentração de cālcio e magnē sio das folhas (Tabelas 14 e 15) pode ser devido à liberação de nitrogênio pelo adubo orgānico, que teria concorrido para maior absorção de cálcio e magnésio (WHITE et alii, 1965; Shear e Barrows, citados por COUTINHO et alii, 1979).

De modo geral, o decréscimo da disponibilidade da maioria dos nutrientes no período em que se formaram as sementes da segunda coleta, demonstrado pela diminuição dos teores foliares, não se refletiu em dimi nuição dos teores desses nutrientes nas sementes (Tabelas 11 a 21).

AUSTIN (1972) afirma que as deficiencias minerais afetam predominantemente o número de sementes produzidas mas, a não ser que a deficiência seja severa, têm efeito menor sobre a composição da semente.

Assim como foi observado em arroz (FORNASIERI FILHO, 1982), os teores de nitrogênio, potāssio, cālcio, magnēsio e manganēs fo ram maiores na matéria seca de folhas que na de sementes, e os teores de fósforo e zinco foram mais altos na matéria seca de sementes em comparação com a de folhas. No presente estudo, a matéria seca de folhas apresentou teores mais elevados de enxofre que a de sementes e houve maior acumulação de boro nas sementes que nas folhas. A distribuição de cobre e ferro foi variāvel com a época das coletas (Tabelas de 11 a 21).

A correlação negativa entre produção de sementes e concen tração de nitrogênio nas sementes (Tabelas 27, 28 e 29) jā foi anteriormen te verificada por LAMPETER et alii (1965) para outras gramineas forragei ras. Esses autores afirmaram que, para altas produções. de sementes, ē adequado baixo teor de nitrogênio nas sementes.

Quanto aos demais teores de nutrientes nas sementes, as maiores produções de sementes corresponderam aos teores mais elevados de potássio, cálcio, enxofre e manganês, e mais baixos de fósforo, boro e cobre (Tabelas 27, 28, 29, 30 e 32). As sementes de melhor qualidade apresen taram teores mais elevados de fósforo, cobre, ferro e zinco, e mais baixos 
de potássio e boro (Tabelas 31,34, 35 e 36), embora, no caso do fósforo e do ferro, as correlações fossem verificadas apenas para o peso de 1000 sementes puras.

Todas as relações entre nutrientes estudadas mostraram-se importantes na produção de sementes de grama-batatais (Tabelas de 27 a 36). Essas relações haviam sido selecionadas para consideração nes te estudo por terem afetado o desempenho de outras culturas (REEVE e SHIVE, 1944; WATANABE et alii, 1965; SARRUGE, 1968; EPSTEIN, 1975; FORNASIERI FILHO, 1982).

No caso presente, a relação $\mathrm{Ca} / \mathrm{Mg}$ das folhas correlacionou-se tanto com a qualidade como com a quantidade das sementes: dentro dos limites de variação verificados na primeira coleta $(1,00-2,21)$, quanto menor foi essa relação, melhor foi a qualidade das sementes; na segunda co leta, dentro dos limites de variação $(0,66$ - 1,50), quanto maior foi a relação, maior foi a produção de sementes. A variação da relação $\mathrm{Ca} / \mathrm{Mg}$ em função dos tratamentos aplicados é apresentada na Tabela 22 e comentada nos itens 4.1 e 4.5 .

As relações $\mathrm{K} / \mathrm{Mg}$ e $\mathrm{K} / \mathrm{Ca}+\mathrm{Mg}$ nas folhas afetaram tambēm a qualidade das sementes da primeira coleta, dentro de seus intervalos de variação de 3,15-12,48 e 1,48 - 5,24 respectivamente. A medida que os valores dessas relações diminuiram, melhorou a qualidade das sementes produzidas. A variação das relações $\mathrm{K} / \mathrm{Mg}$ e $\mathrm{K} / \mathrm{Ca}+\mathrm{Mg}$ em função dos tratamentos aplicados é apresentada na Tabela 22. A interação significativa entre fósforo e adubo orgânico na relação foliar K/Mg da primeira coleta já foi comentada no $i$ tem 4.5. A relação $\mathrm{K} / \mathrm{Ca}+\mathrm{Mg}$ variou em função das interações entre sulfato de amōnio e potássio, e entre fósforo e adubo orgānico: em ausência de adubação potássica, os valores diminuiram com aplicação de sulfá to de amōnio e, com adubação potássica, cresceram com aplicação de sulfato de amōnio; sem esterco, os valores cresceram com adubação fosfatada e, a plicando esterco, diminuiram com aplicação de fósforo. Na segunda coleta, os valores da relação K/Mg diminuiram com aplicação de adubo orgânico,mas, 
nessa coleta, não houve correlação entre os resultados e os valores dessa relação.

Houve também correlação significativa entre a qualidade das sementes e as relações $\mathrm{P} / \mathrm{Mg}$ e $\mathrm{Zn} / \mathrm{Fe}$ das folhas (negativa e positiva, respectivamente) dentro dos intervalos de variação na primeira coleta (Tabela 23).

As relações entre nutrientes nas sementes, dentro dos inter valos de variação verificados (Tabela 24), foram as mais freqüentemente li gadas à quantidade e à qualidade das sementes (Tabelas de 27 a 34 e Tabela 36). As maiores quantidades de sementes, na primeira coleta, foram correla cionadas positivamente com a relação $\mathrm{Ca} / \mathrm{Mg}$ e negativamente com $\mathrm{N} / \mathrm{K}, \mathrm{P} / \mathrm{Ca}$, $\mathrm{P} / \mathrm{Mg}, \mathrm{P} / \mathrm{S}, \mathrm{P} / \mathrm{Fe}, \mathrm{K} / \mathrm{Ca}$ e $\mathrm{Zn} / \mathrm{Mn}$. Na segunda coleta, as maiores quantidades de sementes correlacionaram se positivamente com as relações $\mathrm{Zn} / \mathrm{Cu}$ e $\mathrm{Zn} / \mathrm{Fe}$. Quanto à qualidade, na primeira coleta, as relações $\mathrm{K} / \mathrm{Mg}, \mathrm{P} / \mathrm{Mg}, \mathrm{Ca} / \mathrm{Mg}$, $\mathrm{P} / \mathrm{Zn}, \mathrm{Fe} / \mathrm{Mn}, \mathrm{N} / \mathrm{K}, \mathrm{P} / \mathrm{Ca}, \mathrm{K} / \mathrm{B}$ e $\mathrm{Ca} / \mathrm{B}$ foram correlacionadas positivamente com melhor qualidade das sementes; correlacionaram-se negativamente com qualidade as relaçõesN /P, P/S, Zn/Fe e $\mathrm{Zn} / \mathrm{Mn}$. Na segunda coleta, as produções de sementes de melhor qualidade correlacionaram-se positivamente com $\mathrm{Zn} / \mathrm{Mn}$, Fe/Mn, K/B eCa/B, apresentando correlação negativa com $\mathrm{Zn} / \mathrm{Fe}$.

$\mathrm{Na}$ segunda coleta, houve interferéncia da adubação potássica no efeito que o esterco e o sulfato de amônio exerceram na produção quantitativa de sementes (Tabelas 4, 5 e 22), como já foi comentado nos ítens $4.1,4.2$ e 4.3. Em ausenncia de adubação potássica, adição de esterco ou sulfato de amōnio favoreceu o aumento da produção de sementes, ocorrendo o contrário quando foi aplicado cloreto de potássio junto com os adubos nitrogenados.

$\mathrm{Na}$ produção quantitativa de sementes da segunda coleta, hou ve também influéncia da calagem no efeito dos adubos nitrogenados (Tabelas 5 e 6). Em auséncia de calagem, a adição de sulfato de amônio ou esterco provocou aumento na quantidade de sementes produzidas; com calagem, a adubação nitrogenada teve efeito contrário. 
0 aumento da produção de sementes de gramíneas forrageiras pela aplicação de nitrogēnio é fato freqüentemente relatado na literatura e, se ocorreu somente em auséncia de calagem, pode ter sido porque, com a calagem e conseqüente aumento da disponibilidade de cálcio no solo (Tabela 3), a adubação nitrogenada estimulou maior absorção de cálcio pelas plan tas. Os maiores teores de cálcio, tanto no solo como nas folhas, correspon deram às produções mais baixas de sementes da segunda coleta (Tabelas 27 , 28 e 32 ).

Em alguns trabalhos, verificou-se que, aumentando a aduba ção nitrogenada, ocorria um aumento na absorção de cálcio (WHITE et alii , 1965). Esse efeito sinergístico é atribuído à elevação da capacidade de troca catiōnica das raízes promovida pelo nitrogēnio, permitindo, assim, que as plantas absorvam mais cālcio (MASCARENHAS, 1977).

A concentração foliar de nitrogēnio, por sua vez, foi afe tada, na segunda coleta, pela interação entre adubações nitrogenada e po tássica: quando não se aplicou potāssio, as médias da concentração de ni trogênio na matēria seca de folhas variaram de $1,5 \%$ (sem aplicação de sulfa to de amōnio) para $1,7 \%$ (com aplicação de sulfato de amónio); quando foi aplicado potássio, as médias das concentrações de nitrogēnio variaram de $1,7 \%$ para $1,6 \%$ respectivamente sem e com aplicação de sulfato de amōnio . Verificou-se, portanto, mais uma vez, interferência da adubação potássica no efeito da adubação nitrogenada. Esse fato tem alguma semelhança com a constatação de EPPENDORFER e BILLE (1974) que, trabalhando com ervilha, verificaram um efeito negativo na absorção de nitrogēnio pela ervilha com adição de doses elevadas de potássio. O efeito da adubação potássica na elevação das concentrações foliares de nitrogênio em ausência de aplicação de sulfato de amônio, por outro lado, concorda com os dados obtidos por KOCH e MENGEL (1977), mostrando influência favorável do potássio na absorção de nitrogēnio por trigo.

De modo geral, não se evidenciou vantagem na aplicação de adubos e calcário dolomítico nesse solo de nível moderado de fertilidade. 
Esse fato tem sido constatado algumas vezes na produção de sementes de diversas plantas, inclusive gramineas (CICERO, 1979).

Houve efeito benéfico do fósforo, quando foi aplicado junta mente com potássio, mas isso somente se verificou nos resultados da primei ra coleta. A esse propósito, os dados da Tabela 3 mostram teores de fósforo elevados no solo na maioria das parcelas que receberam fósforo junto com potāssio. 
5. CONCLUSÕES

A. A nutrição mineral influencia a produção de sementes de grama-batatais em quantidade e qualidade.

B. Dentro do intervalo de variação de 0,90\%-1,57\% de carbo no no Latossol Vermelho Escuro, as porcentagens mais altas correspondem a maior quantidade e melhor qualidade das sementes produzidas.

C. Níveis de $0,25 \%$ de fósforo, $3,03 \%$ de potássio, $0,50 \%$ de cālcio, 0,40\% de magnésio, 280 ppm de ferro e $35 \mathrm{ppm}$ de zinco na matéria seca de folhas prejudicam a produção de sementes, em comparação com nī veis mais baixos.

D. Maior produção de sementes corresponde às menores con centrações de nitrogénio, boro e cobre (dentro dos intervalos de variação de $1,25 \%-1,52 \%, 19-44 \mathrm{ppm}$ e $5-17$ ppm respectivamente) e às mais elevadas de cálcio (dentro do intervalo de variação de 0,04\%-0,08\%) na matéria seca de sementes.

E. As sementes de melhor qualidade apresentam as concentra ções mais elevadas de cobre e zinco (dentro dos intervalos de variação de 7-17 ppm e 20-45 ppm respectivamente) e mais baixas de potássio e boro (dentro dos intervalos de variação de $0,23 \%-0,31 \%$ e 5-44 ppm respectiva mente).

$F$. As relações entre concentrações de nutrientes $N / P, N / K$, $\mathrm{N} / \mathrm{S}, \mathrm{P} / \mathrm{Ca}, \mathrm{P} / \mathrm{Mg}, \mathrm{P} / \mathrm{S}, \mathrm{P} / \mathrm{Fe}, \mathrm{P} / \mathrm{Zn}, \mathrm{K} / \mathrm{Ca}, \mathrm{K} / \mathrm{Mg}, \mathrm{K} / \mathrm{Ca}+\mathrm{Mg}, \mathrm{K} / \mathrm{B}, \mathrm{Ca} / \mathrm{Mg}, \mathrm{Ca} / \mathrm{B}$, $\mathrm{Fe} / \mathrm{Mn}, \mathrm{Zn} / \mathrm{Cu}, \mathrm{Zn} / \mathrm{Fe}$ e $\mathrm{Zn} / \mathrm{Mn}$ na matéria seca vegetal afetam a produção de sementes. 


\section{LITERATURA CITADA}

ALCÂNTARA, P.B. e G. BUFARAH. 1979. PZantas forrageiras: gramīneas e legu minosas. São Paulo, Nobel. 150 p.

ALENCAR, F.M.A. de. 1949. Plantas üteis para o revestimento do solo. Bragantia, Campinas, 9: 113-146.

ALOISI, R.R. e J.L.I. DEMATTE. 1974. Levantamento dos solos da Faculdade de Medicina Veterināria e Agronomia de Jaboticabal. Cientifica, Jaboti cabal, 2(2): 123-136.

ARONOVICH, S., D.P.P.S. BRITTO e C.A. MENEGUELLI. 1973. Influēncia da adu bação sobre a composição botãnica e sobre a produção de pastagens. Pes quisa Agropecuária Brasileira, Série Zootecnia, Brasîlia, 8(2): 19-26.

AUSTIN, R.B. 1972. Effects of environment before harvesting on viability. In ROBERTS, E.H., Ed. Viability of seeds. London, Chapman and Hall. p. 114-149.

BURTON, G.W. 1943. Factors influencing seed setting in several southern grasses. Jourmal of the American Society of Agronomy, Geneva, 35: 465-474.

BURTON, G.W. 1944. Seed production of several southern grasses as influen ced by burning and fertilization. Joumal of the American Society of Agronomy, Geneva, 36: 523-529. 
CARVALHO, N.M. de e J. NAKAgAWA. 1980. Sementes; ciēncia, tecnologia e produção. Campinas, Cargill. 326 p.

CHAUDHRY, F.M. e M. SHARIF. 1974. Micronutrient problems of crops in Pakistan with special reference to zinc and copper deficiency in rice production. In FAO. Isotope-aided micronutrient studies in rice produc tion with special reference to zine deficiency. Vienna, FAO/IAEA. p. $1-24$.

CICERO, S.M. 1979. Efeitos da fertilidade do solo sobre a produção e a qualidade das sementes de milho (Zea mays L.). Piracicaba, E. S.A. "Luiz de Queiroz" da USP. 85 p. (Tese de Doutorado).

COMISSAO DE SOLOS. 1960. Levantamento de reconhecimento dos solos do Esta do de São Paulo. Rio de Janeiro, Ministério da Agricultura. 634 p. (Boletim no 12).

CORREAA, M.P. 1926. Diccionario das plantas üteis do Brasil e das exóticas cultivadas. v. III. Rio de Janeiro, Imprensa Nacional. p. 460-461.

COUTINHO, E.L.M., G.C. VITTI, N.O. ALEJO, N.J. NOVAES e V.L. FURLANI NE T0. 1979. Interação entre nutrientes: absorção, transporte e metabolis mo. Piracicaba, E.S.A. "Luiz de Queiroz" da USP. 63 p. (Trabalho apresentado à disciplina de Nutrição Mineral de Plantas do Curso de Pōs -graduação em Solos e Nutrição de Plantas).

DEMATTÉ, M.E.S.P., E.B. MALHEIROS, G.C. VITTI e H.P. HAAG. 1983 a. Correlações entre características de produção de folhas, inflorescéncias e sementes de grama-batatais (Paspalum notatum Flügge). Resumos dos Trabalhos Técnicos, III Congresso Brasileiro de Sementes, 1983, Campinas: 101.

DEMATTÊ, M.E.S.P., R. SADER e J.R. de MENDONÇA. 1983 b. Testes de quebra de dorméncia em sementes de grama-batatais (Paspalum notatum Flügge). Resumos dos Trabalhos Técnicos, III Congresso Brasileiro de Sementes, 1983, Campinas: 20.

DÖBEREINER, J. e R.M. BODDEY. 1981. Nitrogen fixation in association with Gramineae. In GIBSON, A.H. e W.E. NEWTON, Ed. Current perspectives in 
nitrogen fixation. Canberra, Australian Academy of Science; Amsterdam, El sevier; Rio de Janeiro, Conselho Nacional de Pesquisas. p. 305-312.

EPPENDORFER, W.H. e S.W. BILLE. 1974. Aminoacid composition as a fuction of total $\mathrm{N}$ in pea seeds grown on two soils with $\mathrm{P}$ and $\mathrm{K}$ additions. Plant and Soir, The Hague, 41: 33-39.

EPSTEIN, E. 1975. Nutriøão mineral de plantas; princípios e perspectivas. Trad. e notas de E. Malavolta. Rio de Janeiro, Editora da Universidade de São Paulo - Livros Técnicos e Científicos. 341 p.

FAVORETTO, V. 1982. Maturação e colheita de sementes de gramîneas e leguminosas forrageiras. In INSTITUTO DE Z0OTECNIA. Curso de produção $e$ tecnologia de sementes de forrageiras. Nova Odessa, Secretaria Nacio nal de Produção Agropecuāria, Instituto de Zootecnia. 1 v.

FORNASIERI FILHO, D. 1982. Efeitos do N, P, K, S e Zn no desenvolvimento, produção e composição mineral do arroz (Oriza sativa L.), cv. IAC 47 e IAC 435. Piracicaba, E.S.A. "Luiz de Queiroz" da USP. 157 p. (Tese de Doutorado).

GROHMANN, F., J.B. de OLIVEIRA e J.P. de QUEIROZ NETO. 1966. Influência da adubação nas características dos agregados do solo da série "Chapadão" (Latossolo Roxo). Bragantia, Campinas, 25: 263-275.

GRUNES, D.L., P.R. SOUT E J.R. BROWNELL. 1970. Grass tetany of ruminants. Advances in Agronomy, New York, 22: 331-374.

HADAS, A. e J. HAGIN . 1972. Boron adsorption by soils as influenced by potassium. Soil Science, Baltimore, 113(3): 189-193.

HODGES, E.M. e F.G. MARTIN. 1975. Forage production of perennial grasses as affected by fertilizer rate and season. Proceedings, Soil and Scien ce Society of Florida, Belle Glade, 34: 158-161.

JONES, R.J. e R. ROE. 1976. Seed production, harvesting and storage. In SHAW, N.H. e W.W. BRYAN, Ed. Tropical pasture research; principles and methods. Farnham Royal, Commonwealth Agricultural Bureaux. p. 378-442. 
JORGENSEN, S.S. 1977. Metodologia utilizada para análises quimicas de rotina; guia analitico. Piracicaba, Centro de Energia Nuclear na Agricul tura. $24 \mathrm{p}$.

KOCH, K. e K. MENGEL. 1977. Effect of $\mathrm{K}$ on $\mathrm{N}$ utilization by spring wheat during grain protein formation. Agronomy Joumal, Washington, 69 : 477-480.

LAL, R., G.F. WILSON e B.N. OKIGBO. 1979. Changes in properties of an alfisol produced by various crop covers. Soil Science, Baltimore, 127 (6): $377-382$.

LAMBERT, D.A. 1965. The effects of irrigation and level of nitrogen on the seed production of $\$ 48$ timothy. Exps. Progrs. 17 Grassld. Res . Inst. 1963-64: 41. Apud Herbage Abstracts, Farham Royal, 35 (4): 260 , 1965. [ ref. 1845 ].

LAMPETER, W. et alii. 1965. [ Effect of seed rate and $\mathrm{N}$ application on yields of grass seed.] Quedliburg, VVB. Saat -und Pflanzgut. 142 p. Apud Herbage Abstracts, Farham Royal, 36 (4): 279, 1966, [ ref. 2088].

LAWRENCE, R.M., Jr. 1975. The influence of nitrogen and maleic hydrazide (MH-30) on the growth and chemical composition of Wilmington Bahia grass (Paspalum notatum Flügge). Dissertation Abstracts International B, Ann Arbor, 35 (8): 3711-3712.

MAGUIRE, J.D. 1962. Speed of germination - aid in selection and evalua tion for seedling emergence and vigor. Crop Science, Madison, 2 (2) : 176-177.

MALAVOLTA, E. e 0. LOPEZ GOROSTIAGA. 1974. Studies on the zinc phosphate relationships in plant. Proc. VII International Colloquium on Plant Analysis and Fertilizer Problems, Hannover. p. 261-272.

MASCARENHAS, H.A.A. 1977. Cálcio, enxofre e ferro no solo e na planta. Campinas, Cargill. 95 p. 
MILLER, G.W., J.C. BROWN e R.S. HOLMES. 1959. Chlorosis in soybean as related to iron, phosphorus, bicarbonate and cytochrome oxidade activi ty. Plant Physiology, Lancaster, 35: 619-625.

NEYRA, C.A. e J. DOBEREINER. 1977. Nitrogen fixation in grasses. Advances in Agronomy, New York, 29: 1-38.

OTERO, J.R. de. 1961. Informąões sobre algumas plantas forrageiras. Rio de Janeiro, Ministērio da Agricultura. 331 p.

POLLOCK, J.E. 1956. Experience with row crops following perennial gras ses. Better Crops With Plant Food, New York, 40 (9): 6-10.

PRATES, E.R. 1977. Efeito de doses de nitrogénio e de intervalos entre cortes sobre a produção e composição de dois ecotipos de Paspazum nota tron Flügge e da cultivar Pensacola Paspazzon notation Flügge var. saurae Parodi. Anuário Técnico do Instituto de Pesquisas Zootécnicas "Francis co Osómio", Porto Alegre, 4: 267-307.

QUELLETTE, G.J. 1963. The potassium-boron relation in the cultivation of lucerne. Canadian Journal of Soiz Science, Ottawa, 43: 59-64.

RAIJ, B. van e M.A.T. ZULLO. 1977. Métodos de anäZises de solo. Campi nas, Instituto Agronōmico. 16 p. (Circular nọ 63).

REEVE, E. e J.W. SHIVE. 1944. Potassium-boron and calcium-boron relation ships in plant nutrition. Soil Science, New Brunswick, 57: 1-14.

RICHARDSON, E. e E.G. DISEKER. 1965. Establishing and maintaining roadsi de cover in the Piedmont Plateau of Georgia. Agronomy Joumal, Washington, 57: 561-564.

ROCHA, G.L. da. 1958. A grama de batatais. Revista dos Criadores, São Paulo, 29 (339): 26-27.

SARRUGE, J.R. 1968. Estudos sobre as relações cālcio/boro e potāssio/boro no cafeeiro. Piracicaba, E.S.A. "Luiz de Queiroz" da USP. 78 p. (Tese de Doutoramento). 
SARRUGE, J.R. e H.P. HAAG. 1974. Análises químicas em plantas. Piracica ba, E.S.A. "Luiz de Queiroz" da USP. 57 p.

SOUZA, H.M. de. 1968. Formação e conservação de gramados. O Agronômico, Campinas, 20 ( 3 e 4$): 17-33$.

TOLEDO, F.F. de; J.MARCOS FILHO, M.B. SILVAROLLA e J.F. BATISTA NETO • 1981. Maturação e dorméncia de sementes de grama batatais. Revista de Agricultura, Piracicaba, 56 ( 1 e 2): 83-91.

TORRES, A. Di P. 1954. Agressividade de algumas gramineas forrageiras na região de Piracicaba. Anais da E.S.A. "Luiz de Queiroz", Piracicaba, 11: $93-114$.

TURKIEWICZ, L. 1976. Efeito da calagem e adubação fosfatada sobre a germi nação e o vigor de sementes de soja (Glycine max (L.) Merril). Piracicaba, E.S.A. "Luiz de Queiroz". 85 p. (Dissertação de Mestrado).

VIETS, F.G., A.L. MOXON e E.I. WHITEHEAD. 1964. Nitrogen metabolism of corn as influenced by ammonia nutrition. Plant Physiology, Lancaster, 21: $271-298$.

VITTI, G.C. e A.A. RODELLA. 1982. A determinação do enxofre em material vegetal pelo método turbidimétrico. Jaboticabal, FCAVJ-UNESP. 5 p.

WATANABE, F.S., W.L. LINDSAY e S.R. OLSEN. 1965. Nutrient balance invol ving phosphorus, iron and zinc. Proceedings of the Soil Science Society of America, Ann Arbor, 29: 562-565.

WEIER, K.L. 1980. Nitrogen fixation associated with grasses. Tropical Grasszands, Brisbane, 14 (3): 194-201.

WHEELER, W.A. e D.D. HILL. 1957. Grassiand seeds. Princeton, D. van Nos trand. $734 \mathrm{p}$.

WHITE, R.P., M. DRAKE e J.H. BAKER. 1965. Effect of induced changes in root CEC on Ca absorption from bentonite systems by excised barley roots. Soiz Science, New Brunswick, 99: 267-270. 
WILCOX, G.E., J.E. HOFF e C. JONES. 1973. Ammonium reduction of calcium and magnesium content of tomato and sweet corn leaf tissue and in fluence on incidence of blossom and rot of tomato fruit. Jowmal of the American Society for Horticultural Science, Saint Joseph, 98 (1) : 86-89. 
APENDICE 
Tabela 1. Dados climāticos registrados na FCAVJ-UNESP, em Jaboticabal, SP, no periodo de agosto de 1981 a abril de 1982.

\begin{tabular}{|c|c|c|c|c|c|c|c|}
\hline \multirow[b]{3}{*}{ Ano } & \multirow[b]{3}{*}{ Mès } & \multicolumn{3}{|c|}{ Temperaturas $\left({ }^{\circ} \mathrm{C}\right)$} & \multirow{3}{*}{$\begin{array}{l}\text { Umidade } \\
\text { relativa } \\
\text { do ar } \\
(\%)\end{array}$} & \multirow{3}{*}{$\begin{array}{l}\text { Precipi- } \\
\text { tação } \\
\text { total } \\
(\mathrm{mm})\end{array}$} & \multirow{3}{*}{$\begin{array}{c}\text { Insolação } \\
\text { total } \\
\text { (h) }\end{array}$} \\
\hline & & māxima & mīnima & média & & & \\
\hline & & & & & & & \\
\hline \multirow[t]{5}{*}{1981} & agos to & 33,8 & 9,4 & 20,9 & 52,9 & 3,3 & 230,0 \\
\hline & se tembro & 35,6 & 10,2 & 23,2 & 50,3 & 29,9 & 212,0 \\
\hline & outubro & 33,0 & 11,2 & 22,1 & 73,8 & 263,9 & 196,6 \\
\hline & novembro & 33,3 & 17,3 & 24,2 & 75,6 & 97,2 & 222,7 \\
\hline & dezembro & 31,1 & 15,8 & 23,2 & 79,9 & 220,7 & 246,1 \\
\hline \multirow[t]{4}{*}{1982} & janeiro & 32,3 & 15,6 & 22,9 & 81,8 & 364,7 & 158,0 \\
\hline & fevereiro & 33,3 & 17,9 & 24,4 & 74,3 & 212,0 & 201,7 \\
\hline & março & 31,3 & 17,2 & 22,8 & 86,1 & 337,1 & 140,3 \\
\hline & abril & 31,4 & 12,5 & 21,0 & 73,8 & 44,1 & 239,8 \\
\hline
\end{tabular}


Tabela 2. Tratamentos para produção de sementes de grama-batatais.

\begin{tabular}{|c|c|c|c|c|c|}
\hline \multirow[b]{2}{*}{ Tratamentos ${ }^{\mathrm{a} /}$} & \multicolumn{5}{|c|}{ Doses aplicadas por parcela $\left(1 \mathrm{~m}^{2}\right)$} \\
\hline & $\begin{array}{r}N \\
(g) \\
\end{array}$ & $\begin{array}{l}\mathrm{P}_{2} \mathrm{O}_{5} \\
(\mathrm{~g}) \\
\end{array}$ & $\begin{array}{l}\mathrm{K}_{2} \mathrm{O} \\
(\mathrm{g}) \\
\end{array}$ & $\begin{array}{l}\begin{array}{c}\text { Calcārio } \\
\text { dolomítico } \\
(\mathrm{g})\end{array} \\
\end{array}$ & $\begin{array}{l}\text { Esterco de } \\
\text { equino } \\
\text { (1itros) }\end{array}$ \\
\hline Tes temunha & 0 & 0 & 0 & 0 & 0 \\
\hline $\mathrm{N}$ & 4 & 0 & 0 & 0 & 0 \\
\hline $\mathrm{p}$ & 0 & 50 & 0 & 0 & 0 \\
\hline K & 0 & 0 & 15 & 0 & 0 \\
\hline cal. & 0 & 0 & 0 & 200 & 0 \\
\hline A. 0 . & 0 & 0 & 0 & 0 & 10 \\
\hline$N P$ & 4 & 50 & 0 & 0 & 0 \\
\hline NK & 4 & 0 & 15 & 0 & 0 \\
\hline $\mathrm{N}$ cal. & 4 & 0 & 0 & 200 & 0 \\
\hline$N$ A. 0 . & 4 & 0 & 0 & 0 & 10 \\
\hline PK & 0 & 50 & 15 & 0 & 0 \\
\hline P cal. & 0 & 50 & 0 & 200 & 0 \\
\hline P A. 0 . & 0 & 50 & 0 & 0 & 10 \\
\hline $\mathrm{K}$ cal. & 0 & 0 & 15 & 200 & 0 \\
\hline K A. 0 . & 0 & 0 & 15 & 0 & 10 \\
\hline cal. A. 0 . & 0 & 0 & 0 & 200 & 10 \\
\hline NPK & 4 & 50 & 15 & 0 & 0 \\
\hline NP cal. & 4 & 50 & 0 & 200 & 0 \\
\hline NP A.0. & 4 & 50 & 0 & 0 & 10 \\
\hline NK cal. & 4 & 0 & 15 & 200 & 0 \\
\hline NK A.0. & 4 & 0 & 15 & 0 & 10 \\
\hline $\mathrm{N}$ cal. A. 0 . & 4 & 0 & 0 & 200 & 10 \\
\hline PK cal. & 0 & 50 & 15 & 200 & 0 \\
\hline PK A.0. & 0 & 50 & 15 & 0 & 10 \\
\hline P cal. A.0. & 0 & 50 & 0 & 200 & 10 \\
\hline K cal. A. 0 . & 0 & 0 & 15 & 200 & 10 \\
\hline NPK cal. & 4 & 50 & 15 & 200 & 0 \\
\hline NPK A.0. & 4 & 50 & 15 & 0 & 10 \\
\hline NP cal. A.0. & 4 & 50 & 0 & 200 & 10 \\
\hline NK cal. A.0. & 4 & 0 & 15 & 200 & 10 \\
\hline PK cal. A.0. & 0 & 50 & 15 & 200 & 10 \\
\hline NPK cal. A.0. & 4 & 50 & 15 & 200 & 10 \\
\hline
\end{tabular}

a/ $N=$ nitrogênio; $P=$ fösforo; $K=$ potāssio; cal. = calcário dolomítico; $A_{0}$. . = adubo orgānico (esterco de equino). 
Tabela 3. Resultados analíticos de amostras de solo coletadas posteriormente a adubação e calagem.

\begin{tabular}{|c|c|c|c|c|c|c|c|c|}
\hline \multirow[t]{2}{*}{ Tratamentos ${ }^{a /}$} & \multirow[t]{2}{*}{$\% C$} & \multirow[t]{2}{*}{$\mathrm{pH}$ em $\mathrm{H}_{2} \mathrm{O}$} & \multicolumn{2}{|c|}{$\begin{array}{c}\text { Teores em ug/mi } \\
\text { T.F.S.A. }\end{array}$} & \multicolumn{3}{|c|}{$\begin{array}{c}\text { Teores em c.mig/100 } \mathrm{ml} \\
\text { T.F.S.A. }\end{array}$} & \multirow[t]{2}{*}{$\mathrm{H}^{+}$} \\
\hline & & & $P$ & $k$ & $\mathrm{Al}^{+++}$ & $\mathrm{Ca}^{++}$ & $\mathrm{Mg}^{++}$ & \\
\hline Tes temunha & 0,90 & 5,7 & 8 & 291 & 0 & 4,8 & 1,4 & 3,6 \\
\hline$N$ & 1,52 & 5,8 & 7 & 221 & 0 & 1,6 & 0,7 & 4,9 \\
\hline$p$ & 1,39 & 6,4 & 8 & 228 & 0 & 4,9 & 1,5 & 3,8 \\
\hline$k$ & 1,53 & 5,8 & 7 & 306 & 0 & 1,7 & 0,7 & 3,4 \\
\hline cal. & 1,51 & 6,4 & 13 & 236 & 0 & 5,2 & 2,1 & 2,7 \\
\hline A.0. & 1,48 & 6,7 & 22 & 299 & 0 & 4,9 & 2,1 & 3,6 \\
\hline NP & 1,56 & 6,2 & 95 & 228 & 0 & 1,2 & 0,7 & 4,2 \\
\hline NK & 1,32 & 5,9 & 8 & 306 & 0 & 1,0 & 0,7 & 3,0 \\
\hline $\mathrm{N}$ cal. & 1,50 & 6,3 & 8 & 236 & 0 & 4,8 & 1,4 & 2,6 \\
\hline N A.O. & 1,53 & 5,7 & 16 & 252 & 0 & 1,2 & 0,5 & 4,5 \\
\hline PK & 1,28 & 6,4 & 122 & 228 & 0 & 1,5 & 0,8 & 3,8 \\
\hline P cal. & 1,38 & 6,5 & 78 & 236 & 0 & 5,3 & 2,5 & 3,0 \\
\hline P A.0. & 1,24 & 6,6 & 89 & 228 & 0 & 5,1 & 2,2 & 3,6 \\
\hline K cal. & 1,31 & 5,8 & 9 & 314 & 0 & 1,0 & 0,5 & 3,2 \\
\hline K A.0. & 1,38 & 6,2 & 75 & 345 & 0 & 4,9 & 1,4 & 3,4 \\
\hline cal. A.0. & 1,27 & 6,1 & 24 & 299 & 0 & 1,5 & 0,8 & 2,9 \\
\hline NPK & 1,41 & 6,1 & 118 & 275 & 0 & $2,-1$ & 0,7 & 5,2 \\
\hline NP cal. & 1,53 & 5,8 & 80 & 228 & 0 & 2,2 & 0,5 & 3,8 \\
\hline NP A. 0. & 1,36 & 6,3 & 118 & 213 & 0 & 1,5 & 0,4 & 4,9 \\
\hline NK cal. & 0,91 & 6,3 & 8 & 275 & 0 & 5,2 & 1,9 & 2,9 \\
\hline NK A.0. & 1,51 & 6,2 & 11 & 338 & 0 & 1,3 & 0,8 & 4,0 \\
\hline$N$ cal. A.0. & 1,26 & 5,5 & 116 & 275 & 0 & 1,1 & 0,2 & 2,8 \\
\hline PK cal. & 1,26 & 6,1 & 8 & 267 & 0 & 5,0 & 1,9 & 3,3 \\
\hline PKA.0. & 1,29 & 6,1 & 14 & 283 & 0 & 5,1 & 2,7 & 3,5 \\
\hline$P$ cal. A.0. & 1,56 & 6,4 & 97 & 272 & 0 & 5,3 & 3,5 & 3,2 \\
\hline K cal. A. 0 . & 1,53 & 5,7 & 17 & 353 & 0 & 2,2 & 0,6 & 2,6 \\
\hline NPK cal. & 1,57 & 6,5 & 105 & 228 & 0 & 5,1 & 2,1 & 3,4 \\
\hline NPK A.0. & 1,33 & 6,4 & 107 & 252 & 0 & 5,1 & 2,1 & 4,3 \\
\hline NP cal. A.0. & 1,41 & 5,8 & 129 & 236 & 0 & 1,5 & 0,8 & 3,8 \\
\hline NK cal. A.O. & 1,50 & 6,1 & 20 & 322 & 0 & 4,9 & 1,8 & 3,4 \\
\hline PK cal. A.0. & 1,40 & 6,0 & 87 & 291 & 0 & 2,2 & 0,8 & 3,4 \\
\hline NPK cal. A.0. & 1,20 & 5,8 & 74 & 267 & 0 & 5,3 & 2,7 & 2,6 \\
\hline
\end{tabular}

a/ $N=$ nitrogênio; $P=$ fósforo; $K=$ potāssio; cal. = cal cário dolomítico; A.0. = adubo orgānico (esterco de equino). 
Tabela 4. Mëdias do nūmero de espigas por parcela $\left(0,25 \mathrm{~m}^{2}\right)$ de grama-batatais em duas coletas (dezembro de 1981 e abril de 1982).

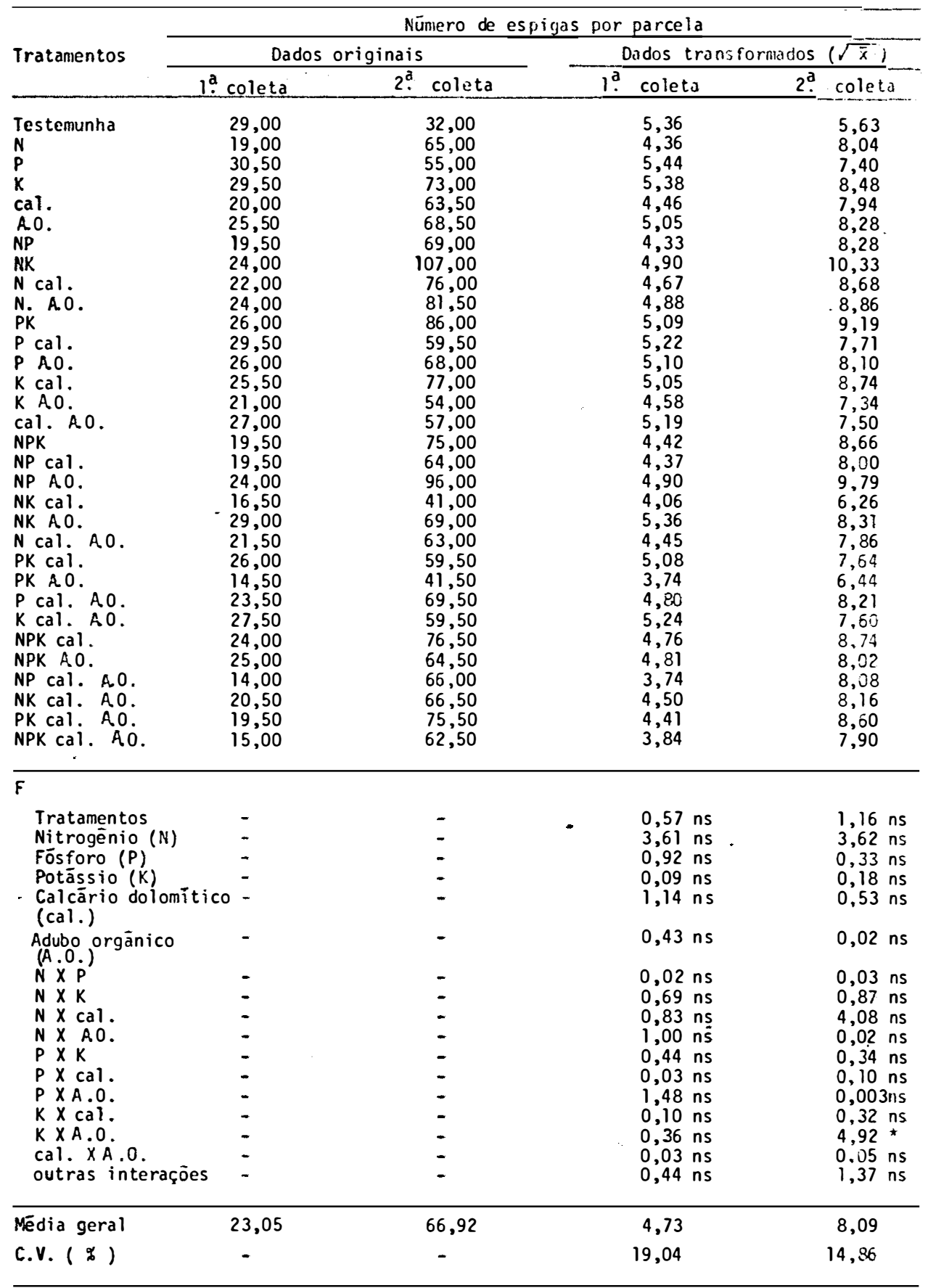

Observações: $n s=$ não significativo a $5 \%$ de probabilidade; * = significativo a $5 \%$ de probabilidade. 
Tabe la 5. Mëdias das produções em peso de sementes por parcela $\left(0,25 \mathrm{~m}^{2}\right)$ de grama-batatais em duas coletas (dezembro de 1981 e abril de 1982).

\begin{tabular}{|c|c|c|c|c|c|c|c|}
\hline \multirow{3}{*}{ Tratamentos } & \multicolumn{7}{|c|}{ Peso de sementes por parcela (3) } \\
\hline & \multicolumn{4}{|c|}{ Total } & \multicolumn{3}{|c|}{ Sementes puras } \\
\hline & $1 !$ & coleta & 2 ? & coleta & $1^{a}$ & coleta & 2. coleta \\
\hline 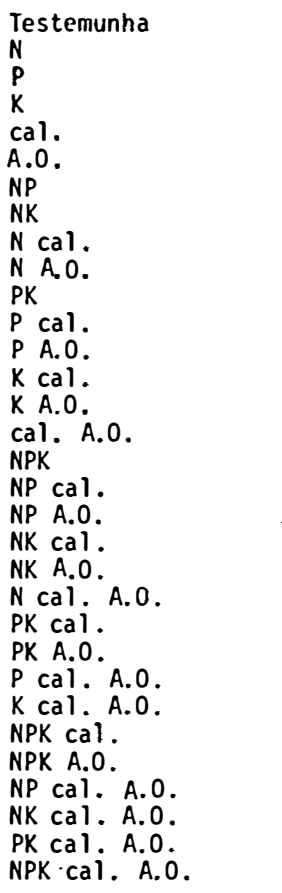 & - & $\begin{array}{l}4,18 \\
2,22 \\
3,44 \\
2,22 \\
2,34 \\
2,78 \\
1,93 \\
3,42 \\
2,88 \\
2,76 \\
3,30 \\
2,20 \\
2,51 \\
2,44 \\
2,99 \\
4,41 \\
3,04 \\
1,27 \\
3,22 \\
1,83 \\
3,16 \\
4,04 \\
3,27 \\
1,50 \\
2,83 \\
2,58 \\
2,82 \\
4,29 \\
2,52 \\
1,92 \\
2,73 \\
2,23\end{array}$ & & $\begin{array}{r}4,23 \\
7,03 \\
7,64 \\
8,05 \\
8,54 \\
8,61 \\
8,30 \\
12,80 \\
7,83 \\
10,91 \\
10,23 \\
8,14 \\
7,50 \\
6,82 \\
6,36 \\
6,82 \\
8,31 \\
7,98 \\
13,70 \\
3,80 \\
9,18 \\
6,15 \\
7,73 \\
5,98 \\
9,10 \\
7,96 \\
9,17 \\
6,94 \\
7,66 \\
6,74 \\
8,66 \\
7,07\end{array}$ & & $\begin{array}{l}0,50 \\
0,14 \\
0,46 \\
0,51 \\
0,37 \\
0,24 \\
0,04 \\
0,09 \\
0,31 \\
0,44 \\
0,30 \\
0,17 \\
0,40 \\
0,51 \\
0,22 \\
0,30 \\
0,18 \\
0,28 \\
0,53 \\
0,20 \\
0,43 \\
0,17 \\
0,41 \\
0,16 \\
0,27 \\
0,21 \\
0,43 \\
0,42 \\
0,07 \\
0,41 \\
0,15 \\
0,26\end{array}$ & $\begin{array}{r}2,26 \\
4,17 \\
5,18 \\
5,40 \\
6,05 \\
6,28 \\
5,30 \\
10,20 \\
5,46 \\
8,14 \\
7,91 \\
5,69 \\
5,04 \\
3,76 \\
3,49 \\
3,65 \\
5,22 \\
4,99 \\
11,04 \\
1,87 \\
6,17 \\
3,82 \\
5,13 \\
3,46 \\
6,18 \\
4,97 \\
6,14 \\
4,30 \\
5,49 \\
4,10 \\
6,00 \\
4,29\end{array}$ \\
\hline \multicolumn{8}{|l|}{$\bar{F}$} \\
\hline $\begin{array}{l}\text { Tratamentos } \\
\text { Nitrogēnio }(N) \\
\text { Fósforo }(P) \\
\text { Potāssio }(K) \\
\text { Calcărio dolomiti } \\
\text { (cal.) }\end{array}$ & ico & $\begin{array}{l}1,22 \mathrm{~ns} \\
0,30 \mathrm{~ns} \\
0,60 \mathrm{~ns} \\
0,20 \mathrm{~ns} \\
1,34 \mathrm{~ns}\end{array}$ & & $\begin{array}{l}1,36 \mathrm{~ns} \\
1,33 \mathrm{~ns} \\
1,60 \mathrm{~ns} \\
0,20 \mathrm{~ns} \\
2,58 \mathrm{~ns}\end{array}$ & & $\begin{array}{l}0,83 \mathrm{~ns} \\
0,74 \mathrm{~ns} \\
0,35 \mathrm{~ns} \\
0,06 \mathrm{~ns} \\
0,36 \mathrm{~ns}\end{array}$ & $\begin{array}{l}1,36 \mathrm{~ns} \\
1,20 \mathrm{~ns} \\
1,53 \mathrm{~ns} \\
0,45 \mathrm{~ns} \\
2,89 \mathrm{~ns}\end{array}$ \\
\hline 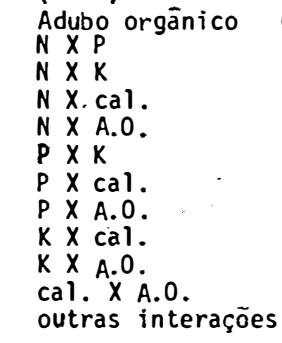 & $\begin{array}{l}\text { (A.0 } \\
\text { s }\end{array}$ & $\begin{array}{l}0,85 \mathrm{~ns} \\
0,10 \mathrm{~ns} \\
1,96 \mathrm{~ns} \\
1,24 \mathrm{~ns} \\
2,14 \mathrm{~ns} \\
4,43 \star \\
0,28 \mathrm{~ns} \\
0,41 \mathrm{~ns} \\
0,81 \mathrm{~ns} \\
1,98 \mathrm{~ns} \\
1,44 \mathrm{~ns} \\
1,31 \mathrm{~ns}\end{array}$ & & $\begin{array}{l}0,08 \mathrm{~ns} \\
0,09 \mathrm{~ns} \\
0,49 \mathrm{~ns} \\
7,13 \star \\
0,13 \mathrm{~ns} \\
0,60 \mathrm{~ns} \\
0,94 \mathrm{~ns} \\
0,22 \mathrm{~ns} \\
0,18 \mathrm{~ns} \\
3,74 \mathrm{~ns} \\
0,06 \mathrm{~ns} \\
1,52 \mathrm{~ns}\end{array}$ & & $\begin{array}{l}0,05 \mathrm{~ns} \\
0,44 \mathrm{~ns} \\
0,62 \mathrm{~ns} \\
0,10 \mathrm{~ns} \\
7,09 \star \\
0,001 \mathrm{~ns} \\
0,19 \mathrm{~ns} \\
0,05 \mathrm{~ns} \\
1,51 \mathrm{~ns} \\
0,35 \mathrm{~ns} \\
2,74 \mathrm{~ns} \\
0,75 \mathrm{~ns}\end{array}$ & $\begin{array}{l}0,03 \text { ns } \\
0,39 \text { ns } \\
0,40 \text { ns } \\
4,91 \text { * } \\
0,45 \text { ns } \\
0,49 \text { ns } \\
0,90 \text { ns } \\
0,02 \text { ns } \\
0,16 \text { ns } \\
4,29 \star \\
0,09 \text { ns } \\
1,60 \text { ns }\end{array}$ \\
\hline $\begin{array}{l}\text { Media geral } \\
\text { C.V. }(\%)\end{array}$ & & $\begin{array}{r}2,79 \\
35,27\end{array}$ & & $\begin{array}{r}8,00 \\
30,36\end{array}$ & & $\begin{array}{r}0,30 \\
72,80\end{array}$ & $\begin{array}{r}5,35 \\
43,82\end{array}$ \\
\hline
\end{tabular}

Observações: ns = não significativo a $5 \%$ de probabilidade; * = significativo a $5 \%$ de probabilidade. 
Tabela 6. Médias das relações entre peso de sementes puras e peso total de sementes por parcela e médias do peso de 1000 sementes puras nas diferentes parcelas de grama-batatais em duas coletas (dezembro de 1981 e abril de 1982).

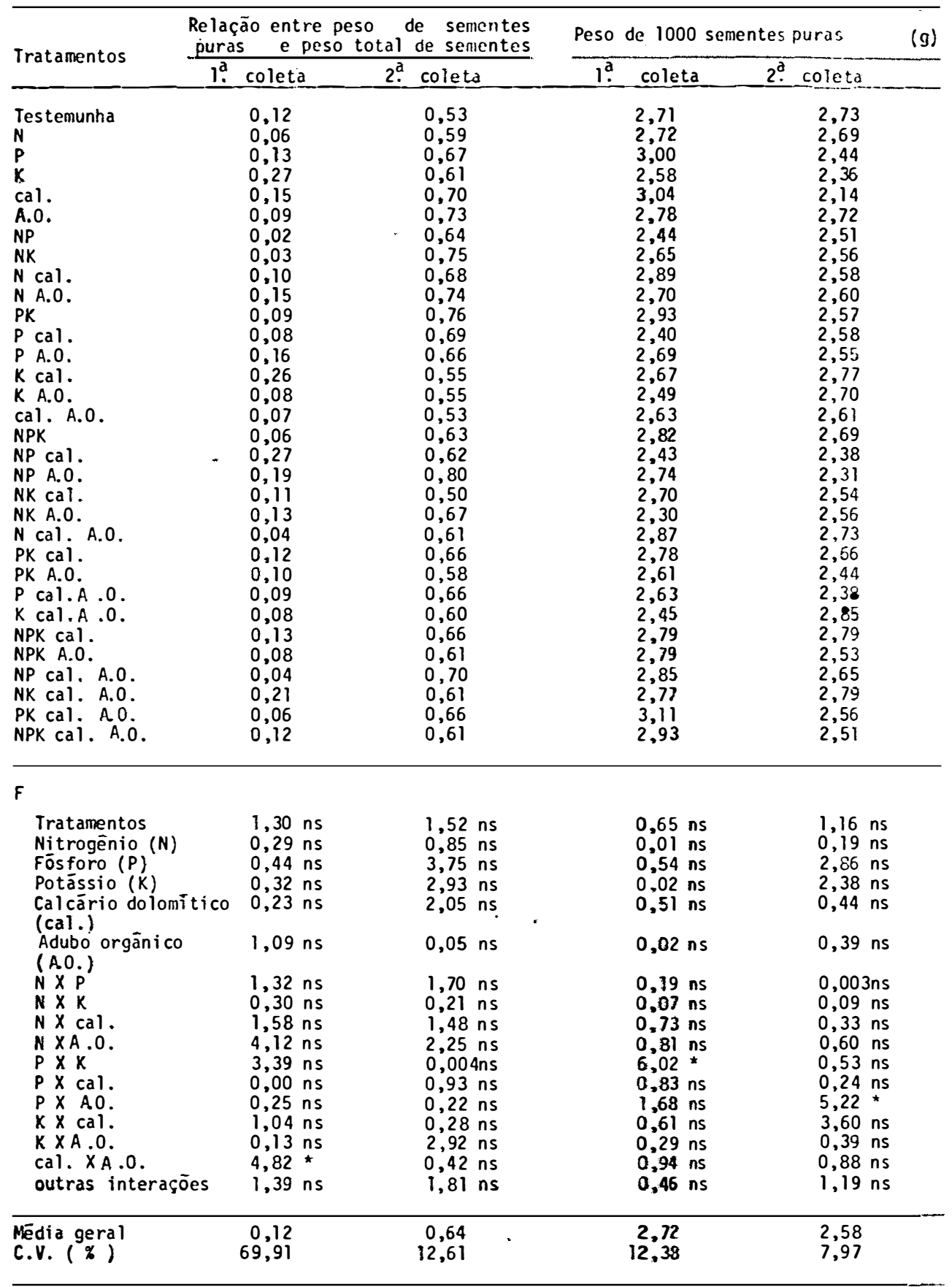

Observações: $n s=$ não significativo a $5 \%$ de probabilidade; * = significativo a $5 \%$ de probabilidade. 
Tabela 7. Médias de peso total de sementes por espiga e pe so de sementes puras por espiga nas diferentes parcelas de grama-batatais em duas coletas (de zembro de 1981 e abril de 1982).

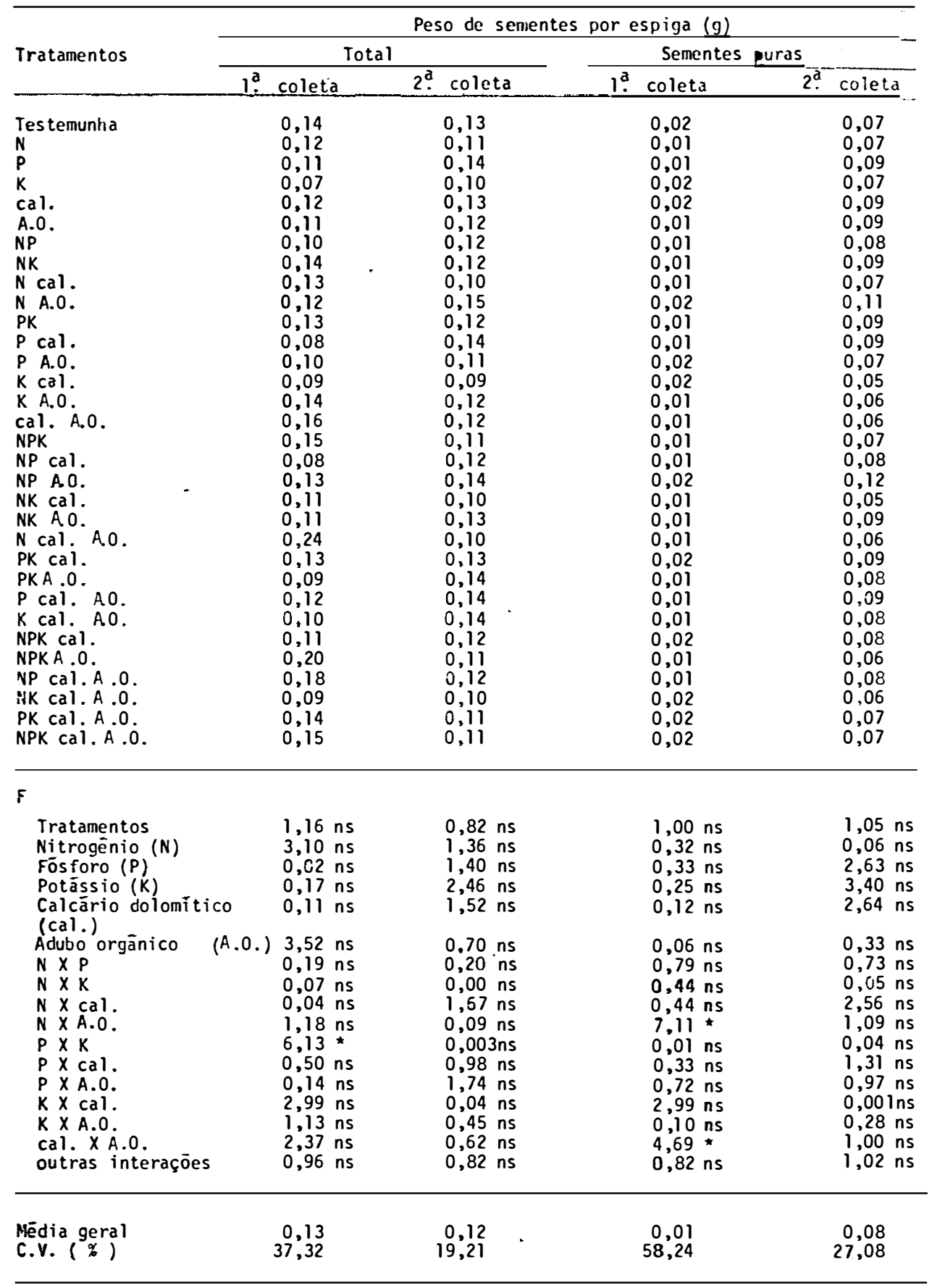

Observações: $n s=$ não significativo a $5 \%$ de probabilidade; * = significativo a $5 \%$ de probabilidade. 
Tabela 8. Médias de porcentagens de germinação de sementes não tratadas, em substrato umedecido com àgua , nas diferentes parcelas de grama-batatais em duas coletas (dezembro de 1981 e abril de 1982).

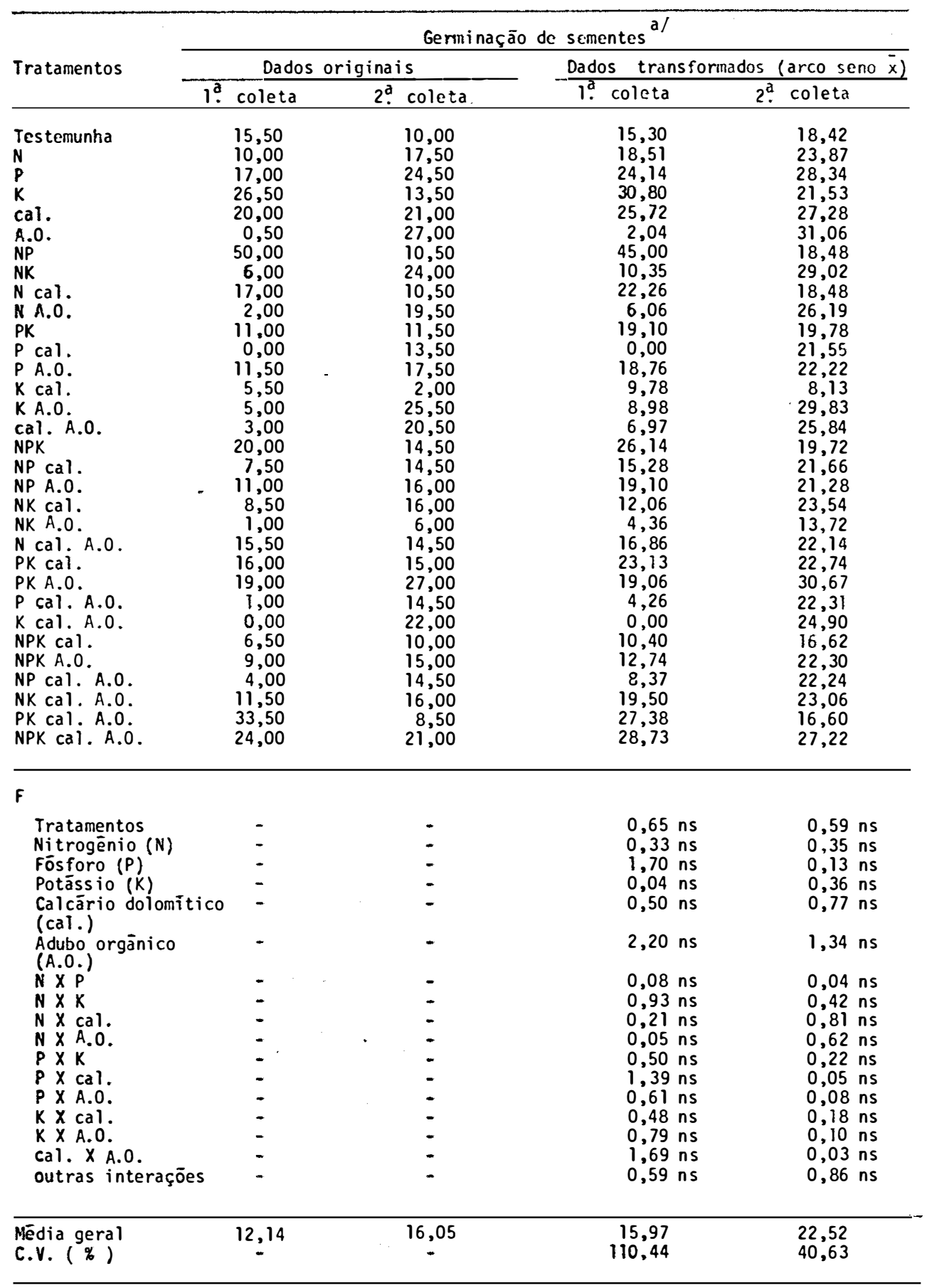

Observações: a/ teste realizado com sementes armazenadas durante 14 meses em cāmara seca; ns = não significativo a $5 \%$ de probabilidade. 
Tabela 9. Médias de porcentagens de germinação de sementes tratadas com àcido sulfūrico, em substrato umedecido com $\mathrm{KNO}_{3}$, nas diferentes parcelas de grama-batatais em duas coletas (dezembro de 1981 e abril de 1982).

\begin{tabular}{|c|c|c|c|c|}
\hline \multirow{3}{*}{ Tratamentos } & \multicolumn{4}{|c|}{ Germinaçāo de sementesal } \\
\hline & \multicolumn{2}{|c|}{ Dados originais } & \multicolumn{2}{|c|}{ Dados transformados (arco seno $\bar{x}$ ) } \\
\hline & coleta & 2. coleta & 1. coleta & 2 coleta \\
\hline $\begin{array}{l}\text { Testemunha } \\
N \\
\text { P } \\
K \\
\text { cal. } \\
\text { AO. } \\
\text { NP } \\
N K \\
N \text { cal. } \\
N \text { A.O. } \\
\text { PK } \\
\text { P cal. } \\
\text { P A.0. } \\
\text { K cal. } \\
\text { K A.0. } \\
\text { Cal. A.0. } \\
\text { NPK } \\
\text { NP cal. } \\
\text { NP A.O. } \\
\text { NK cal: } \\
\text { NK A.O. } \\
\text { N cal. A.0. } \\
\text { PK cal. } \\
\text { PK A.O. } \\
\text { P cal. A.0. } \\
\text { K cal. A.O. } \\
\text { NPK cal. } \\
\text { NPK A.O. } \\
\text { NP cal. A.O. } \\
\text { NK cal. A.O. } \\
\text { PK cal. A.O. } \\
\text { NPK Cal. A.O. }\end{array}$ & $\begin{array}{r}40,50 \\
20,00 \\
40,00 \\
30,00 \\
51,00 \\
40,00 \\
0,00 \\
6,00 \\
56,00 \\
31,50 \\
40,50 \\
35,00 \\
24,00 \\
16,00 \\
21,50 \\
16,50 \\
39,00 \\
24,00 \\
24,50 \\
49,00 \\
8,00 \\
9,00 \\
57,50 \\
21,50 \\
19,50 \\
25,00 \\
44,50 \\
22,50 \\
8,50 \\
48,00 \\
58,50 \\
63,00\end{array}$ & $\begin{array}{r}2,50 \\
0,00 \\
10,50 \\
0,50 \\
0,00 \\
0,00 \\
0,00 \\
0,00 \\
0,00 \\
0,00 \\
0,00 \\
33,50 \\
0,50 \\
0,00 \\
0,00 \\
0,50 \\
0,00 \\
1,00 \\
0,00 \\
2,50 \\
0,00 \\
0,00 \\
0,00 \\
2,00 \\
0,00 \\
0,00 \\
0,50 \\
0,50 \\
0,00 \\
10,00 \\
0,00 \\
12,50\end{array}$ & $\begin{array}{l}39,54 \\
26,68 \\
38,89 \\
31,72 \\
45,66 \\
39,10 \\
0,00 \\
10,35 \\
48,94 \\
33,15 \\
39,12 \\
36,34 \\
27,95 \\
23,46 \\
26,06 \\
17,44 \\
38,64 \\
29,48 \\
29,66 \\
44,42 \\
15,30 \\
12,74 \\
49,70 \\
20,46 \\
19,35 \\
22,50 \\
41,86 \\
20,95 \\
12,06 \\
43,66 \\
50,56 \\
50,20\end{array}$ & 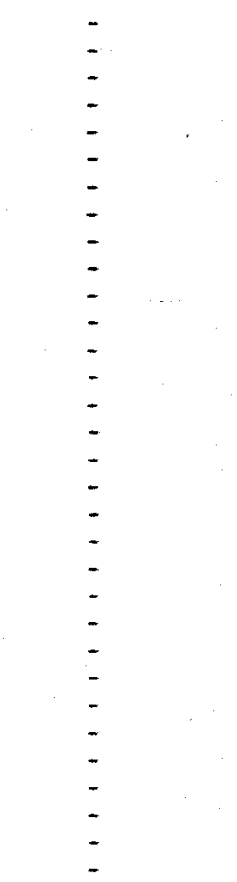 \\
\hline
\end{tabular}

F

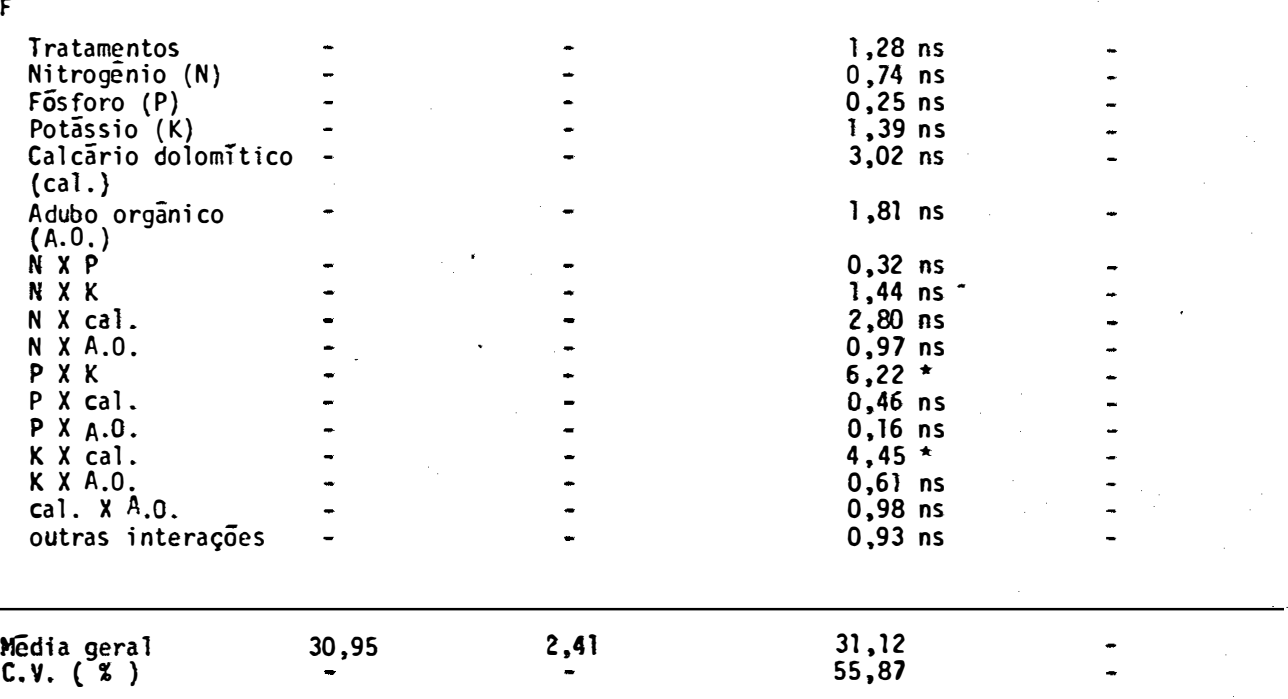

Observaçoes: a/ teste realizado com sementes armazenadas du rante 14 meses em câmara seca; ns = não significativo a $5 \%$ de probabilidade; * = significativo a $5 \%$ de probabilidade. 
Tabela 10. Médias de indices de velocidade de emergência de plāntulas originadas de sementes não tratadas, em substrato umedecido com à gua, e de sementes trata das com ācido sulfūrico, em substrato umedecido com $\mathrm{KNO}_{3}$, nas diferentes parcelas de grama-bata tais em duas coletas (dezembro de 1981 e abril de 1982).

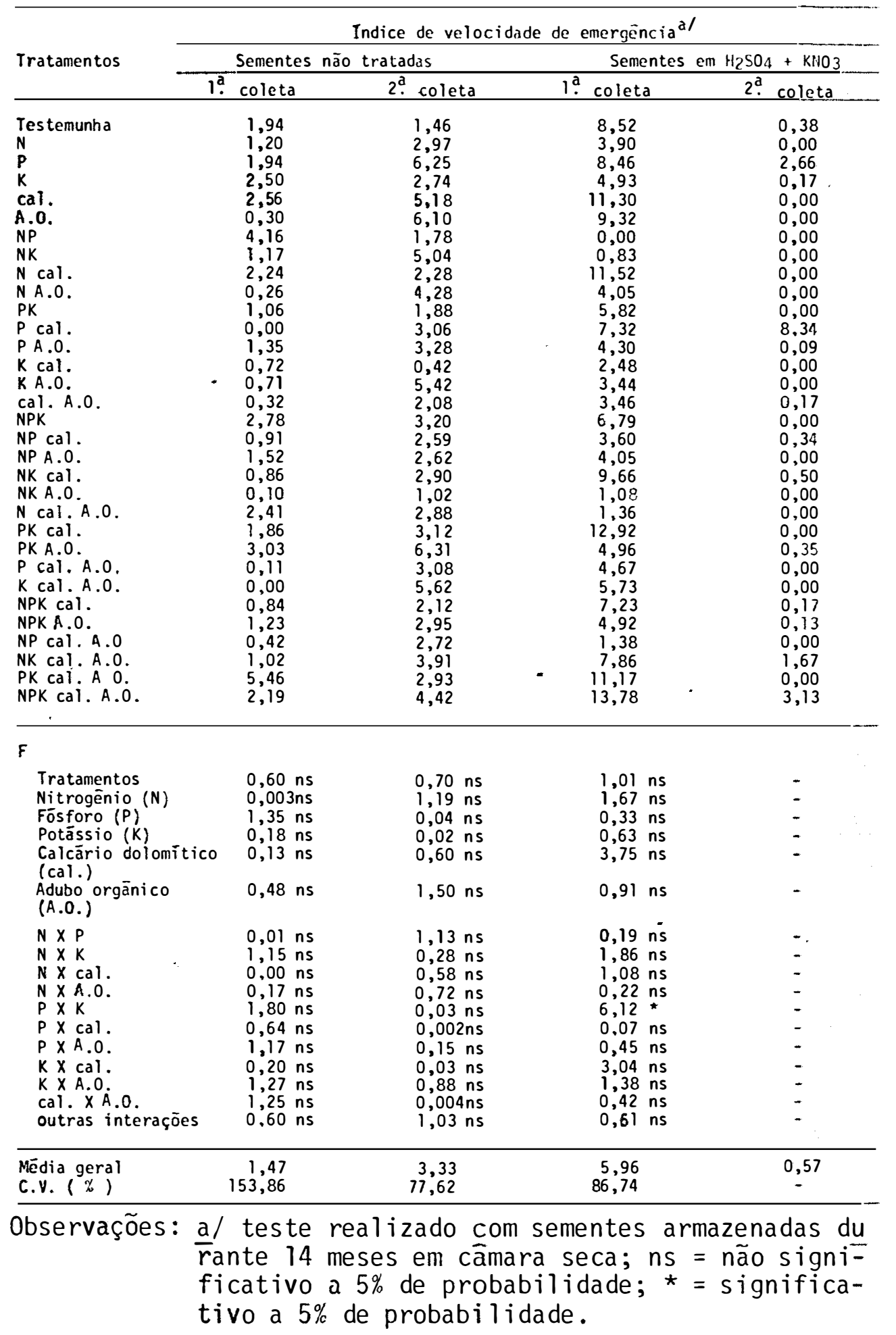


Tabela 11. Médias das concentrações de nitrogênio de folhas e sementes nas diferentes parcelas de grama-bata tais em duas coletas (dezembro de 1981 e abriT de 1982).

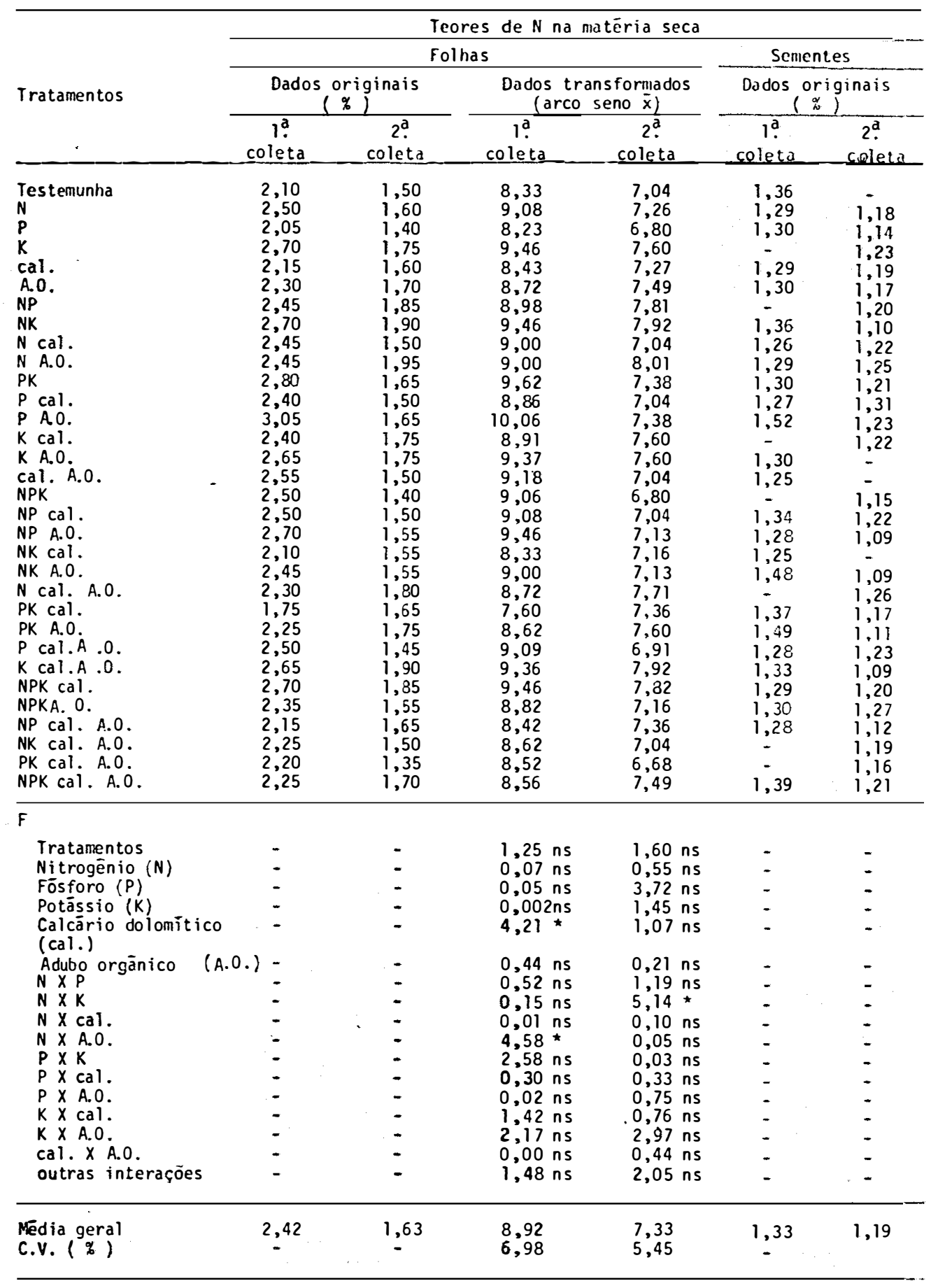

Observações: ns = não significativo a $5 \%$ de probabilidade ; * = significativo a $5 \%$ de probabilidade. 
Tabela 12. Médias das concentrações de fósforo de folhas e sementes nas diferentes parcelas de grama-batatais em duas coletas (dezembro de 1981 e abril de 1982).

\begin{tabular}{|c|c|c|c|c|c|c|}
\hline \multirow{4}{*}{ Tratamentos } & \multicolumn{6}{|c|}{ Teores de $P$ na matéria seca } \\
\hline & \multicolumn{4}{|c|}{ Folhas } & \multicolumn{2}{|c|}{ Sementes } \\
\hline & \multicolumn{2}{|c|}{$\begin{array}{c}\text { Dados originais } \\
(\%)\end{array}$} & \multicolumn{2}{|c|}{$\begin{array}{c}\text { Dados trans formados } \\
\text { (arco seno } \bar{x})\end{array}$} & \multicolumn{2}{|c|}{ Dados originais } \\
\hline & $\begin{array}{c}1^{a} \\
\text { coleta } \\
\end{array}$ & $\begin{array}{l}2 \mathrm{a} \\
\text { coleta }\end{array}$ & $\begin{array}{c}1 \stackrel{a}{.} \\
\text { coleta }\end{array}$ & $\begin{array}{c}2 \mathrm{a} \\
\text { coleta } \\
\end{array}$ & $\begin{array}{c}1^{a} \\
\text { coleta }\end{array}$ & $\begin{array}{c}2 \mathrm{a} \\
\text { coleta }\end{array}$ \\
\hline 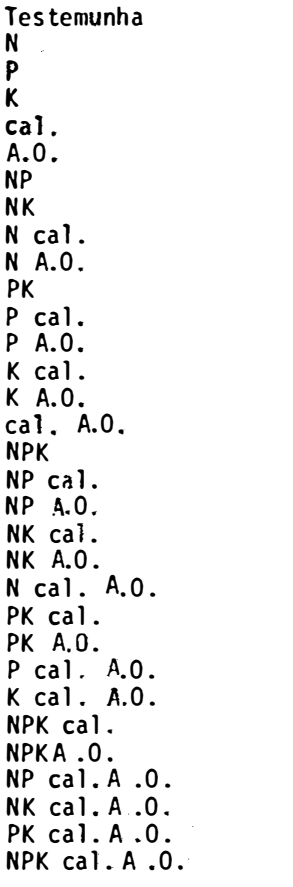 & $\begin{array}{l}0,23 \\
0,19 \\
0,22 \\
0,18 \\
0,25 \\
0,20 \\
0,22 \\
0,20 \\
0,18 \\
0,24 \\
0,21 \\
0,23 \\
0,21 \\
0,20 \\
0,21 \\
0,20 \\
0,20 \\
0,22 \\
0,24 \\
0,20 \\
0,22 \\
0,20 \\
0,21 \\
0,24 \\
0,22 \\
0,24 \\
0,22 \\
0,25 \\
0,24 \\
0,22 \\
0,18 \\
0,22\end{array}$ & $\begin{array}{l}0,08 \\
0,07 \\
0,10 \\
0,07 \\
0,07 \\
0,08 \\
0,12 \\
0,07 \\
0,08 \\
0,11 \\
0,09 \\
0,07 \\
0,11 \\
0,10 \\
0,08 \\
0,08 \\
0,09 \\
0,10 \\
0,08 \\
0,09 \\
0,09 \\
0,08 \\
0,08 \\
0,10 \\
0,08 \\
0,09 \\
0,06 \\
0,09 \\
0,10 \\
0,09 \\
0,10 \\
0,08\end{array}$ & $\begin{array}{l}2,74 \\
2,49 \\
2,66 \\
2,43 \\
2,86 \\
2,59 \\
2,69 \\
2,52 \\
2,40 \\
2,78 \\
2,62 \\
2,75 \\
2,60 \\
2,56 \\
2,62 \\
2,56 \\
2,60 \\
2,68 \\
2,84 \\
2,57 \\
2,66 \\
2,60 \\
2,62 \\
2,84 \\
2,72 \\
2,78 \\
2,72 \\
2,86 \\
2,77 \\
2,66 \\
2,38 \\
2,68\end{array}$ & $\begin{array}{l}1,62 \\
1,51 \\
1,76 \\
1,52 \\
1,51 \\
1,57 \\
1,98 \\
1,52 \\
1,57 \\
1,88 \\
1,66 \\
1,51 \\
1,90 \\
1,80 \\
1,62 \\
1,62 \\
1,72 \\
1,80 \\
1,56 \\
1,72 \\
1,72 \\
1,62 \\
1,62 \\
1,80 \\
1,62 \\
1,71 \\
1,40 \\
1,72 \\
1,76 \\
1,72 \\
1,76 \\
1,60\end{array}$ & $\begin{array}{l}0,24 \\
0,19 \\
0,30 \\
- \\
0,25 \\
0,19 \\
- \\
0,23 \\
0,26 \\
0,21 \\
0,20 \\
0,20 \\
0,26 \\
- \\
0,15 \\
0,26 \\
- \\
0,24 \\
0,20 \\
0,22 \\
0,19 \\
- \\
0,20 \\
0,25 \\
0,24 \\
0,24 \\
0,18 \\
0,20 \\
0,23 \\
= \\
- \\
0,29\end{array}$ & $\begin{array}{l}0,15 \\
0,12 \\
0,11 \\
0,13 \\
0,14 \\
0,12 \\
0,12 \\
0,13 \\
0,16 \\
0,13 \\
0,15 \\
0,14 \\
0,13 \\
- \\
-, 15 \\
0,15 \\
0,14 \\
0,13 \\
0,18 \\
0,112 \\
0,14 \\
0,10 \\
0,14 \\
0,18 \\
0,15 \\
0,14 \\
0,15 \\
0,10 \\
0,12 \\
0,14\end{array}$ \\
\hline \multicolumn{7}{|l|}{$F$} \\
\hline $\begin{array}{l}\text { Tratamentos } \\
\text { Nitrogẽnio }(N) \\
\text { Fósforo }(P) \\
\text { Potāssio }(K) \\
\text { Calcārio dolomitica } \\
\text { (cal.) }\end{array}$ & $\begin{array}{l}- \\
- \\
-\end{array}$ & $\begin{array}{l}- \\
- \\
-\end{array}$ & $\begin{array}{l}0,77 \text { ns } \\
0,04 \text { ns } \\
2,21 \text { ns } \\
0,52 \text { ns } \\
0,07 \text { ns }\end{array}$ & $\begin{array}{l}1,17 \text { ns } \\
0,06 \text { ns } \\
1,97 \text { ns } \\
0,07 \text { ns } \\
1,08 \text { ns }\end{array}$ & $\begin{array}{l}- \\
-\end{array}$ & $\begin{array}{l}- \\
-\end{array}$ \\
\hline 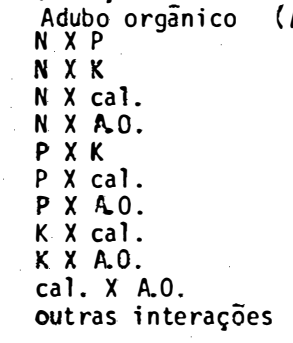 & $\begin{array}{r}(A .0 .)= \\
= \\
= \\
= \\
= \\
= \\
=\end{array}$ & $\begin{array}{l}: \\
\vdots \\
\vdots \\
: \\
: \\
-\end{array}$ & $\begin{array}{l}1,55 \mathrm{~ns} \\
1,90 \mathrm{~ns} \\
0,63 \mathrm{~ns} \\
0,36 \mathrm{~ns} \\
2,55 \mathrm{~ns} \\
0,04 \mathrm{~ns} \\
0,39 \mathrm{~ns} \\
0,14 \mathrm{~ns} \\
0,03 \mathrm{~ns} \\
0,63 \mathrm{~ns} \\
1,79 \mathrm{~ns} \\
0,74 \mathrm{~ns}\end{array}$ & $\begin{array}{l}1,93 \mathrm{~ns} \\
0,31 \mathrm{~ns} \\
2,05 \mathrm{~ns} \\
0,02 \mathrm{~ns} \\
0,11 \mathrm{~ns} \\
2,27 \mathrm{~ns} \\
3,84 \mathrm{~ns} \\
0,34 \mathrm{~ns} \\
1,50 \mathrm{~ns} \\
0,38 \mathrm{~ns} \\
0,002 \mathrm{~ns} \\
1,36 \mathrm{~ns}\end{array}$ & $\begin{array}{l}- \\
- \\
: \\
: \\
- \\
- \\
- \\
-\end{array}$ & $\begin{array}{l}- \\
- \\
- \\
- \\
- \\
- \\
- \\
-\end{array}$ \\
\hline $\begin{array}{l}\text { Média geral } \\
\text { C.V. }\left(\begin{array}{c}\% \\
\text { ( }\end{array}\right.\end{array}$ & 0,22 & 0,09 & $\begin{array}{l}2,65 \\
7,76\end{array}$ & $\begin{array}{r}1,67 \\
10,24\end{array}$ & 0,22 & 0,14 \\
\hline
\end{tabular}

Observação: ns = não significativo a $5 \%$ de probabilidade. 
Tabela 13. Médias das concentrações de potássio de folhas e sementes nas diferentes parcelas de grama-bata tais em duas coletas (dezembro de 1981 e abril de 1982).

\begin{tabular}{|c|c|c|c|c|c|c|}
\hline \multirow{4}{*}{ Tratamentos } & \multicolumn{6}{|c|}{ Teores de $K$ na matéria seca } \\
\hline & \multicolumn{4}{|c|}{ Folhas } & \multicolumn{2}{|c|}{ Sementes } \\
\hline & \multicolumn{2}{|c|}{$\begin{array}{c}\text { Dados originais } \\
(\%)\end{array}$} & \multicolumn{2}{|c|}{$\begin{array}{c}\text { Dados trans formados } \\
\text { (arco seno } \bar{x})\end{array}$} & \multicolumn{2}{|c|}{$\begin{array}{c}\text { Dados originais } \\
(q)\end{array}$} \\
\hline & $\begin{array}{c}1{ }^{\mathrm{a}} \\
\text { coleta }\end{array}$ & $\begin{array}{c}2 e^{\mathrm{a}} \\
\text { coleta }\end{array}$ & $\begin{array}{c}19 \\
\text { coleta }\end{array}$ & $\begin{array}{c}2 . \\
\text { coleta } \\
\end{array}$ & $\begin{array}{c}1^{\mathrm{a}} \\
\text { coleta }\end{array}$ & $\begin{array}{c}2{ }^{a} \\
\text { colcta } \\
\end{array}$ \\
\hline 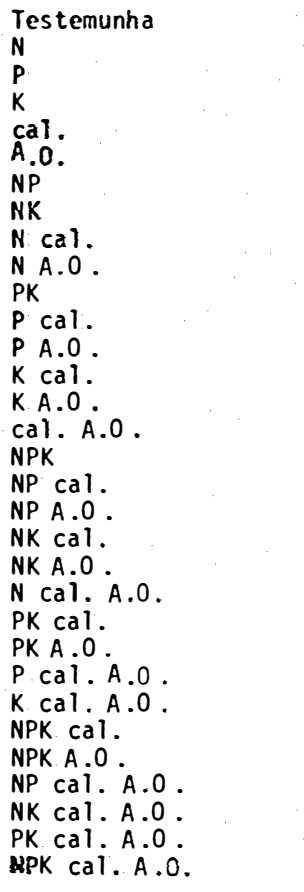 & $\begin{array}{l}2,10 \\
1,98 \\
2,18 \\
1,70 \\
2,04 \\
2,10 \\
2,20 \\
1,68 \\
1,72 \\
2,08 \\
1,84 \\
2,22 \\
2,02 \\
1,71 \\
2,50 \\
2,36 \\
2,06 \\
2,37 \\
1,82 \\
2,02 \\
3,03 \\
1,82 \\
1,92 \\
2,20 \\
2,12 \\
2,70 \\
2,15 \\
2,46 \\
1,58 \\
1,77 \\
1,63 \\
2,10\end{array}$ & $\begin{array}{l}1,68 \\
1,68 \\
1,70 \\
1,52 \\
1,52 \\
1,61 \\
1,56 \\
1,61 \\
1,70 \\
1,75 \\
1,50 \\
1,57 \\
1,60 \\
1,92 \\
1,46 \\
1,35 \\
1,60 \\
1,66 \\
1,37 \\
1,65 \\
1,77 \\
1,38 \\
1,54 \\
1,74 \\
1,42 \\
1,65 \\
1,54 \\
1,43 \\
1,52 \\
1,42 \\
1,59 \\
1,55\end{array}$ & $\begin{array}{l}8,33 \\
8,02 \\
8,42 \\
7,46 \\
8,22 \\
8,33 \\
8,53 \\
7,49 \\
7,46 \\
8,33 \\
7,81 \\
8,53 \\
8,12 \\
7,49 \\
9,08 \\
8,80 \\
8,10 \\
8,82 \\
7,70 \\
8,12 \\
9,97 \\
7,68 \\
7,91 \\
8,52 \\
8,32 \\
9,40 \\
8,42 \\
8,97 \\
7,26 \\
7,68 \\
7,35 \\
8,33\end{array}$ & $\begin{array}{l}7,38 \\
7,49 \\
7,48 \\
7,04 \\
7,04 \\
7,27 \\
7,13 \\
7,27 \\
7,49 \\
7,58 \\
7,04 \\
7,16 \\
7,27 \\
8,02 \\
6,92 \\
6,66 \\
7,26 \\
7,38 \\
6,68 \\
7,38 \\
7,58 \\
6,68 \\
7,16 \\
7,60 \\
6,78 \\
7,34 \\
7,15 \\
6,80 \\
7,02 \\
6,92 \\
7,16 \\
7,04\end{array}$ & $\begin{array}{c}0,23 \\
0,27 \\
0,24 \\
0,24 \\
0,27 \\
- \\
0,24 \\
0,25 \\
0,25 \\
0,24 \\
0,30 \\
0,25 \\
0,26 \\
0,29 \\
0,24 \\
0,25 \\
0,25 \\
0,26 \\
- \\
0,26 \\
0,29 \\
0,29 \\
0,29 \\
0,31 \\
0,27 \\
0,30 \\
- \\
0,28\end{array}$ & $\begin{array}{l}- \\
0,20 \\
0,16 \\
0,15 \\
0,20 \\
0,15 \\
0,13 \\
0,14 \\
0,14 \\
0,19 \\
0,15 \\
0,18 \\
0,17 \\
0,14 \\
- \\
0,19 \\
0,18 \\
0,16 \\
= \\
0,13 \\
0,15 \\
0,13 \\
0,15 \\
0,16 \\
0,23 \\
0,19 \\
0,19 \\
0,18 \\
0,11 \\
0,16 \\
0,17\end{array}$ \\
\hline \multicolumn{7}{|l|}{$F$} \\
\hline 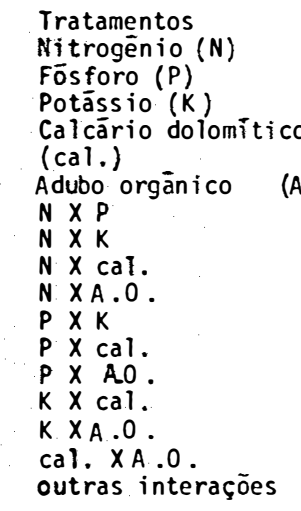 & $\begin{array}{r}= \\
= \\
= \\
= \\
= \\
= \\
= \\
= \\
=\end{array}$ & $\begin{array}{l}= \\
= \\
= \\
= \\
= \\
= \\
= \\
= \\
= \\
=\end{array}$ & $\begin{array}{r}1,75 \mathrm{~ns} \\
0,20 \mathrm{~ns} \\
0,09 \mathrm{~ns} \\
0,22 \mathrm{~ns} \\
1,64 \mathrm{~ns} \\
3,12 \mathrm{~ns} \\
1,74 \mathrm{~ns} \\
4,07 \mathrm{~ns} \\
1,50 \mathrm{~ns} \\
1,10 \mathrm{~ns} \\
0,46 \mathrm{~ns} \\
0,11 \mathrm{~ns} \\
10,67 \star \star \\
0,57 \mathrm{~ns} \\
9,66 \star 6 \\
3,54 \mathrm{~ns} \\
1,04 \mathrm{~ns}\end{array}$ & $\begin{array}{l}0,94 \mathrm{~ns} \\
0,06 \mathrm{~ns} \\
1,20 \mathrm{~ns} \\
0,43 \mathrm{~ns} \\
0,62 \mathrm{~ns} \\
3,87 \mathrm{~ns} \\
1,13 \mathrm{~ns} \\
0,49 \mathrm{~ns} \\
0,002 \mathrm{~ns} \\
0,28 \mathrm{~ns} \\
0,10 \mathrm{~ns} \\
0,10 \mathrm{~ns} \\
0,15 \mathrm{~ns} \\
2,28 \mathrm{~ns} \\
0,80 \mathrm{~ns} \\
2,36 \mathrm{~ns} \\
1,02 \mathrm{~ns}\end{array}$ & $\begin{array}{l}- \\
: \\
- \\
- \\
- \\
- \\
- \\
- \\
- \\
-\end{array}$ & $\begin{array}{l}= \\
= \\
= \\
- \\
= \\
= \\
= \\
- \\
- \\
- \\
-\end{array}$ \\
\hline Média geral & 2,07 & 1,58 & 8,22 & 7,19 & 0,26 & 0,16 \\
\hline C.V. $(\%)$ & - & - & 8,08 & 6,29 & - & - \\
\hline
\end{tabular}

Observações: ns = não significativo a $5 \%$ de probabilidade ; $\star \star=$ significativo a $1 \%$ de probabilidade. 
Tabela 14. Médias das concentrações de cālcio de folhas e se mentes nas diferentes parcelas de grama-batatais em duas coletas (dezembro de 1981 e abril de 1982).

\begin{tabular}{|c|c|c|c|c|c|c|}
\hline \multirow{4}{*}{ Tratanientos } & \multicolumn{6}{|c|}{ Teores de Ca na niatēria seca } \\
\hline & \multicolumn{4}{|c|}{ Folhas } & \multicolumn{2}{|c|}{ Sementes } \\
\hline & \multicolumn{2}{|c|}{$\begin{array}{c}\text { Dados originais } \\
(\%)\end{array}$} & \multicolumn{2}{|c|}{$\begin{array}{l}\text { Dados transformados } \\
\text { (arco seno } \bar{x})\end{array}$} & \multicolumn{2}{|c|}{ Dados originais } \\
\hline & $\begin{array}{c}1 . \\
\text { coleta }\end{array}$ & $\begin{array}{c}2 \stackrel{a}{a}^{\prime} \\
\text { coleta }\end{array}$ & $\begin{array}{c}19 \\
\text { coleta }\end{array}$ & $\begin{array}{c}2 \stackrel{a}{a} \\
\text { coleta }\end{array}$ & $\begin{array}{l}1 \stackrel{a}{ } \\
\text { coleta }\end{array}$ & $\begin{array}{l}2 \mathrm{a} \\
\text { coleta }\end{array}$ \\
\hline 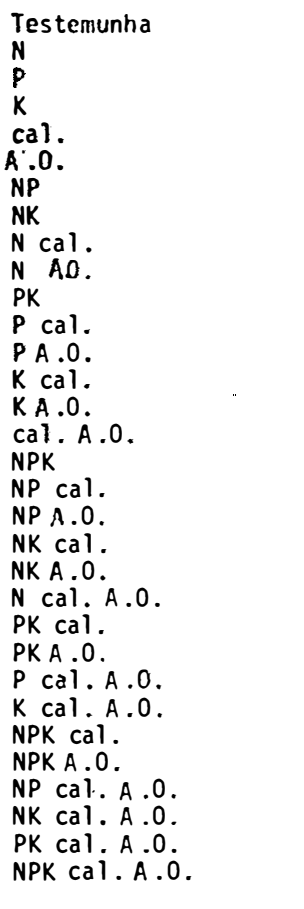 & $\begin{array}{l}0,33 \\
0,35 \\
0,30 \\
0,34 \\
0,34 \\
0,30 \\
0,37 \\
0,31 \\
0,31 \\
0,36 \\
0,34 \\
0,38 \\
0,40 \\
0,36 \\
0,36 \\
0,30 \\
0,35 \\
0,35 \\
0,36 \\
0,32 \\
0,50 \\
0,36 \\
0,35 \\
0,35 \\
0,38 \\
0,47 \\
0,34 \\
0,38 \\
0,38 \\
0,32 \\
0,40 \\
0,32\end{array}$ & $\begin{array}{l}0,30 \\
0,37 \\
0,34 \\
0,38 \\
0,34 \\
0,38 \\
0,34 \\
0,32 \\
0,35 \\
0,34 \\
0,38 \\
0,32 \\
0,35 \\
0,36 \\
0,34 \\
0,31 \\
0,39 \\
0,31 \\
0,35 \\
0,30 \\
0,28 \\
0,40 \\
0,34 \\
0,34 \\
0,33 \\
0,33 \\
0,32 \\
0,34 \\
0,36 \\
0,36 \\
0,38 \\
0,32\end{array}$ & $\begin{array}{l}3,29 \\
3,38 \\
3,14 \\
3,34 \\
3,32 \\
3,16 \\
3,48 \\
3,19 \\
3,19 \\
3,44 \\
3,36 \\
3,56 \\
3,64 \\
3,46 \\
3,46 \\
3,14 \\
3,39 \\
3,39 \\
3,41 \\
3,21 \\
4,05 \\
3,46 \\
3,39 \\
3,39 \\
3,51 \\
3,86 \\
3,34 \\
3,50 \\
3,50 \\
3,24 \\
3,62 \\
3,22\end{array}$ & $\begin{array}{l}3,16 \\
3,48 \\
3,34 \\
3,51 \\
3,34 \\
3,51 \\
3,33 \\
3,21 \\
3,39 \\
3,34 \\
3,56 \\
3,26 \\
3,39 \\
3,46 \\
3,30 \\
3,19 \\
3,58 \\
3,18 \\
3,38 \\
3,16 \\
3,02 \\
3,60 \\
3,32 \\
3,36 \\
3,29 \\
3,29 \\
3,26 \\
3,32 \\
3,44 \\
3,44 \\
3,51 \\
3,24\end{array}$ & $\begin{array}{l}0,06 \\
0,04 \\
0,05 \\
0,06 \\
0,04 \\
0,04 \\
0,06 \\
0,08 \\
0,06 \\
0,05 \\
0,06 \\
0,06 \\
0,07 \\
0,05 \\
0,05 \\
0,07 \\
0,06 \\
0,06 \\
0,06 \\
0,06 \\
0,06 \\
0,07 \\
0,05 \\
0,06 \\
= \\
0,06 \\
0,06\end{array}$ & $\begin{array}{l}0,06 \\
0,06 \\
0,05 \\
0,05 \\
0,06 \\
0,05 \\
0,06 \\
0,05 \\
0,07 \\
0,05 \\
0,08 \\
0,06 \\
0,05 \\
- \\
0,07 \\
0,06 \\
0,06 \\
0,06 \\
0,06 \\
0,05 \\
0,05 \\
0,05 \\
0,05 \\
0,07 \\
0,05 \\
0,06 \\
0,04 \\
0,05 \\
0,06\end{array}$ \\
\hline \multicolumn{7}{|l|}{$F$} \\
\hline $\begin{array}{l}\text { Tratamentos } \\
\text { Nitrogénio }(N) \\
\text { Fósforo }(P) \\
\text { Potāssio }(K) \\
\text { Calcário dolomítico } \\
\text { (cal.) }\end{array}$ & $\begin{array}{l}- \\
- \\
-\end{array}$ & $\begin{array}{l}= \\
= \\
=\end{array}$ & $\begin{array}{l}1,37 \text { ns } \\
0,07 \text { ns } \\
0,49 \text { ns } \\
1,13 \text { ns } \\
0,06 \text { ns }\end{array}$ & $\begin{array}{l}0,87 \text { ns } \\
0,25 \text { ns } \\
0,19 \text { ns } \\
0,02 \text { ns } \\
0,26 \text { ns }\end{array}$ & $\begin{array}{l}- \\
- \\
-\end{array}$ & $\begin{array}{l}- \\
-\end{array}$ \\
\hline 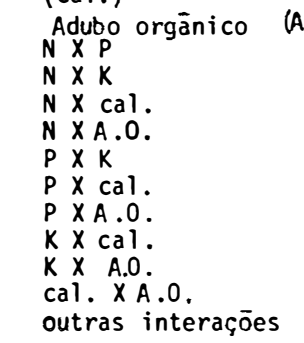 & $\begin{array}{r}(A .0 .)= \\
= \\
= \\
= \\
= \\
= \\
= \\
=\end{array}$ & 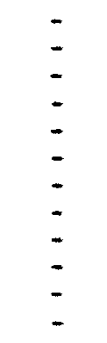 & $\begin{array}{l}5,10 \star \\
0,27 \mathrm{~ns} \\
1,69 \mathrm{~ns} \\
6,08 \star \\
0,10 \mathrm{~ns} \\
3,79 \mathrm{~ns} \\
0,43 \mathrm{~ns} \\
0,50 \mathrm{~ns} \\
0,23 \mathrm{~ns} \\
1,43 \mathrm{~ns} \\
0,64 \mathrm{~ns} \\
1,37 \mathrm{~ns}\end{array}$ & $\begin{array}{l}0,01 \mathrm{~ns} \\
0,04 \mathrm{~ns} \\
4,45 \star \\
0,41 \mathrm{~ns} \\
0,09 \mathrm{~ns} \\
1,96 \mathrm{~ns} \\
1,70 \mathrm{~ns} \\
0,02 \mathrm{~ns} \\
0,004 \mathrm{~ns} \\
2,17 \mathrm{~ns} \\
1,96 \mathrm{~ns} \\
0,89 \mathrm{~ns}\end{array}$ & $\begin{array}{l}- \\
- \\
- \\
- \\
- \\
- \\
- \\
-\end{array}$ & $\begin{array}{l}- \\
- \\
- \\
- \\
- \\
- \\
-\end{array}$ \\
\hline Média geral & 0,36 & 0,34 & 3,41 & 3,35 & 0,06 & 0,06 \\
\hline C.V. (\%) & - & - & 7,05 & 6,21 & - & - \\
\hline
\end{tabular}

Observações: ns = não significativo a $5 \%$ de probabilidade; * = significativo a $5 \%$ de probabilidade. 
Tabela 15. Médias das concentrações de magnésio de folhas e sementes nas diferentes parcelas de grama-bata tais em duas coletas (dezembro de 1981 e abriT de 1982).

\begin{tabular}{|c|c|c|c|c|c|c|}
\hline \multirow{4}{*}{ Tratamentos } & \multicolumn{4}{|c|}{ Teores de Mg na matēria seca } & \multirow{2}{*}{\multicolumn{2}{|c|}{ Sementes }} \\
\hline & \multicolumn{4}{|c|}{ Folhas } & & \\
\hline & \multicolumn{2}{|c|}{ Dados originais } & \multicolumn{2}{|c|}{$\begin{array}{l}\text { Dados transforniados } \\
(\text { arco seno } \bar{x})\end{array}$} & \multicolumn{2}{|c|}{ Dados originais } \\
\hline & $\begin{array}{l}l^{a} \\
\text { coleta }\end{array}$ & $\begin{array}{c}2 ! \\
\text { coleta }\end{array}$ & $\begin{array}{c}1 \mathrm{a} \\
\text { coleta } \\
\end{array}$ & coleta & coleta & coleta \\
\hline 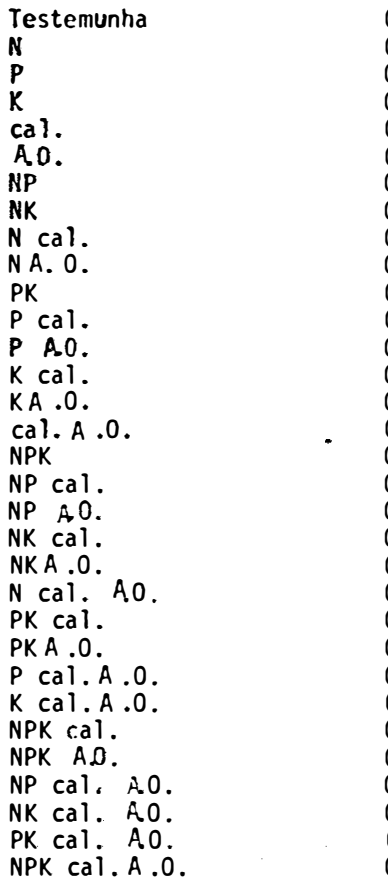 & $\begin{array}{l}0,27 \\
0,24 \\
0,26 \\
0,22 \\
0,27 \\
0,24 \\
0,25 \\
0,20 \\
0,21 \\
0,26 \\
0,27 \\
0,24 \\
0,26 \\
0,24 \\
0,26 \\
0,24 \\
0,22 \\
0,22 \\
0,24 \\
0,24 \\
0,26 \\
0,26 \\
0,26 \\
0,28 \\
0,28 \\
0,30 \\
0,26 \\
0,26 \\
0,26 \\
0,27 \\
0,33 \\
0,26\end{array}$ & $\begin{array}{l}0,34 \\
0,31 \\
0,38 \\
0,30 \\
0,34 \\
0,40 \\
0,30 \\
0,26 \\
0,30 \\
0,32 \\
0,30 \\
0,32 \\
0,37 \\
0,28 \\
0,34 \\
0,33 \\
0,34 \\
0,31 \\
0,34 \\
0,36 \\
0,27 \\
0,38 \\
0,37 \\
0,34 \\
0,40 \\
0,30 \\
0,34 \\
0,36 \\
0,39 \\
0,39 \\
0,36 \\
0,38\end{array}$ & $\begin{array}{l}2,98 \\
2,78 \\
2,90 \\
2,66 \\
2,98 \\
2,83 \\
2,87 \\
2,56 \\
2,62 \\
2,90 \\
2,98 \\
2,84 \\
2,92 \\
2,78 \\
2,89 \\
2,78 \\
2,72 \\
2,72 \\
2,84 \\
2,84 \\
2,92 \\
2,89 \\
2,92 \\
3,06 \\
3,06 \\
3,12 \\
2,90 \\
2,90 \\
2,92 \\
2,98 \\
3,28 \\
2,90\end{array}$ & $\begin{array}{l}3,34 \\
3,19 \\
3,51 \\
3,16 \\
3,34 \\
3,60 \\
3,10 \\
2,95 \\
3,15 \\
3,21 \\
3,16 \\
3,21 \\
3,49 \\
3,06 \\
3,36 \\
3,29 \\
3,34 \\
3,18 \\
3,32 \\
3,46 \\
2,96 \\
3,50 \\
3,48 \\
3,36 \\
3,60 \\
3,13 \\
3,32 \\
3,44 \\
3,58 \\
3,58 \\
3,41 \\
3,51\end{array}$ & $\begin{array}{l}0,08 \\
0,08 \\
0,08 \\
0,08 \\
0,08 \\
0,08 \\
0,08 \\
0,07 \\
0,06 \\
0,08 \\
0,08 \\
0,07 \\
0,09 \\
0,08 \\
0,08 \\
0,07 \\
0,07 \\
0,09 \\
0,08 \\
0,08 \\
0,08 \\
0,07 \\
0,08 \\
0,08 \\
- \\
0,08\end{array}$ & $\begin{array}{l}0,09 \\
0,08 \\
0,07 \\
0,08 \\
0,08 \\
0,07 \\
0,08 \\
0,08 \\
0,09 \\
0,08 \\
0,09 \\
0,08 \\
0,07 \\
= \\
0,09 \\
0,08 \\
0,08 \\
0,06 \\
0,08 \\
0,07 \\
0,06 \\
0,08 \\
0,08 \\
0,09 \\
0,08 \\
0,08 \\
0,05 \\
0,07 \\
0,08\end{array}$ \\
\hline \multicolumn{7}{|l|}{$F$} \\
\hline 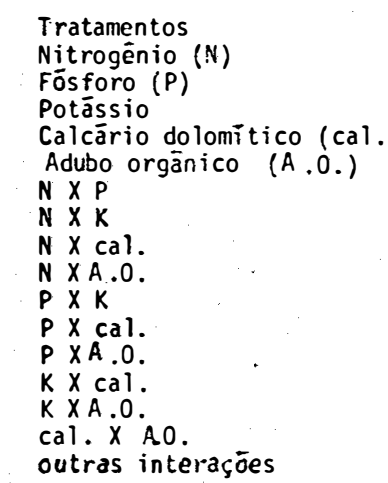 & $\begin{array}{l}- \\
= \\
= \\
. \\
= \\
= \\
= \\
= \\
= \\
= \\
=\end{array}$ & $\begin{array}{l}- \\
: \\
: \\
: \\
: \\
: \\
: \\
: \\
= \\
=\end{array}$ & $\begin{array}{l}1,83 \mathrm{~ns} \\
8,40 \star \star \\
4,09 \mathrm{~ns} \\
0,92 \mathrm{~ns} \\
1,86 \mathrm{~ns} \\
12,52 \star \star \\
1,31 \mathrm{~ns} \\
0,15 \mathrm{~ns} \\
0,21 \mathrm{~ns} \\
0,33 \mathrm{~ns} \\
0,99 \mathrm{~ns} \\
0,02 \mathrm{~ns} \\
0,02 \mathrm{~ns} \\
4,09 \mathrm{~ns} \\
4,30 \star \\
0,74 \mathrm{~ns} \\
1,12 \mathrm{~ns}\end{array}$ & $\begin{array}{l}1,55 \mathrm{~ns} \\
0,75 \mathrm{~ns} \\
4,28 \star \\
1,27 \mathrm{~ns} \\
2,38 \mathrm{~ns} \\
8,15 \star \star \\
0,04 \mathrm{~ns} \\
3,53 \mathrm{~ns} \\
7,10 \star \\
0,27 \mathrm{~ns} \\
1,41 \mathrm{~ns} \\
0,03 \mathrm{~ns} \\
0,22 \mathrm{~ns} \\
1,70 \mathrm{~ns} \\
0,79 \mathrm{~ns} \\
0,27 \mathrm{~ns} \\
1,06 \mathrm{~ns}\end{array}$ & $\begin{array}{l}- \\
- \\
: \\
: \\
= \\
- \\
- \\
- \\
- \\
-\end{array}$ & $\begin{array}{l}- \\
: \\
: \\
: \\
: \\
: \\
: \\
: \\
-\end{array}$ \\
\hline $\begin{array}{l}\text { Mëdia geral } \\
\text { C.v. }(\%)\end{array}$ & 0,25 & 0,34 & $\begin{array}{l}2,88 \\
5,15\end{array}$ & $\begin{array}{l}3,32 \\
6,31\end{array}$ & 0,08 & 0,08 \\
\hline
\end{tabular}

Observações: ns = não significativo a $5 \%$ de probabilidade ; * = significativo a $5 \%$ de probabilidade; $* \star=$ = significativo a $1 \%$ de probabilidade. 
Tabela 16. Médias das concentrações de enxofre de folhas e se mentes nas diferentes parcelas de grama - batatais em duas coletas (dezembro de 1981 e abril de 1982).

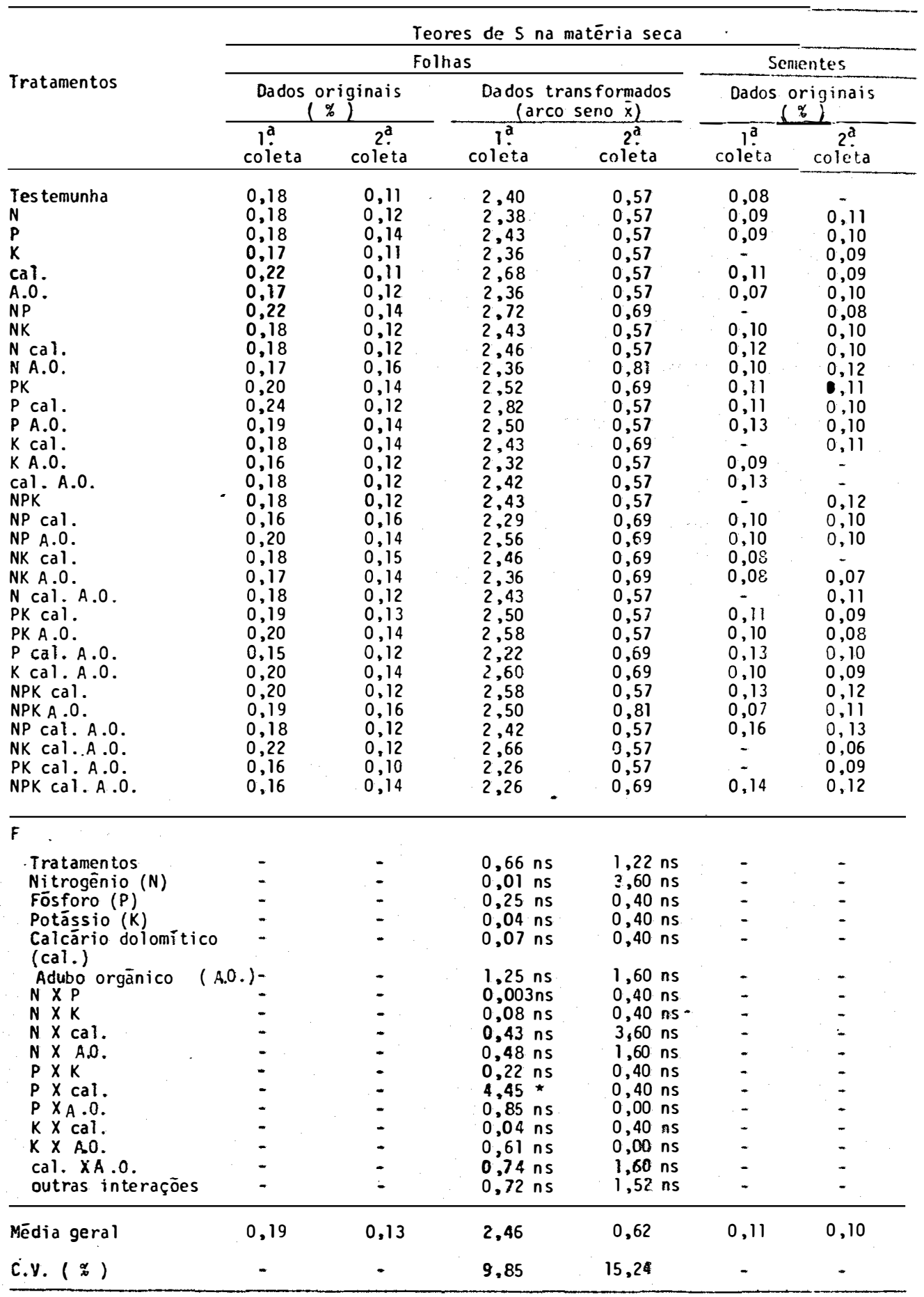

Observações: $n s=$ não significativo a $5 \%$ de probabilidade ; * = significativo a $5 \%$ de probabilidade. 
Tabe la 17. Médias dos teores de boro de folhas e sementes nas diferentes parcelas de grama-batatais em duas coletas (dezembro de 1981 e abril de 1982).

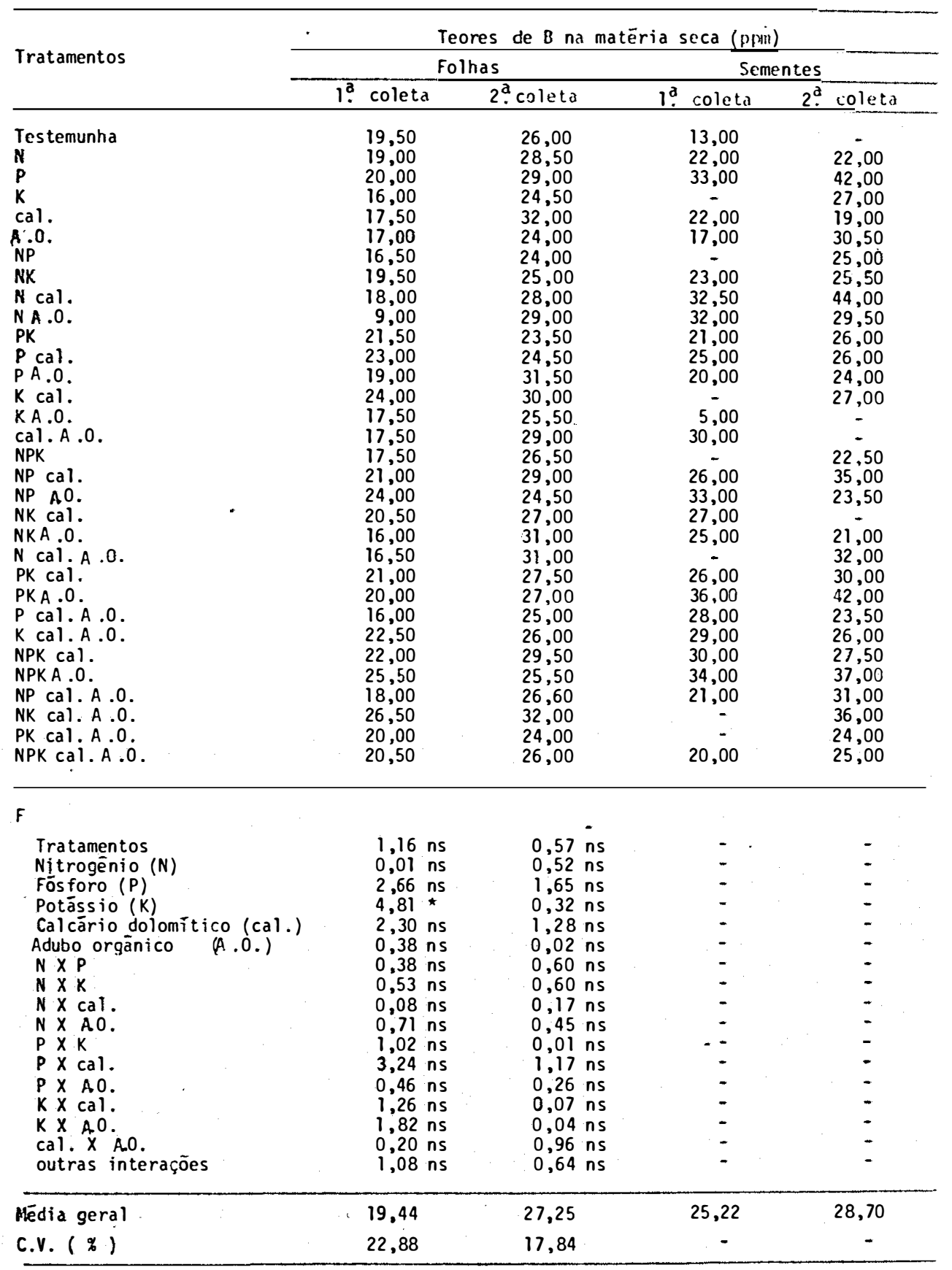

Observações: $n s=$ nã significativo a $5 \%$ de probabilidade; * = significativo a $5 \%$ de probabilidade. 
Tabela 18. Médias dos teores de cobre de folhas e sementes nas diferentes parcelas de grama-batatais em duas coletas (dezembro de 1981 e abril de 1982).

\begin{tabular}{|c|c|c|c|c|}
\hline \multirow{3}{*}{ Tratamentos } & \multicolumn{4}{|c|}{ Teores de Cu na matéria seca (ppon) } \\
\hline & \multicolumn{2}{|c|}{ Folhas } & \multicolumn{2}{|c|}{ Sementes } \\
\hline & 1 . coleta & 2. coleta & 1 . coleta & $2 \mathrm{a}$ colctat \\
\hline 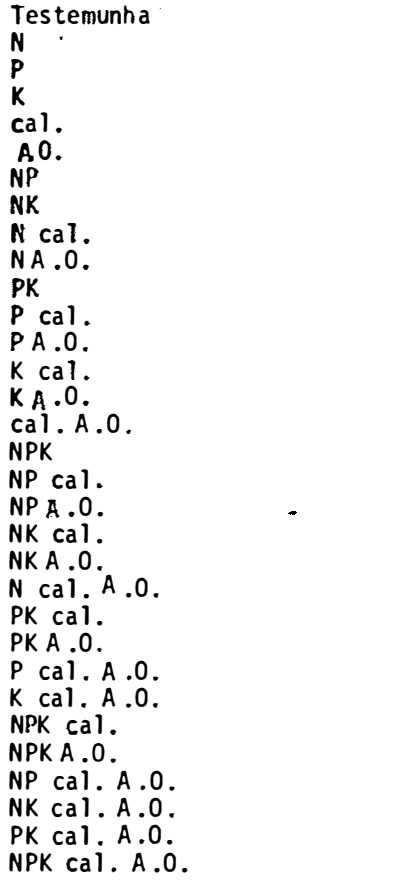 & $\begin{array}{l}11,00 \\
15,50 \\
10,00 \\
12,00 \\
19,00 \\
13,50 \\
12,00 \\
20,00 \\
14,00 \\
14,00 \\
20,00 \\
19,00 \\
11,50 \\
20,50 \\
15,50 \\
17,00 \\
10,00 \\
15,00 \\
13,50 \\
10,50 \\
13,50 \\
11,00 \\
11,00 \\
11,00 \\
10,50 \\
14,50 \\
10,50 \\
13,00 \\
11,00 \\
12,50 \\
13,00 \\
9,50\end{array}$ & $\begin{array}{r}7,50 \\
7,50 \\
7,50 \\
5,50 \\
7,00 \\
8,00 \\
10,00 \\
6,00 \\
8,50 \\
10,50 \\
6,00 \\
8,50 \\
7,00 \\
10,00 \\
7,00 \\
6,50 \\
8,50 \\
9,00 \\
5,00 \\
8,00 \\
7,50 \\
5,50 \\
7,50 \\
8,50 \\
8,50 \\
8,00 \\
7,50 \\
6,00 \\
6,00 \\
7,00 \\
7,50 \\
8,00\end{array}$ & $\begin{array}{c}9,00 \\
11,00 \\
9,00 \\
1,00 \\
11,00 \\
9,00 \\
13,00 \\
6,00 \\
7,50 \\
8,00 \\
7,50 \\
10,00 \\
-, 00 \\
11,00 \\
12,00 \\
9,00 \\
6,00 \\
5,00 \\
- \\
10,50 \\
10,00 \\
9,50 \\
9,00 \\
5,00 \\
9,00 \\
11,00 \\
- \\
10,00\end{array}$ & $\begin{array}{r}14,00 \\
12,50 \\
8,00 \\
12,00 \\
12,50 \\
12,00 \\
8,00 \\
8,00 \\
13,00 \\
11,50 \\
17,00 \\
8,00 \\
10,00 \\
- \\
12,50 \\
9,00 \\
10,00 \\
- \\
7,00 \\
13,00 \\
14,00 \\
12,00 \\
14,00 \\
8,00 \\
12,50 \\
13,00 \\
14,00 \\
10,00 \\
9,00 \\
13,50\end{array}$ \\
\hline \multicolumn{5}{|l|}{$\mathrm{F}$} \\
\hline 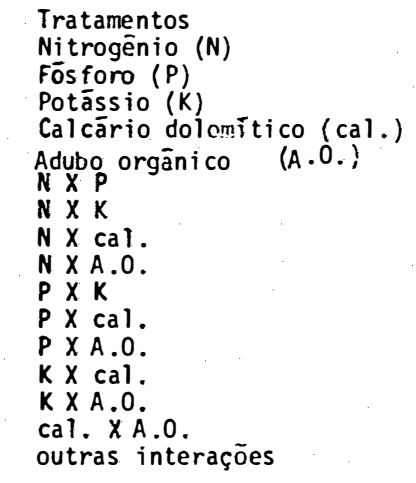 & $\begin{array}{l}0,89 \mathrm{~ns} \\
1,45 \mathrm{~ns} \\
2,95 \mathrm{~ns} \\
0,00 \mathrm{~ns} \\
0,02 \mathrm{~ns} \\
1,71 \mathrm{~ns} \\
0,001 \mathrm{~ns} \\
0,41 \mathrm{~ns} \\
3,70 \mathrm{~ns} \\
0,11 \mathrm{~ns} \\
0,19 \mathrm{~ns} \\
0,08 \mathrm{~ns} \\
0,03 \mathrm{~ns} \\
2,14 \mathrm{~ns} \\
0,01 \mathrm{~ns} \\
0,63 \mathrm{~ns} \\
0,94 \mathrm{~ns}\end{array}$ & $\begin{array}{l}0,87 \mathrm{~ns} \\
0,00 \mathrm{~ns} \\
0,02 \mathrm{~ns} \\
0,25 \mathrm{~ns} \\
0,38 \mathrm{~ns} \\
0,98 \mathrm{~ns} \\
0,06 \mathrm{~ns} \\
0,14 \mathrm{~ns} \\
0,98 \mathrm{~ns} \\
1,86 \mathrm{~ns} \\
0,00 \mathrm{~ns} \\
0,14 \mathrm{~ns} \\
0,98 \mathrm{~ns} \\
2,22 \mathrm{~ns} \\
1,25 \mathrm{~ns} \\
1,54 \mathrm{~ns} \\
1,08 \mathrm{~ns}\end{array}$ & 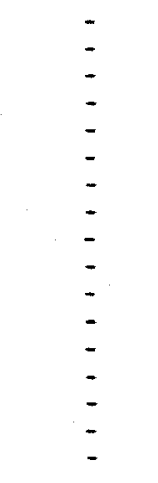 & $\begin{array}{l}: \\
: \\
: \\
\vdots \\
\vdots \\
: \\
: \\
: \\
:\end{array}$ \\
\hline Media geral & 13,58 & 7,53 & 9,00 & 11,36 \\
\hline C.Y. $(*)$ & 35,90 & 26,76 & - & $=$ \\
\hline
\end{tabular}

Observação: ns = não significativo a $5 \%$ de probabilidade. 
Tabela 19. Mëdias dos teores de ferro de folhas e sementes nas diferentes parcelas de grama - batatais em duas coletas (dezembro de 1981 e abril de 1982).

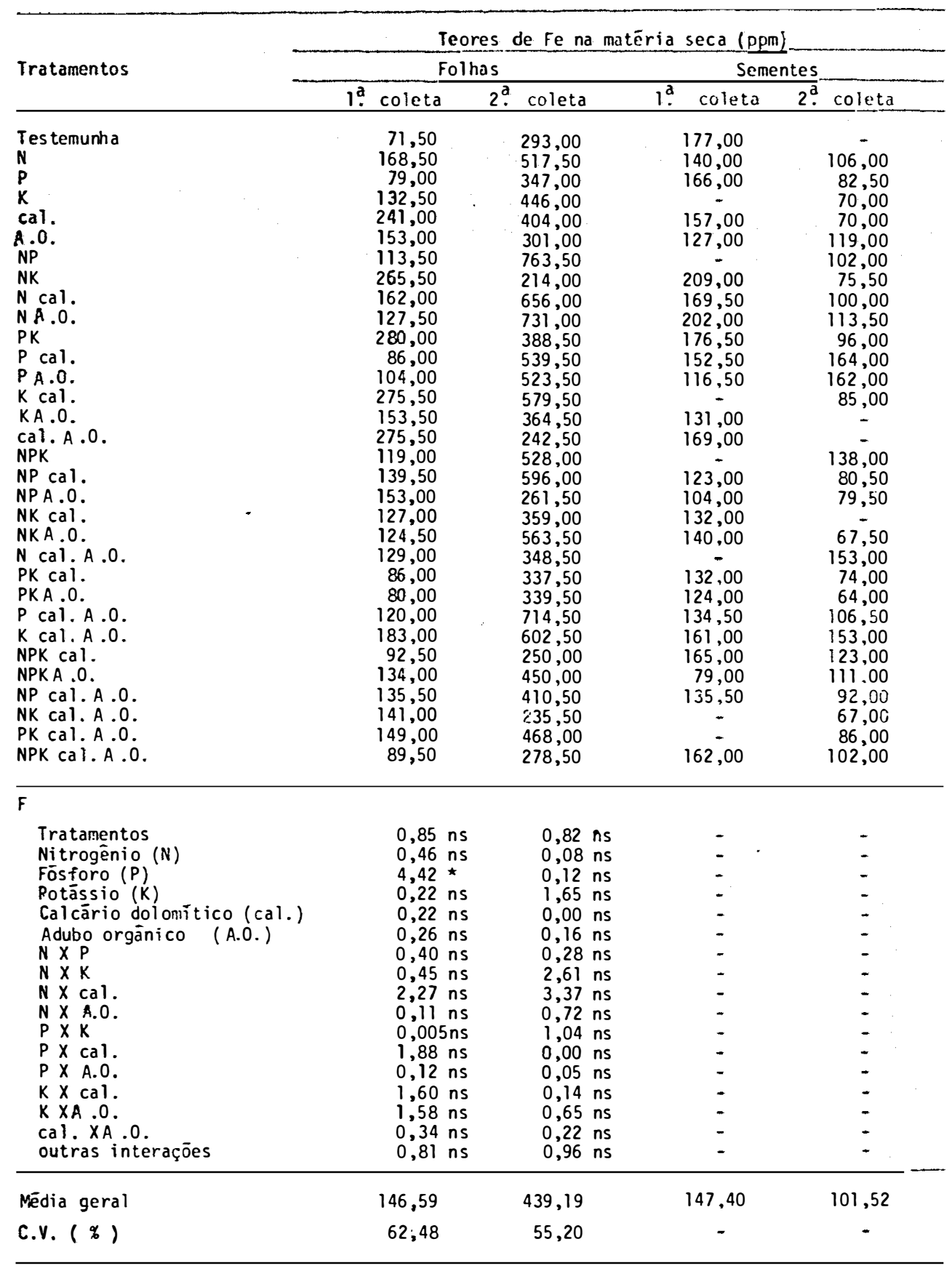

Observações: $n s=$ não significativo a $5 \%$ de probabilidade; * = significativo a $5 \%$ de probabilidade. 
Tabela 20. Médias dos teores de manganês de folhas e semen tes nas diferentes parcelas de grama-batatais em duas coletas (dezembro de 1981 e abril de 1982).

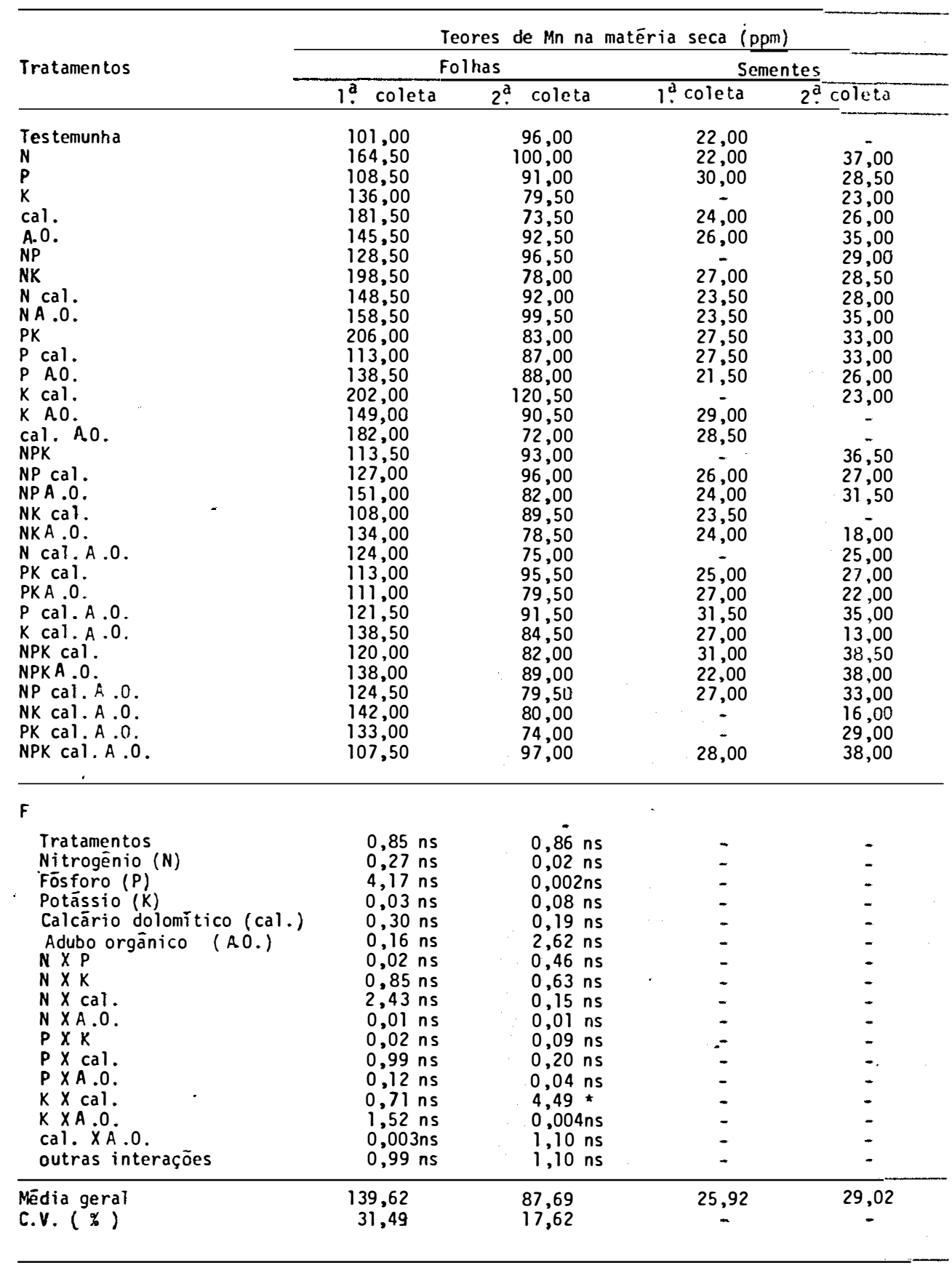

Observações: ns = não significativo a $5 \%$ de probabilidade ; * = significativo a $5 \%$ de probabilidade. 
Tabela 21. Médias dos teores de zinco de folhas e sementes nas diferentes parcelas de grama-batatais em duas coletas (dezembro de 1981 e abril de 1982).

\begin{tabular}{|c|c|c|c|c|c|}
\hline \multirow{3}{*}{ Tratamentos } & \multicolumn{5}{|c|}{ Teores de $2 n$ na matēria seca (ppm) } \\
\hline & \multicolumn{2}{|c|}{ Folhas } & \multicolumn{3}{|c|}{ Sementes } \\
\hline & 1. coleta & 2. coleta & 19 & coleta & 2. coleta \\
\hline 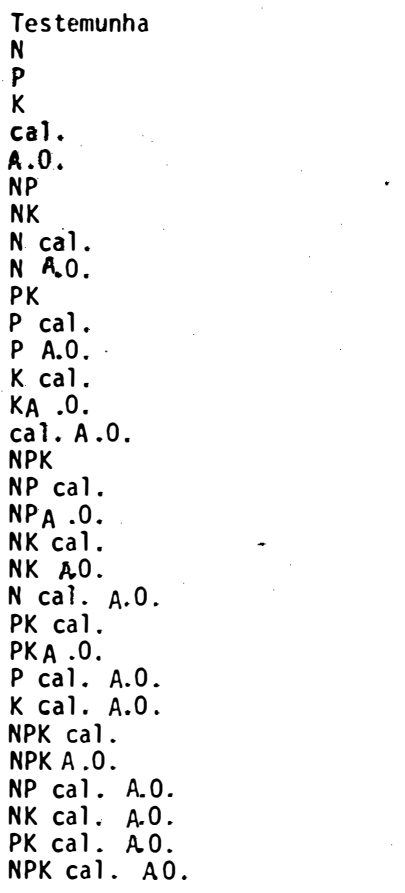 & $\begin{array}{l}21,50 \\
25,50 \\
20,50 \\
24,00 \\
28,50 \\
23,00 \\
20,00 \\
32,50 \\
22,00 \\
26,00 \\
30,00 \\
22,00 \\
19,50 \\
34,00 \\
25,00 \\
35,00 \\
18,50 \\
27,50 \\
22,50 \\
20,50 \\
22,50 \\
23,00 \\
19,50 \\
19,50 \\
22,50 \\
27,00 \\
20,50 \\
21,50 \\
20,00 \\
22,00 \\
20,50 \\
18,00\end{array}$ & $\begin{array}{r}12,00 \\
14,50 \\
14,00 \\
11,00 \\
13,00 \\
10,50 \\
15,50 \\
10,50 \\
16,50 \\
21,50 \\
9,50 \\
13,00 \\
12,00 \\
20,00 \\
11,50 \\
13,00 \\
12,50 \\
16,00 \\
10,00 \\
13,50 \\
12,50 \\
11,00 \\
11,00 \\
11,50 \\
13,00 \\
12,00 \\
12,50 \\
10,50 \\
14,00 \\
15,00 \\
10,50 \\
17,50\end{array}$ & & $\begin{array}{l}33,00 \\
32,00 \\
32,00 \\
40,00 \\
41,00 \\
39,00 \\
33,00 \\
33,50 \\
28,50 \\
36,50 \\
31,50 \\
28,00 \\
25,00 \\
33,00 \\
32,00 \\
28,00 \\
27,00 \\
31,50 \\
30,00 \\
34,00 \\
37,00 \\
35,00 \\
32,00 \\
29,00 \\
- \\
32,00\end{array}$ & $\begin{array}{l}28,00 \\
24,50 \\
26,00 \\
25,00 \\
29,50 \\
24,00 \\
27,00 \\
29,00 \\
32,00 \\
26,50 \\
28,00 \\
27,00 \\
23,00 \\
5 \\
32,50 \\
29,00 \\
28,00 \\
24,50 \\
29,00 \\
22,00 \\
23,00 \\
24,50 \\
45,00 \\
33,50 \\
30,00 \\
30,00 \\
20,00 \\
25,00 \\
32,00\end{array}$ \\
\hline \multicolumn{6}{|l|}{$F$} \\
\hline 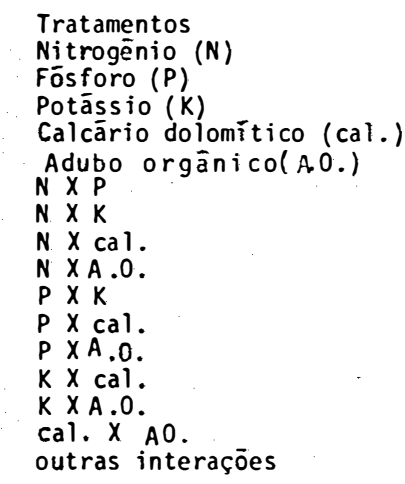 & $\begin{array}{l}0,82 \mathrm{~ns} \\
1,12 \mathrm{~ns} \\
6,24 \star \\
0,02 \mathrm{~ns} \\
0,14 \mathrm{~ns} \\
0,49 \mathrm{~ns} \\
0,44 \mathrm{~ns} \\
0,40 \mathrm{~ns} \\
2,22 \mathrm{~ns} \\
0,02 \mathrm{~ns} \\
0,12 \mathrm{~ns} \\
0,24 \mathrm{~ns} \\
0,12 \mathrm{~ns} \\
1,45 \mathrm{~ns} \\
0,98 \mathrm{~ns} \\
0,05 \mathrm{~ns} \\
0,75 \mathrm{~ns}\end{array}$ & $\begin{array}{l}1,10 \mathrm{~ns} \\
2,95 \mathrm{~ns} \\
0,98 \mathrm{~ns} \\
1,41 \mathrm{~ns} \\
2,11 \mathrm{~ns} \\
0,35 \mathrm{~ns} \\
0,02 \mathrm{~ns} \\
0,53 \mathrm{~ns} \\
0,11 \mathrm{~ns} \\
0,44 \mathrm{~ns} \\
0,16 \mathrm{~ns} \\
0,02 \mathrm{~ns} \\
0,004 \mathrm{~ns} \\
2,31 \mathrm{~ns} \\
0,44 \mathrm{~ns} \\
0,44 \mathrm{~ns} \\
1,45 \mathrm{~ns}\end{array}$ & & $\begin{array}{l}= \\
= \\
= \\
= \\
= \\
- \\
- \\
- \\
-\end{array}$ & 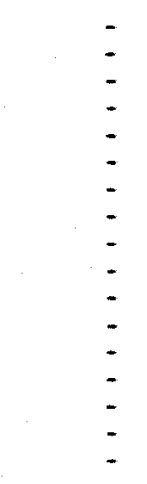 \\
\hline $\begin{array}{l}\text { Média geral } \\
\text { C.V. }(\%)\end{array}$ & $\begin{array}{l}23,58 \\
29,50\end{array}$ & $\begin{array}{l}13,16 \\
28,76\end{array}$ & & 32,94 & $\begin{array}{c}27,77 \\
-\end{array}$ \\
\hline
\end{tabular}

Observações: $n s=$ não significativo a $5 \%$ de probabilidade; * = significativo a $5 \%$ de probabilidade. 
Tabela 22. Médias das relações $\mathrm{K} / \mathrm{Mg}, \mathrm{K} / \mathrm{Ca}+\mathrm{Mg}$ e $\mathrm{Ca} / \mathrm{Mg}$ de folhas nas diferentes parcelas de grama-batatais em duas coletas (dezembro de 1981 e abril de 1982).

\begin{tabular}{|c|c|c|c|c|c|c|}
\hline \multirow{3}{*}{ Tratamentos } & \multicolumn{6}{|c|}{ Relações entre nutrientes na matēria seca de folhas } \\
\hline & \multicolumn{2}{|c|}{$\mathrm{K} / \mathrm{Mg}$} & \multicolumn{2}{|c|}{$\mathrm{K} / \mathrm{Ca}+\mathrm{Mg}$} & \multicolumn{2}{|c|}{$\mathrm{Ca} / \mathrm{Mg}$} \\
\hline & $\begin{array}{c}19 \\
\text { coleta }\end{array}$ & $\begin{array}{c}2 ! \\
\text { coleta }\end{array}$ & $\begin{array}{l}l^{a} \\
\text { coleta }\end{array}$ & $\begin{array}{l}2 . \\
\text { coleta }\end{array}$ & $\begin{array}{l}\text { ad } \\
\text { coleta }\end{array}$ & $\begin{array}{c}2^{a} \\
\text { coleta }\end{array}$ \\
\hline 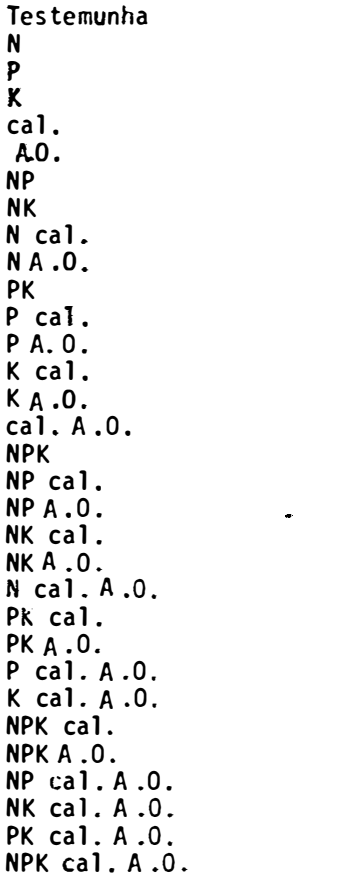 & $\begin{array}{r}7,80 \\
8,42 \\
8,56 \\
7,86 \\
7,54 \\
8,73 \\
8,78 \\
8,40 \\
8,14 \\
8,16 \\
6,80 \\
9,05 \\
7,79 \\
7,28 \\
10,02 \\
10,30 \\
9,14 \\
10,55 \\
7,41 \\
8,31 \\
11,64 \\
7,13 \\
7,42 \\
7,85 \\
7,47 \\
9,19 \\
8,45 \\
9,68 \\
6,18 \\
6,52 \\
5,42 \\
8,21\end{array}$ & $\begin{array}{l}4,94 \\
5,42 \\
4,55 \\
4,97 \\
4,48 \\
4,08 \\
5,53 \\
6,10 \\
5,89 \\
5,72 \\
4,90 \\
5,02 \\
4,31 \\
6,89 \\
4,25 \\
4,07 \\
4,72 \\
5,44 \\
4,09 \\
4,59 \\
6,96 \\
3,71 \\
4,17 \\
5,15 \\
3,64 \\
5,76 \\
4,65 \\
3,97 \\
3,88 \\
3,64 \\
4,51 \\
4,13\end{array}$ & $\begin{array}{l}3,51 \\
3,38 \\
3,93 \\
3,04 \\
3,36 \\
3,86 \\
3,55 \\
3,29 \\
3,31 \\
3,38 \\
2,98 \\
3,52 \\
3,06 \\
2,85 \\
4,03 \\
4,47 \\
3,58 \\
4,12 \\
3,03 \\
3,62 \\
3,99 \\
2,93 \\
3,17 \\
3,49 \\
3,21 \\
3,52 \\
3,61 \\
3,88 \\
2,54 \\
3,01 \\
2,38 \\
3,67\end{array}$ & $\begin{array}{l}2,63 \\
2,47 \\
2,38 \\
2,23 \\
2,24 \\
2,09 \\
2,58 \\
2,81 \\
2,62 \\
2,72 \\
2,17 \\
2,46 \\
2,22 \\
3,02 \\
2,17 \\
2,10 \\
2,20 \\
2,72 \\
2,00 \\
2,46 \\
3,45 \\
1,80 \\
2,18 \\
2,54 \\
1,97 \\
2,73 \\
2,34 \\
2,07 \\
2,01 \\
1,90 \\
2,18 \\
2,23\end{array}$ & $\begin{array}{l}1,22 \\
1,49 \\
1,18 \\
1,58 \\
1,24 \\
1,26 \\
1,48 \\
1,55 \\
1,48 \\
1,41 \\
1,28 \\
1,57 \\
1,56 \\
1,55 \\
1,46 \\
1,29 \\
1,56 \\
1,56 \\
1,45 \\
1,31 \\
1,93 \\
1,43 \\
1,34 \\
1,24 \\
1,32 \\
1,60 \\
1,34 \\
1,47 \\
1,44 \\
1,19 \\
1,24 \\
1,23\end{array}$ & $\begin{array}{l}0,89 \\
1,19 \\
0,91 \\
1,23 \\
1,02 \\
0,95 \\
1,15 \\
1,18 \\
1,21 \\
1,08 \\
1,26 \\
1,04 \\
0,94 \\
1,28 \\
0,96 \\
0,95 \\
1,15 \\
1,00 \\
1,05 \\
0,86 \\
1,03 \\
1,06 \\
0,91 \\
1,01 \\
0,84 \\
1,10 \\
0,98 \\
0,93 \\
0,92 \\
0,92 \\
1,06 \\
0,85\end{array}$ \\
\hline \multicolumn{7}{|l|}{$F$} \\
\hline $\begin{array}{l}\text { Tratamentos } \\
\text { Nitrogēnio (N) } \\
\text { Fösforo (P) } \\
\text { Potássio (K) } \\
\text { Calcārio dolomitico } \\
\text { (cal.) }\end{array}$ & $\begin{array}{l}1,43 \text { ns } \\
0,97 \text { ns } \\
1,18 \text { ns } \\
0,001 n s \\
2,60 \text { ns }\end{array}$ & $\begin{array}{l}1,01 \mathrm{~ns} \\
0,31 \mathrm{~ns} \\
3,19 \mathrm{~ns} \\
0,86 \mathrm{~ns} \\
1,10 \mathrm{~ns}\end{array}$ & $\begin{array}{l}1,56 \mathrm{~ns} \\
0,06 \mathrm{~ns} \\
0,77 \mathrm{~ns} \\
0,25 \mathrm{~ns} \\
1,68 \mathrm{~ns}\end{array}$ & $\begin{array}{l}0,77 \text { ns } \\
0,23 \text { ns } \\
1,94 \text { ns } \\
0,54 \text { ns } \\
0,60 \text { ns }\end{array}$ & $\begin{array}{l}1,21 \mathrm{~ns} \\
2,80 \mathrm{~ns} \\
0,77 \mathrm{~ns} \\
0,36 \mathrm{~ns} \\
1,30 \mathrm{~ns}\end{array}$ & $\begin{array}{l}1,8 n \mathrm{~ns} \\
0,15 \mathrm{~ns} \\
3,23 \mathrm{~ns} \\
0,99 \mathrm{~ns} \\
3,19 \mathrm{~ns}\end{array}$ \\
\hline 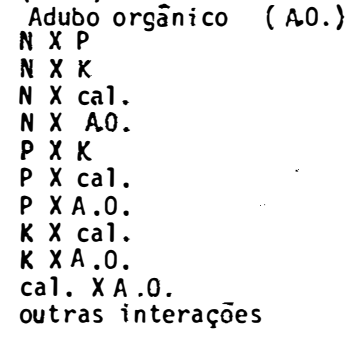 & $\begin{array}{l}0,02 \mathrm{~ns} \\
2,67 \mathrm{~ns} \\
3,21 \mathrm{~ns} \\
1,09 \mathrm{~ns} \\
2,51 \mathrm{~ns} \\
0,91 \mathrm{~ns} \\
0,30 \mathrm{~ns} \\
7,41 \star \\
3,40 \mathrm{~ns} \\
2,97 \mathrm{~ns} \\
3,75 \mathrm{~ns} \\
0,76 \mathrm{~ns}\end{array}$ & $\begin{array}{l}4,41 \star \\
0,24 \text { ns } \\
1,68 \text { ns } \\
2,58 \text { ns } \\
0,18 \text { ns } \\
1,07 \text { ns } \\
0,11 \text { ns } \\
0,002 \mathrm{~ns} \\
0,001 \mathrm{~ns} \\
1,07 \mathrm{~ns} \\
1,10 \mathrm{~ns} \\
0,89 \mathrm{~ns}\end{array}$ & $\begin{array}{l}0,03 \mathrm{~ns} \\
3,61 \mathrm{~ns} \\
7,94 \star \star \\
0,01 \mathrm{~ns} \\
3,13 \mathrm{~ns} \\
0,10 \mathrm{~ns} \\
0,005 \mathrm{~ns} \\
8,40 \star \star \\
1,10 \mathrm{~ns} \\
3,76 \mathrm{~ns} \\
2,50 \mathrm{~ns} \\
0,99 \mathrm{~ns}\end{array}$ & $\begin{array}{l}2,14 \mathrm{~ns} \\
0,18 \mathrm{~ns} \\
0,08 \mathrm{~ns} \\
1,38 \mathrm{~ns} \\
0,10 \mathrm{~ns} \\
1,24 \mathrm{~ns} \\
0,51 \mathrm{~ns} \\
0,02 \mathrm{~ns} \\
0,07 \mathrm{~ns} \\
1,77 \mathrm{~ns} \\
1,63 \mathrm{~ns} \\
0,78 \mathrm{~ns}\end{array}$ & $\begin{array}{l}0,07 \mathrm{~ns} \\
0,06 \mathrm{~ns} \\
0,91 \mathrm{~ns} \\
4,31 \star \\
0,05 \mathrm{~ns} \\
6,81 \star \\
0,54 \mathrm{~ns} \\
0,34 \mathrm{~ns} \\
3,37 \mathrm{~ns} \\
0,01 \mathrm{~ns} \\
1,66 \mathrm{~ns} \\
0,94 \mathrm{~ns}\end{array}$ & $\begin{array}{r}9,20 * \\
0,04 n \\
15,32 \\
3,64 n \\
0,09 n \\
0,02 n \\
1,57 n \\
0,003 n \\
1,54 n \\
0,48 n \\
0,67 n \\
1,13 n\end{array}$ \\
\hline $\begin{array}{l}\text { Mēdia geral } \\
\text { C.V. }\left(\begin{array}{c}\% \\
\left({ }^{2}\right.\end{array}\right.\end{array}$ & $\begin{array}{r}8,26 \\
18,55\end{array}$ & $\begin{array}{r}4,82 \\
25,69\end{array}$ & $\begin{array}{r}3,41 \\
15,24\end{array}$ & $\begin{array}{r}2,36 \\
24,08\end{array}$ & $\begin{array}{r}1,41 \\
14,92\end{array}$ & $\begin{array}{r}1,03 \\
12,64\end{array}$ \\
\hline
\end{tabular}

observações: $n s=$ não significativo a $5 \%$ de probabilidade; ${ }^{*}=$ $=$ significativo a $5 \%$ de probabilidade; ${ }^{* *}=$ significativo a $1 \%$ de probabilidade. 
Tabela 23. Médias e intervalos de variação de relações entre teores de nutrientes de folhas de gra ma-batatais em diferentes tratamentos e em duas coletas (dezembro de 1981 e abril de 1982).

\begin{tabular}{|c|c|c|c|}
\hline $\begin{array}{l}\text { Relações entre teores } \\
\text { de nutrientes na maté } \\
\text { ria seca de folhas }\end{array}$ & Coletas & Média geral & Intervalos de variaçāo \\
\hline N/P & $\stackrel{1}{a}$ & $\begin{array}{l}11,50 \\
19,85\end{array}$ & $\begin{array}{rr}6,80- & 20,00 \\
10,77- & 31,67\end{array}$ \\
\hline$N / K$ & $\begin{array}{l}1 \mathrm{a} \\
2 \stackrel{\mathrm{a}}{\mathrm{a}}\end{array}$ & $\begin{array}{l}1,21 \\
1,05\end{array}$ & $\begin{array}{ll}0,75- & 1,83 \\
0,76- & 1,46\end{array}$ \\
\hline N/S & $\begin{array}{l}1 \mathrm{a} \\
2 \stackrel{\mathrm{a}}{\mathrm{a}}\end{array}$ & $\begin{array}{l}13,36 \\
13,06\end{array}$ & $\begin{array}{ll}7,00- & 20,00 \\
8,24- & 18,57\end{array}$ \\
\hline $\mathrm{P} / \mathrm{Ca}$ & $\begin{array}{l}1 \mathrm{a} \cdot \\
2 !\end{array}$ & $\begin{array}{l}0,62 \\
0,26\end{array}$ & $\begin{array}{ll}0,29- & 0,93 \\
0,16- & 0,46\end{array}$ \\
\hline $\mathrm{P} / \mathrm{Mg}$ & $\begin{array}{l}1 \stackrel{a}{a} \\
2 \stackrel{a}{:}\end{array}$ & $\begin{array}{l}0,86 \\
0,26\end{array}$ & $\begin{array}{ll}0,32- & 1,17 \\
0,16- & 0,52\end{array}$ \\
\hline$P / S$ & $\begin{array}{l}1 \stackrel{\mathrm{a}}{\mathrm{a}} \\
2 \stackrel{\mathrm{a}}{\cdot}\end{array}$ & $\begin{array}{l}1,18 \\
0,68\end{array}$ & $\begin{array}{ll}0,80- & 1,77 \\
0,46- & 1,43\end{array}$ \\
\hline $\mathrm{P} / \mathrm{Fe}$ & $\begin{array}{l}1 \cdot a \\
2 \stackrel{a}{a}\end{array}$ & $\begin{array}{r}20,00 \\
2,43\end{array}$ & $\begin{array}{lr}4,78- & 51,16 \\
0,72- & 6,80\end{array}$ \\
\hline$P / 2 n$ & $\begin{array}{l}1 \stackrel{\mathrm{a}}{\mathrm{a}} \\
2 \stackrel{\mathrm{a}}{\mathrm{e}}\end{array}$ & $\begin{array}{l}96,70 \\
68,04\end{array}$ & $\begin{array}{l}40,00-158,83 \\
27,27-109,09\end{array}$ \\
\hline $\mathrm{K} / \mathrm{Ca}$ & $\begin{array}{l}1 \stackrel{\mathrm{a}}{\mathrm{a}} \\
2 \stackrel{\mathrm{a}}{.}\end{array}$ & $\begin{array}{l}5,87 \\
4,70\end{array}$ & $\begin{array}{ll}2,80- & 9,03 \\
3,17- & 9,18\end{array}$ \\
\hline $\mathrm{K} / \mathrm{B}$ & $2^{\mathrm{a}}$ & $\begin{array}{r}1152,64 \\
596,40\end{array}$ & $\begin{array}{l}569,23-3920,00 \\
412,12-1006,66\end{array}$ \\
\hline $\mathrm{Ca} / \mathrm{B}$ & $\begin{array}{l}1 \stackrel{a}{a} \\
2 !\end{array}$ & $\begin{array}{l}197,04 \\
129,29\end{array}$ & $\begin{array}{r}110,00-680,00 \\
70,97-253,33\end{array}$ \\
\hline $\mathrm{Fe} / \mathrm{Mn}$ & $\begin{array}{l}1 \stackrel{a}{a} \\
2 \stackrel{a}{.}\end{array}$ & $\begin{array}{l}1,01 \\
4,91\end{array}$ & $\begin{array}{rr}0,50- & 2,63 \\
1,73- & 10,14\end{array}$ \\
\hline $2 n / C u$ & $\begin{array}{l}19 \\
2 \stackrel{a}{a}\end{array}$ & $\begin{array}{l}1,79 \\
1,78\end{array}$ & $\begin{array}{l}0,82- \\
1,10-\end{array}$ \\
\hline $2 \mathrm{n} / \mathrm{Fe}$ & ${ }^{1} \stackrel{\mathrm{a}}{\mathrm{a}}$ & $\begin{array}{l}0,19 \\
0,04\end{array}$ & $\begin{array}{ll}0,09- & 0,41 \\
0,01- & 0,08\end{array}$ \\
\hline $2 n / M n$ & $1^{\mathrm{a}}$ & $\begin{array}{l}0,18 \\
0,15\end{array}$ & $\begin{array}{ll}0,13- & 0,23 \\
0,10- & 0,27\end{array}$ \\
\hline
\end{tabular}


Tabela 24. Médias e intervalos de variaçao de rela ções entre teores de nutrientes de semen tes de grama-batatais em diferentes tratamentos e em duas coletas (dezembro de 1981 e abril de 1982).

\begin{tabular}{|c|c|c|c|}
\hline $\begin{array}{l}\text { Relações entre teores } \\
\text { de nutrientes na matế } \\
\text { ria seca de sementes }\end{array}$ & Coletas & Média geral & Intervalos de varíaçāo \\
\hline$N / P$ & $\stackrel{1}{a}^{\mathrm{a}}$ & $\begin{array}{l}6,02 \\
8,89\end{array}$ & $\begin{array}{r}4,10-8,67 \\
5,26-12,70\end{array}$ \\
\hline$N / K$ & $l^{\mathrm{a}}$ & $\begin{array}{l}5,04 \\
7,64\end{array}$ & $\begin{array}{rr}4,03-5,91 \\
4,74-\quad 14,28\end{array}$ \\
\hline$N / S$ & $1^{a}$ & $\begin{array}{l}12,94 \\
12,52\end{array}$ & $\begin{array}{l}7,59-18,57 \\
7,69-25,00\end{array}$ \\
\hline $\mathrm{P} / \mathrm{Ca}$ & $2^{a} \cdot$ & $\begin{array}{l}4,00 \\
2,44\end{array}$ & $\begin{array}{l}1,50-6,00 \\
1,67-4,75\end{array}$ \\
\hline $\mathrm{P} / \mathrm{Mg}$ & $\begin{array}{l}i^{\mathrm{a}} \\
2 \stackrel{\mathrm{a}}{0}\end{array}$ & $\begin{array}{l}2,98 \\
1,80\end{array}$ & $\begin{array}{ll}2,12- & 5,50 \\
1,43- & 4,75\end{array}$ \\
\hline$P / S$ & $\begin{array}{l}1^{\mathrm{a}} \\
2^{\mathrm{a}}\end{array}$ & $\begin{array}{l}2,19 \\
1,45\end{array}$ & $\begin{array}{ll}1,35- & 3,71 \\
1,08- & 4,75\end{array}$ \\
\hline $\mathrm{P} / \mathrm{Fe}$ & $i^{a}$ & $\begin{array}{l}15,80 \\
14,36\end{array}$ & $\begin{array}{l}9,19-25,49 \\
7,69-38,00\end{array}$ \\
\hline$P / Z n$ & $\begin{array}{l}l_{a}^{a} \\
2 \cdot\end{array}$ & $\begin{array}{l}69,80 \\
50,01\end{array}$ & $\begin{array}{l}44,19-96,30 \\
40,00-111,76\end{array}$ \\
\hline $\mathrm{K} / \mathrm{Ca}$ & $\stackrel{1}{a}^{a}$ & $\begin{array}{l}4,80 \\
2,86\end{array}$ & $\begin{array}{l}2,30-7,75 \\
1,75-4,60\end{array}$ \\
\hline $\mathrm{K} / \mathrm{Mg}$ & $\begin{array}{l}1 \stackrel{a}{a} \\
2 !\end{array}$ & $\begin{array}{l}3,50 \\
2,08\end{array}$ & $\begin{array}{l}2,88-4,75 \\
1,62-\quad 2,88\end{array}$ \\
\hline $\mathrm{K} / \mathrm{Ca}+\mathrm{Mg}$ & $\begin{array}{l}1 \stackrel{a}{a} \\
2 \stackrel{a}{a}\end{array}$ & $\begin{array}{l}2,00 \\
1,20\end{array}$ & $\begin{array}{ll}1,35- & 2,82 \\
0,88- & 1,54\end{array}$ \\
\hline $\mathrm{k} / 8$ & $2^{a}$ & $\begin{array}{r}121,34 \\
60,64\end{array}$ & $\begin{array}{l}59,09-520,00 \\
30,56-105,26\end{array}$ \\
\hline $\mathrm{Ca} / \mathrm{Hg}$ & $\begin{array}{l}1 \mathfrak{a} \\
2 !\end{array}$ & $\begin{array}{l}0,77 \\
0,74\end{array}$ & $\begin{array}{ll}0,44- & 1,43 \\
0,57- & 1,00\end{array}$ \\
\hline $\mathrm{Ca} / 8$ & $l^{\mathrm{a}}$ & $\begin{array}{l}26,28 \\
21,37\end{array}$ & $\begin{array}{l}11,36-120,00 \\
11,11-36,84\end{array}$ \\
\hline $\mathrm{Fe} / \mathrm{Mn}$ & $\begin{array}{l}1^{\mathrm{a}} \\
2 \stackrel{\mathrm{a}}{.}\end{array}$ & $\begin{array}{l}5,85 \\
3,59\end{array}$ & $\begin{array}{l}3,59-12,00 \\
1,93-11,77\end{array}$ \\
\hline $2 n / C u$ & $\stackrel{1^{a}}{a}$ & $\begin{array}{l}3,91 \\
2,62\end{array}$ & $\begin{array}{ll}2,31- & 7,00 \\
1,57- & 5,62\end{array}$ \\
\hline $2 n / F e$ & $\begin{array}{l}1 \mathrm{a} \\
2 \mathrm{a}\end{array}$ & $\begin{array}{l}0,23 \\
0,29\end{array}$ & $\begin{array}{l}0,14-0,40 \\
0,14-0,43\end{array}$ \\
\hline $\mathrm{Zn} / \mathrm{Mn}$ & $\begin{array}{l}19 \\
2 \mathrm{a}\end{array}$ & $\begin{array}{l}1,29 \\
1,00\end{array}$ & $\begin{array}{l}0,91-\quad 1,89 \\
0,60-3,46\end{array}$ \\
\hline
\end{tabular}




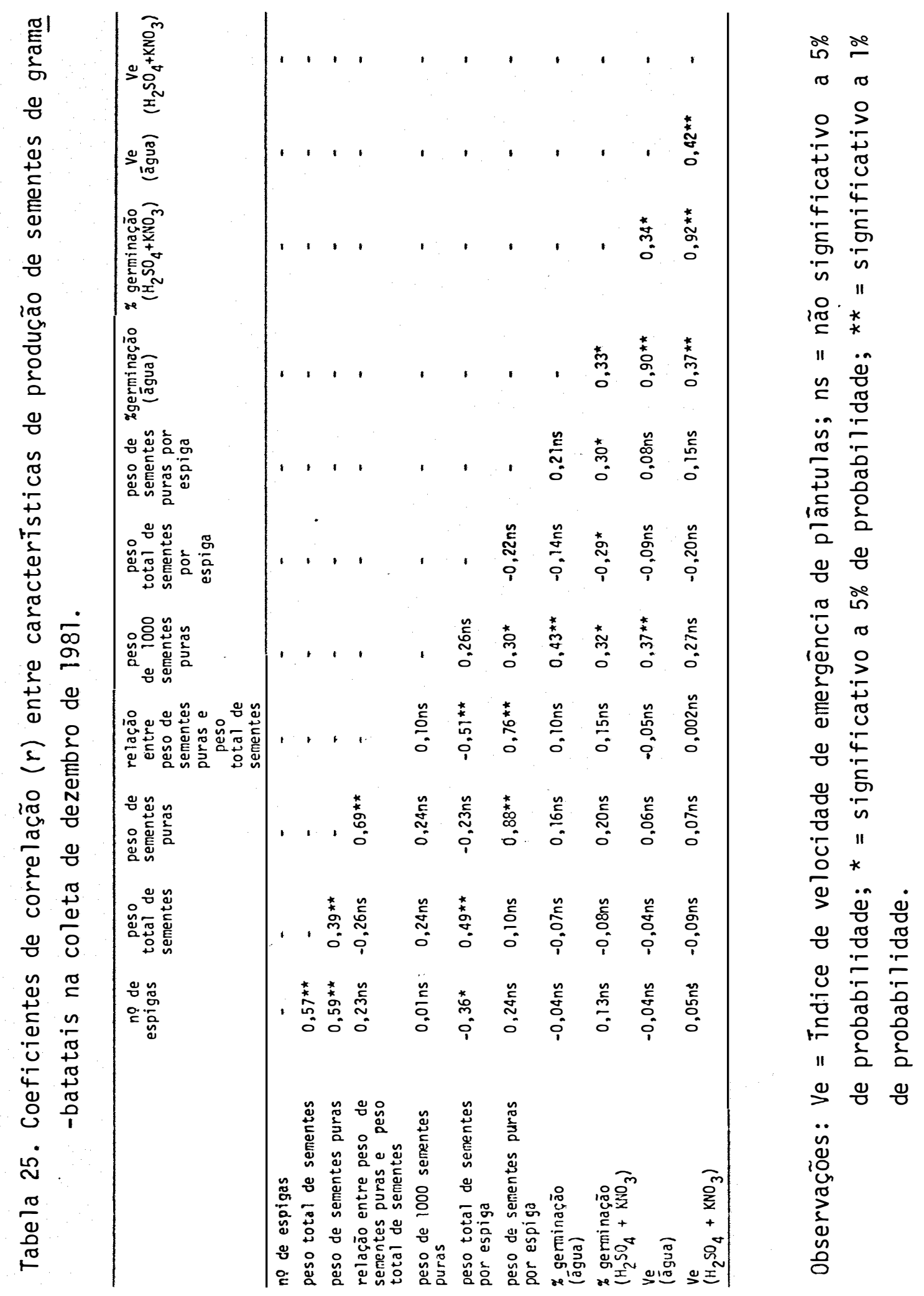




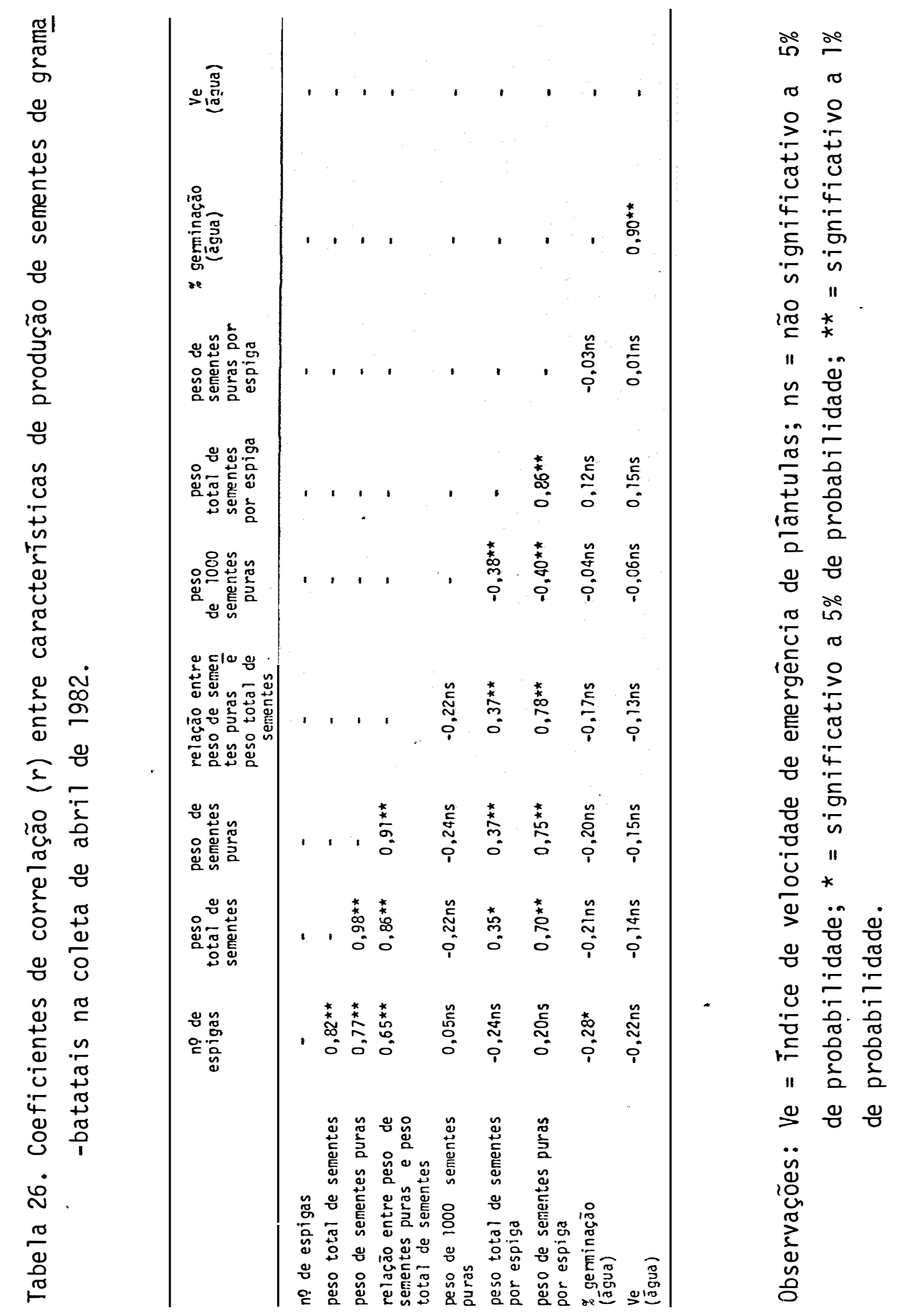




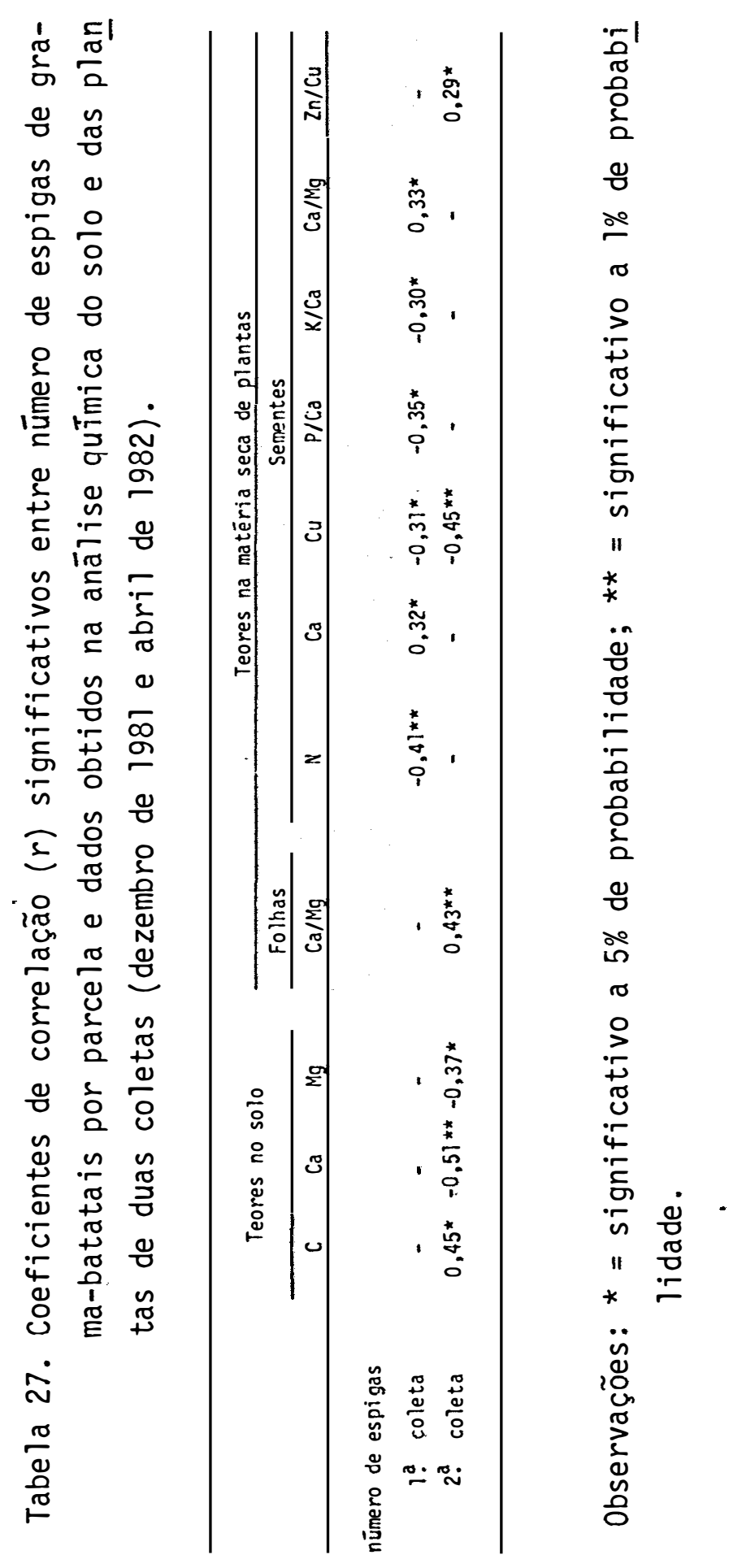




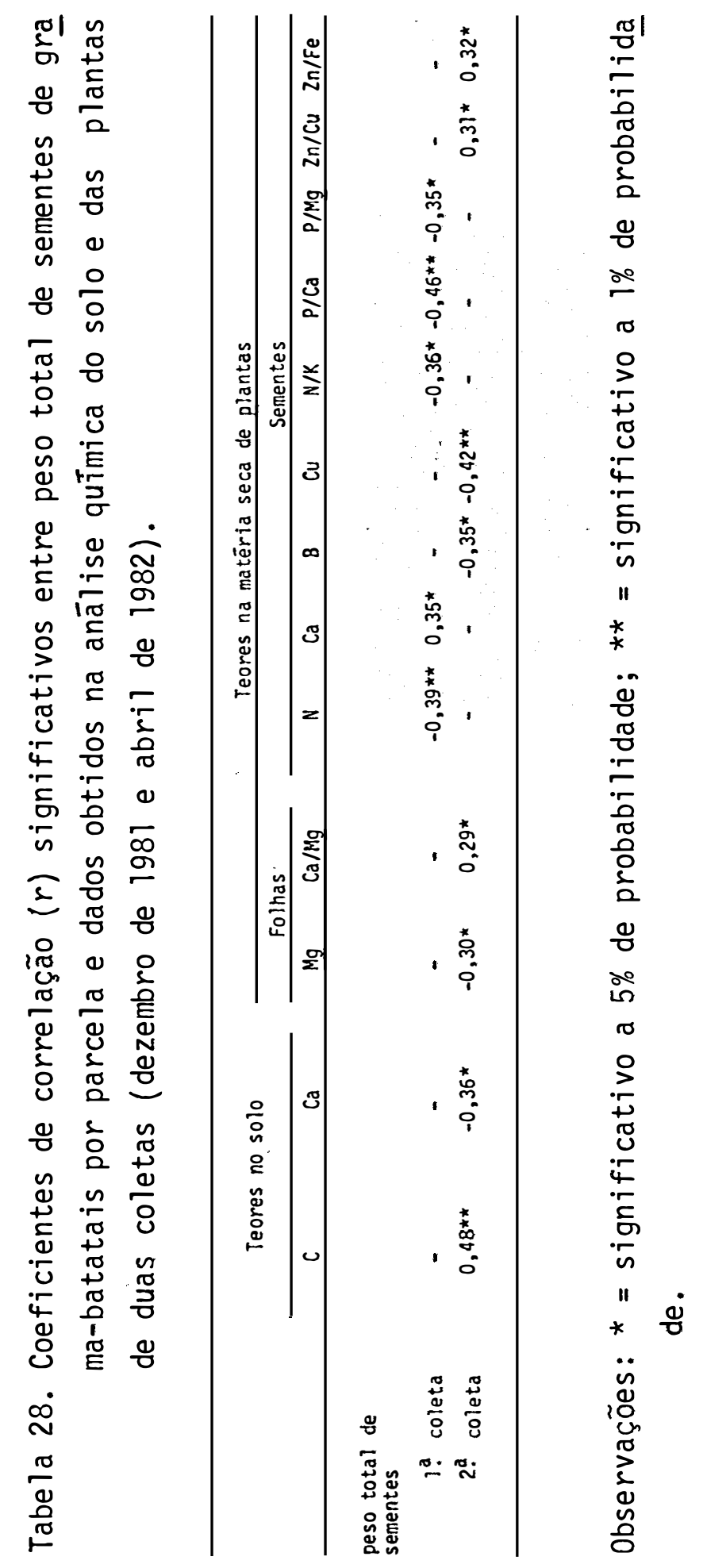




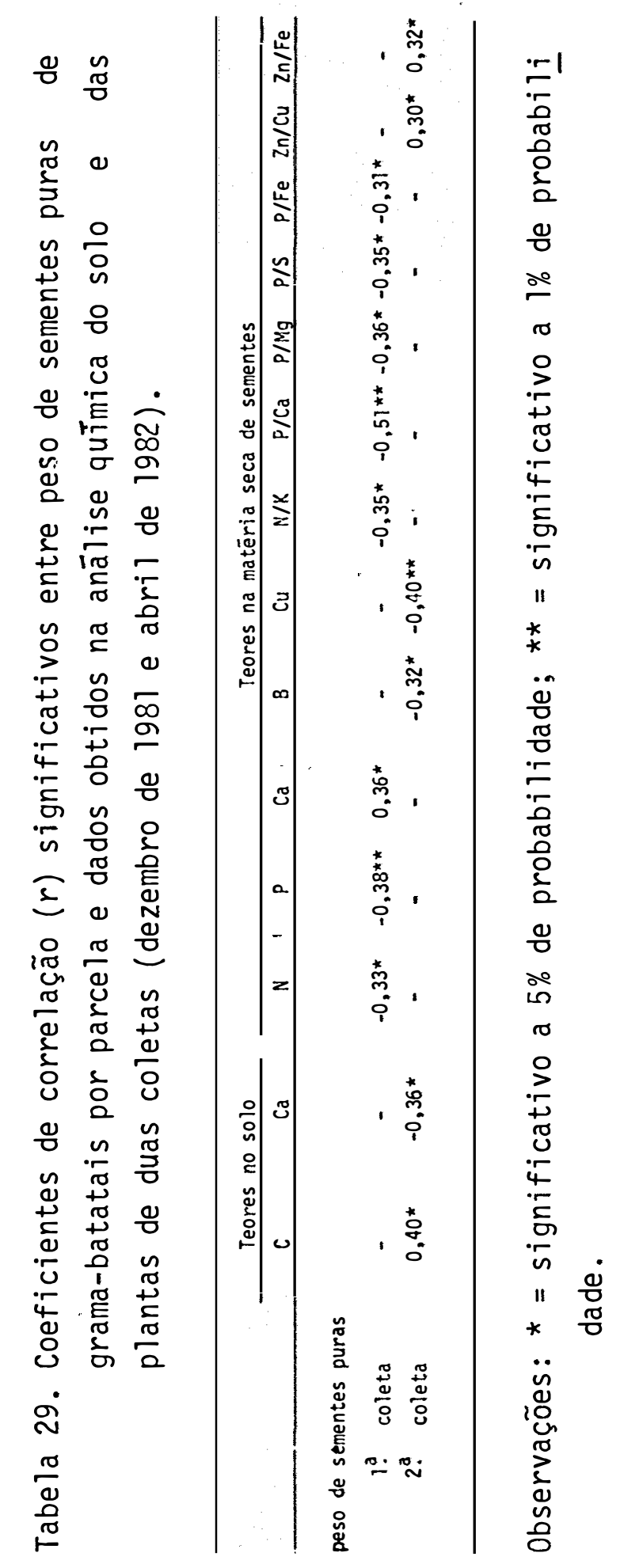




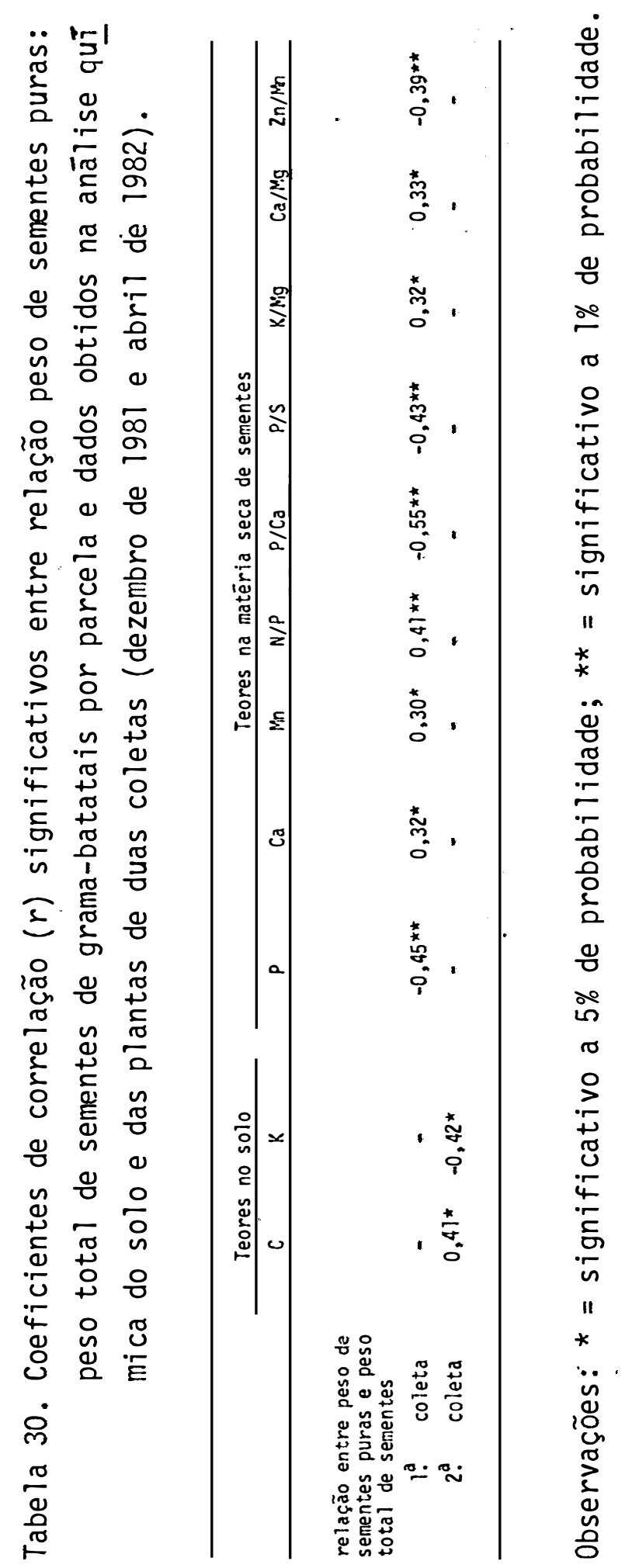




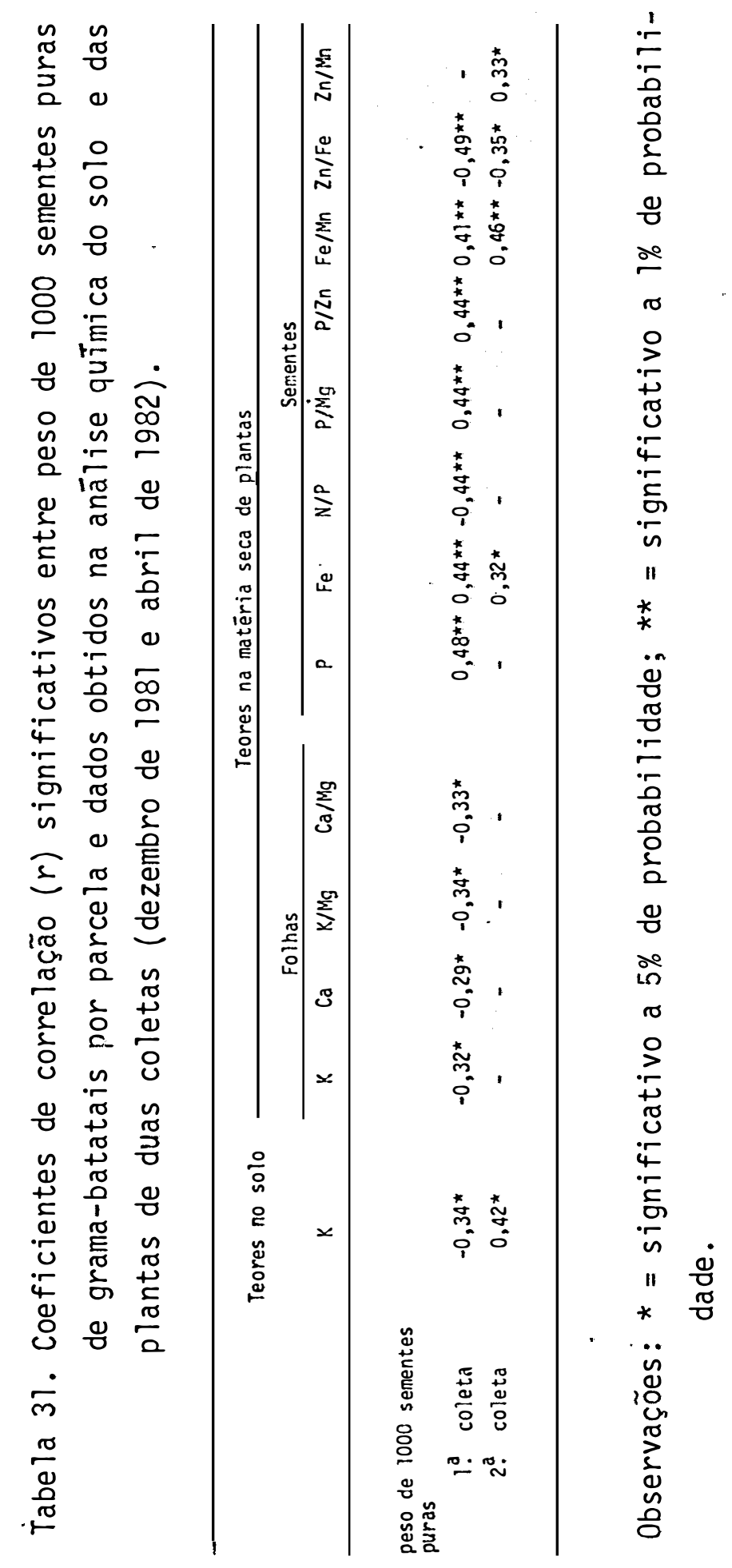




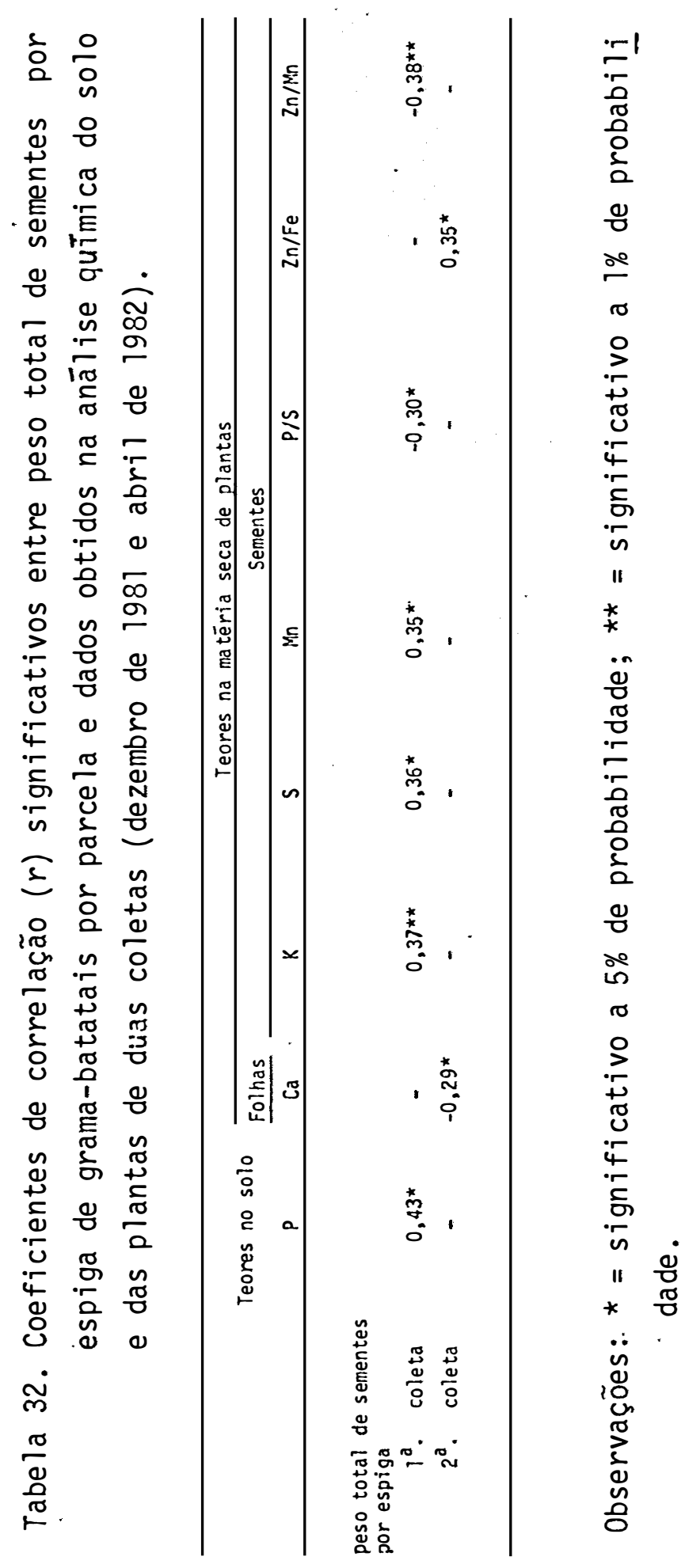




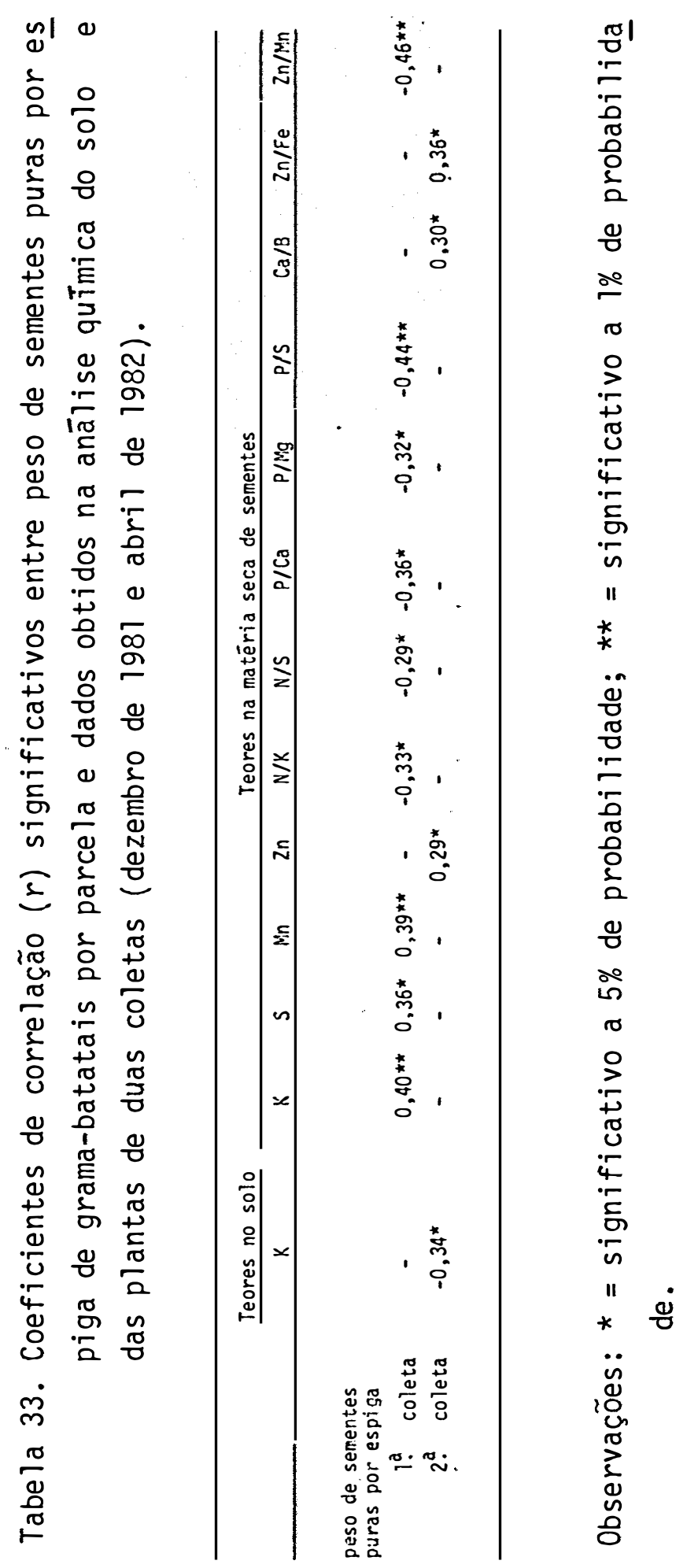




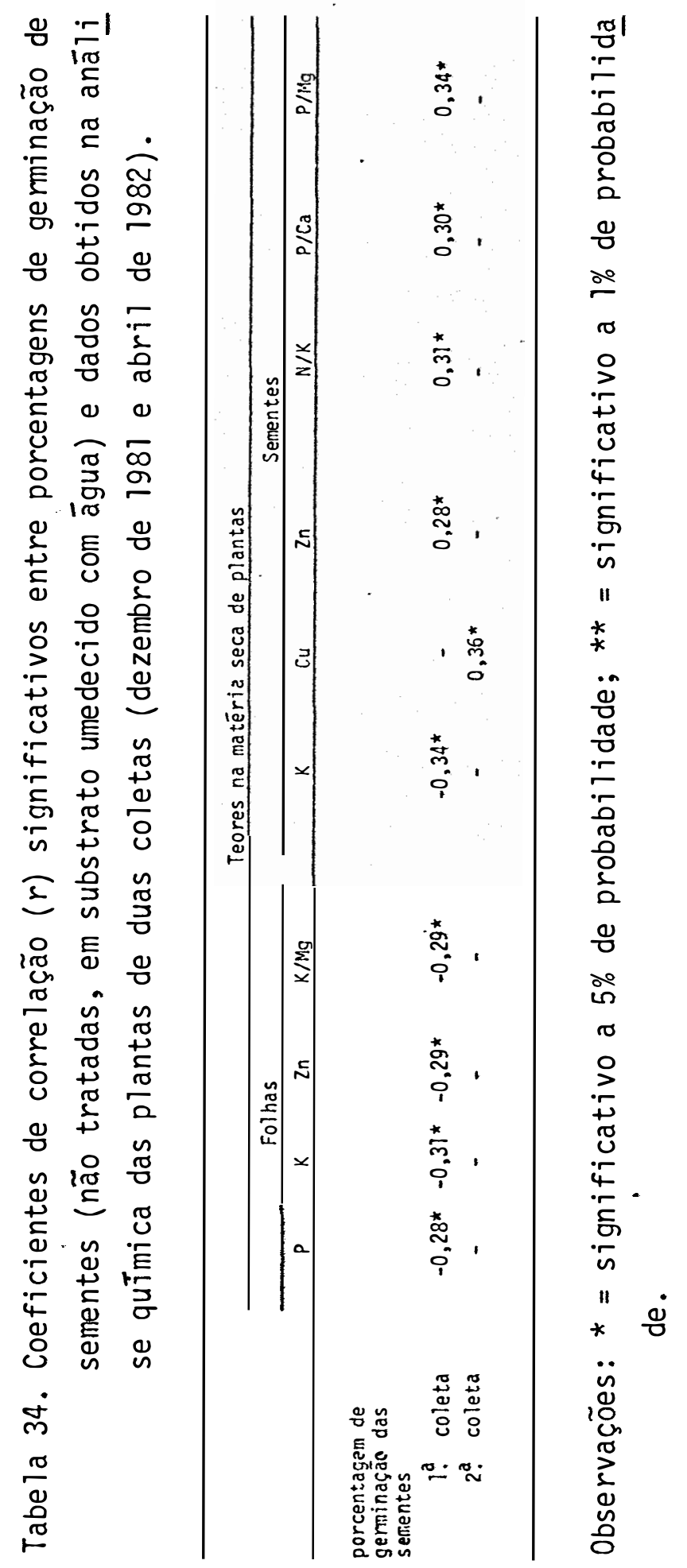




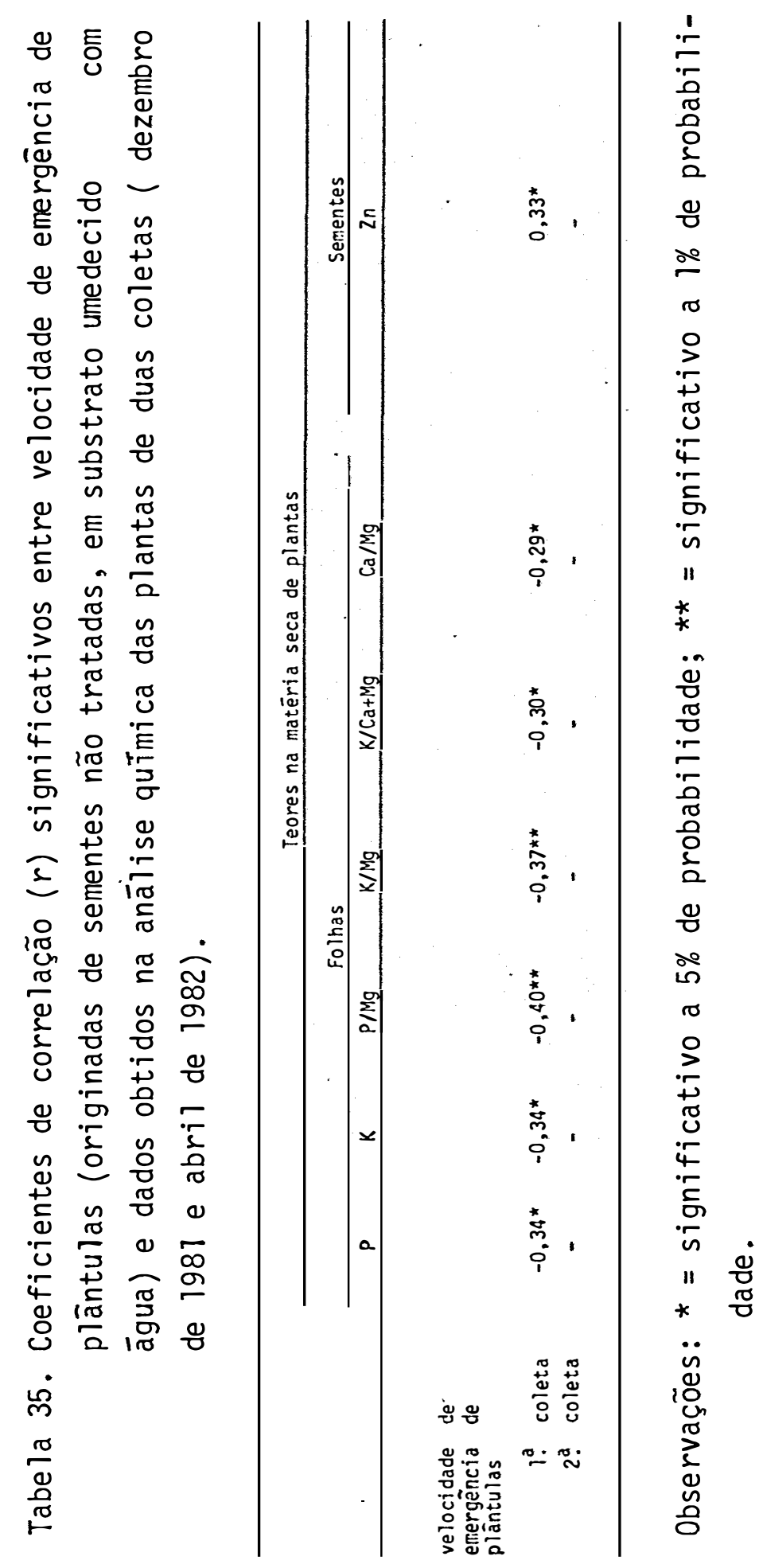




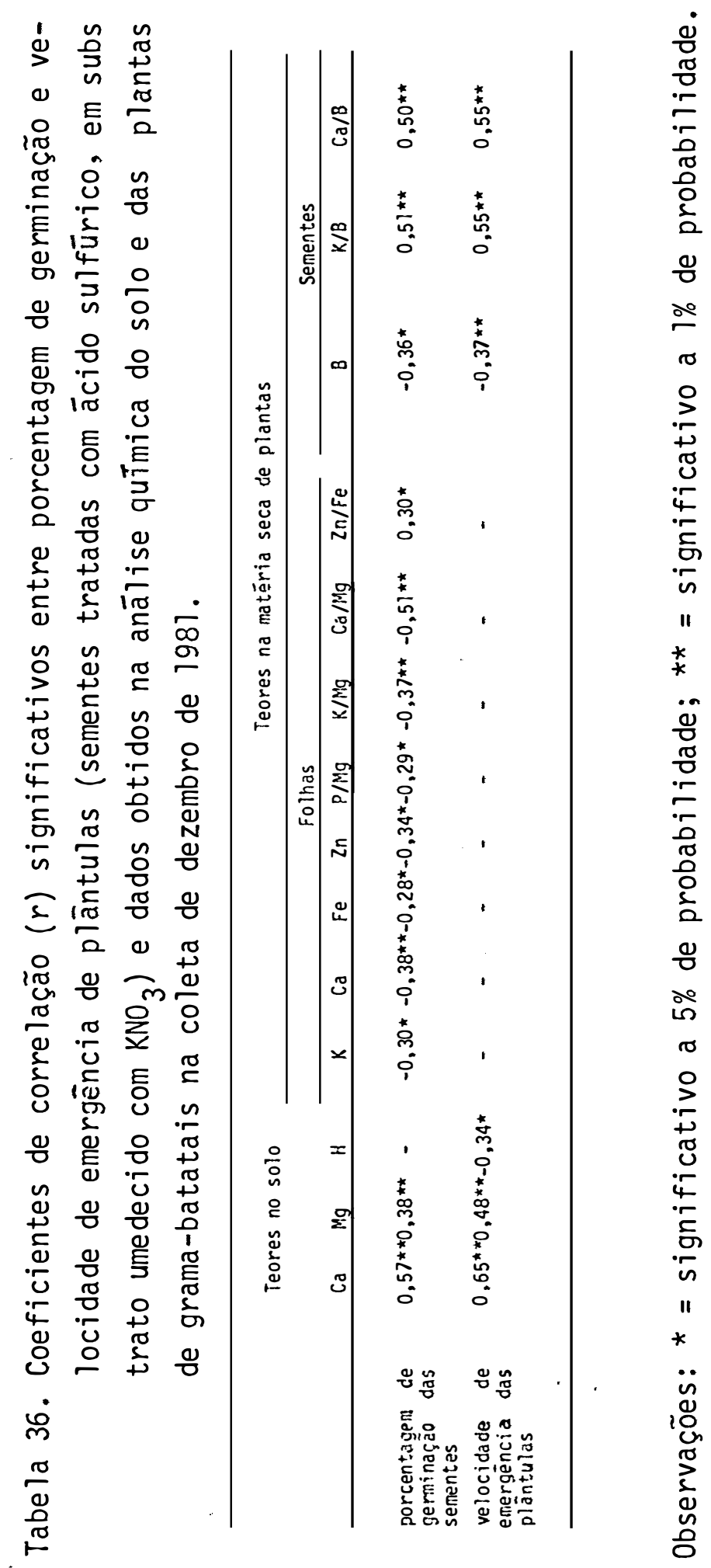

